\title{
Lifeline Electric Rates and Alternative Approaches to the Problems of Low-Income Ratepayers
}

\section{Ten Case Studies of Rejected Programs}

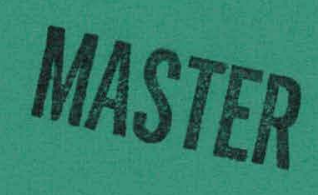

July 1980

Prepared for:

U.S. Department of Energy

Economic Regulatory Administration

Office of Utility Systems

Under Contract No. AC01-79RG10066 


\section{DISCLAIMER}

This report was prepared as an account of work sponsored by an agency of the United States Government. Neither the United States Government nor any agency Thereof, nor any of their employees, makes any warranty, express or implied, or assumes any legal liability or responsibility for the accuracy, completeness, or usefulness of any information, apparatus, product, or process disclosed, or represents that its use would not infringe privately owned rights. Reference herein to any specific commercial product, process, or service by trade name, trademark, manufacturer, or otherwise does not necessarily constitute or imply its endorsement, recommendation, or favoring by the United States Government or any agency thereof. The views and opinions of authors expressed herein do not necessarily state or reflect those of the United States Government or any agency thereof. 


\section{DISCLAIMER}

Portions of this document may be illegible in electronic image products. Images are produced from the best available original document. 


\section{NOTICE}

This report was prepared as an account of work sponsored by the United States Government. Neither the United States nor the United States Department of Energy, nor any of their employees, makes any warranty, express or implied, or assumes any legal liability or responsibility for the accuracy, completeness, or usefulness of any information, apparatus, product, or process disclosed, or represents that its use would not infringe privately owned rights. Reference herein to any specific commercial product, process, or service by trade name, mark, manufacturer, or otherwise, does not necessarily constitute or imply its endorsement, recommendation, or favoring by the United States Government or any agency thereof. The views and opinions of authors expressed herein do not necessarily state or reflect those of the United States Government or any agency thereof.

Avallable from:

National Technical Information Service (NIIS)

U.S. Department of Commerce

5285 Port Royal Road

Springfield, Virginia 2216

Price: Printed Copy :

Microfiche:

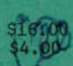


DOE/RG/10066-03

Volume 3 of 3 Volumes

Dist. Category UC-97

\section{Lifeline Electric Rates and Alternative Approaches to the Problems of Low-Income Ratepayers: \\ Ten Case Studies of Rejected Programs}

July 1980

Prepared for: U.S. Department of Energy

Economic Regulatory Administration Office of Utility Systems

Washington, D.C. 20461

Prepared by:

Cleveland State University

College of Urban Affairs, Energy Program

Cleveland, Ohio 44115

Under Contract No. AC01-79RG10066
This book was prepared as an account of work sponsored by an agency of the United States Government. Neither the United Stales Government nor Bny ogency thereot, nor any of their employees, makes any

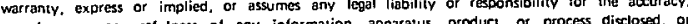
completeness, ar us whes represens nat meceserily constiture or imply its endorsement, recommendation, or tavaring by the United States Government or any agency thereof. The views and opinions of authors expressed herein do not necessarily state or reflect those of the United States Government or any agency thereot. 
Volume 3

TABLE OF CONTENTS

Page

LIST OF TABLES . . . . . . . . . . . . . . . . . . i ii

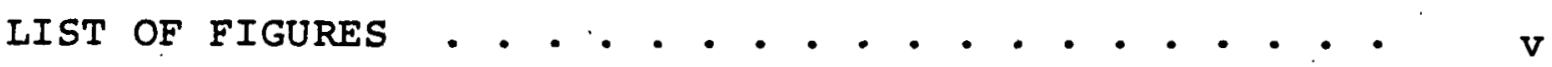

Section

I. DELAWARE SENATE BILI 202 . . . . . . . . . . 1

Program summary . . . . . . . . . . . . 1

Issue Development . . . . . . . . . . . . 6

Governmental Process . . . . . . . . . . 12

Impact . . . . . . . . . . . . . . . . 19

II. ILLINOIS HOUSE BILL 83. . . . . . . . . . . . 27

Program Summary . . . . . . . . . . . . 27

Issue Development and the Governmental
Process . . . . . . . . . . . . . . 29

Impact . . . . . . . . . . . . . . . . . . 34

III. MAINE LEGISLATIVE DOCUMENT NO. 1043 . . . . . 47

Program Summary . . . . . . . . . . . . 47

Issue Development . . . . . . . . . . . . 49

The Governmental Process . . . . . . . . 57

Impact... . . . . . . . . . . . . 62

IV. MINNESOTA HOUSE FILE 1243 . . . . . . . . . . 70

Program Summary . . . . . . . . . . . . 71

The Governmental Process . . . . . . . . 73

Impact . . . . . . . . . . . . . . . . 77 
V. NEW YORK ASSEMBLY BILL 12214 . . . . . . . 81

Program Summary . . . . . . . . . . . 81

Issue Development . . . . . . . . . . . 85

The Governmental Process . .. . . . . . . 90

Impact . . . . . . . . . . . . . . . 94

VI. NEW YORK SENATE BILL 7013-A . . . . . . . . 83

Program Summary . . . . . . . . . . . 83

Issue Development . . . . . . . . . 85

The Governmental Process . . . . . . . 90

Impact. . . . . . . . . . . . . . 102

VII. RHODE ISLAND RESOLUTION 79-H 5770-A . .. .113

Program Summary . . . . . . . . . . . 113

Issue Development . . . . . . . . . . 114

The Governmental Process . . . . . . . . . 122

Impact . . . . . . . . . . . . . . . 125

VIII. SOUTH DAKOTA SENATE JOINT RESOLUTION 9 • • • 135

Program Summary . . . . . . . . . . . 135

Issue Development and the Governmental

Impact . . . . . . . . . . . . . 141

IX. WEST VIRGINIA HOUSE BILL 943 . . . . . . 147

Program Sumiary :. . . . . . . . . . 147

Issúe Development .. . . . . . . . . 149

The Governmental Process . . . . . . . 153

Impact. . . . . . . . . . . . . . . . 156

X. WISCONSIN ASSEMBLY BIIL 1250 . . . . . . . 167

Program Summary . . . . . . . . . . 167

Issue Development . . . . . ... . . 169

The Governmental Process . . . . . . . . 174

Impact .. . . . . . . . . . . . . . 179 


\author{
Volume 3
}

\title{
LIST OF TABLES
}

Table

Page

I Calculation of Bencfit Levels Under Delaware Senate Bill 202 . . . . . . . . . . . . 23

II Týpical Residential Electric Bills for Consumers of Four Utility Companies (Illinois) as Percent of Income (at $607 \mathrm{kwh} / \mathrm{month}$ ) ... . 35

II Residential Electric Bills for Consumers of Four Illinois Utility Companies as Percent of Iricome (at $500 \mathrm{kwh} / \mathrm{month}$ ) . . . . . . 35

IV Residential Bill Comparison . . . . . . . . 38

$V \quad$ Immediate Impact of $\mathrm{HB} 83$ Using 1977 Revenues as Base . . . . . . . . . . . . . . . . .

VI Estimates of Anticipated Effects of Lifeline

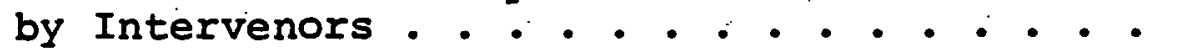

VII Comparison of Lifeline and Actual Rates . • . 66

VIII Typical Energy Bills from Minnesota Power and Light and Northern States Power . . . . . 79

IX Percentage of Family Income Spent on Electricity in New York State . . . . . . . . 95

X Census Data Relating to Electricity use in New York State 1970 . . . . . . . . . 96

XI Household Income of Sample Population . . . . 103

XII Owner/Renter Status of Sample Population (By \&) 
Table

Page

XIII Energy Sources Used for Heating Comparison of Survey Sample of Low-Income Elderly with State Energy Office Figures for all Socioeconomic Groups .". . . . . . . . . 106

XIV Comparison of Living Cost. Increases Over One-Year and Four-Year Periods (as Percentages) .............. 108

XV Average Monthly Electricity Consumption by

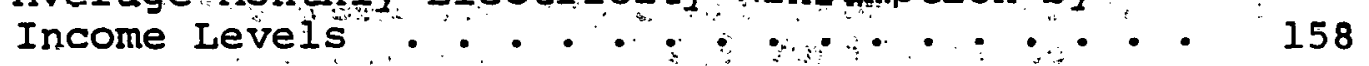

XVI Comparison Between Low-Income Customer Annual usage and Totál Company Annual Residential Usage ............ . 161

XVII Monangahela power co. . . . . . . . . 162

XVIII Appalachian Power Co. . . . . . . . . 162

XIX Percentage of Income spent on Electric Bills ................. 181

XX Typical Levels of Summer Electric Usage . • 182

XXI Relative Frequency Distributions of Electricity Usage by Wisconsin and Household Income Levels for all Cities served by Wisconsin Power and Light Company . . . . 183

XXII Estimated Shortfall--Uniroyal . . . .... 187

XXIII Wisconsin Power and light Estimates of SB 122 (Lifeline Rate) Impact on Industrial Customers . . . . . . . . 188

XXIV Wisconsin Power and Light Estimates of SB 122 (Lifeline Rate) Impact on Commercial Customers 


\section{Volume 3}

\section{IIST OF FIGURES}

Figure

Page

1 Delmarva Power and Light. Co. Residential Rates in Effect 9/29/78 . . . . . . . . .

2 Delmarva Power and Light Co. Commercial/ Industrial Capacity Charge . . . . . . . . .

3 "Iifeline" (HB 83) Effect on Customers' Electric Energy Use . . . . . . . . . .

4 Legislative Activity on Central Lifeline Options, 1976-1979.............. 
DELAWARE SENATE BILL 202

\section{Program Summary}

Delaware Senate Bill 202 (SB 202) proposed an inverted residential rate schedule of:

-- $3 \xi / \mathrm{kwh}$ for the first $400 \mathrm{kwh}$;

-- $4 \xi / \mathrm{kwh}$ for the next $400 \mathrm{kwh}$;

-- $5 \% / \mathrm{kwh}$ for usage in excess of $800 \mathrm{kwh} / \mathrm{month}$.

Revenue recovery was not specifically addressed in the bill.

These rates were to apply to all residential customers in single-family dwellings and individually metered apartments. The proposed rates and the rates in effect in September of 1978 are compared in Figure 1 .

The residential rate in effect in 1977 was the traditional declining block structure with five blocks. Although the form was traditional, the actual rate for the first two blocks were exceptionally high at over $20 \% / \mathrm{kwh}$ for the first $15 \mathrm{kwh}$ and $11 \mathrm{k} / \mathrm{kwh}$ for the next $30 \mathrm{kwh} / \mathrm{month}$. 


\section{Figure 1}

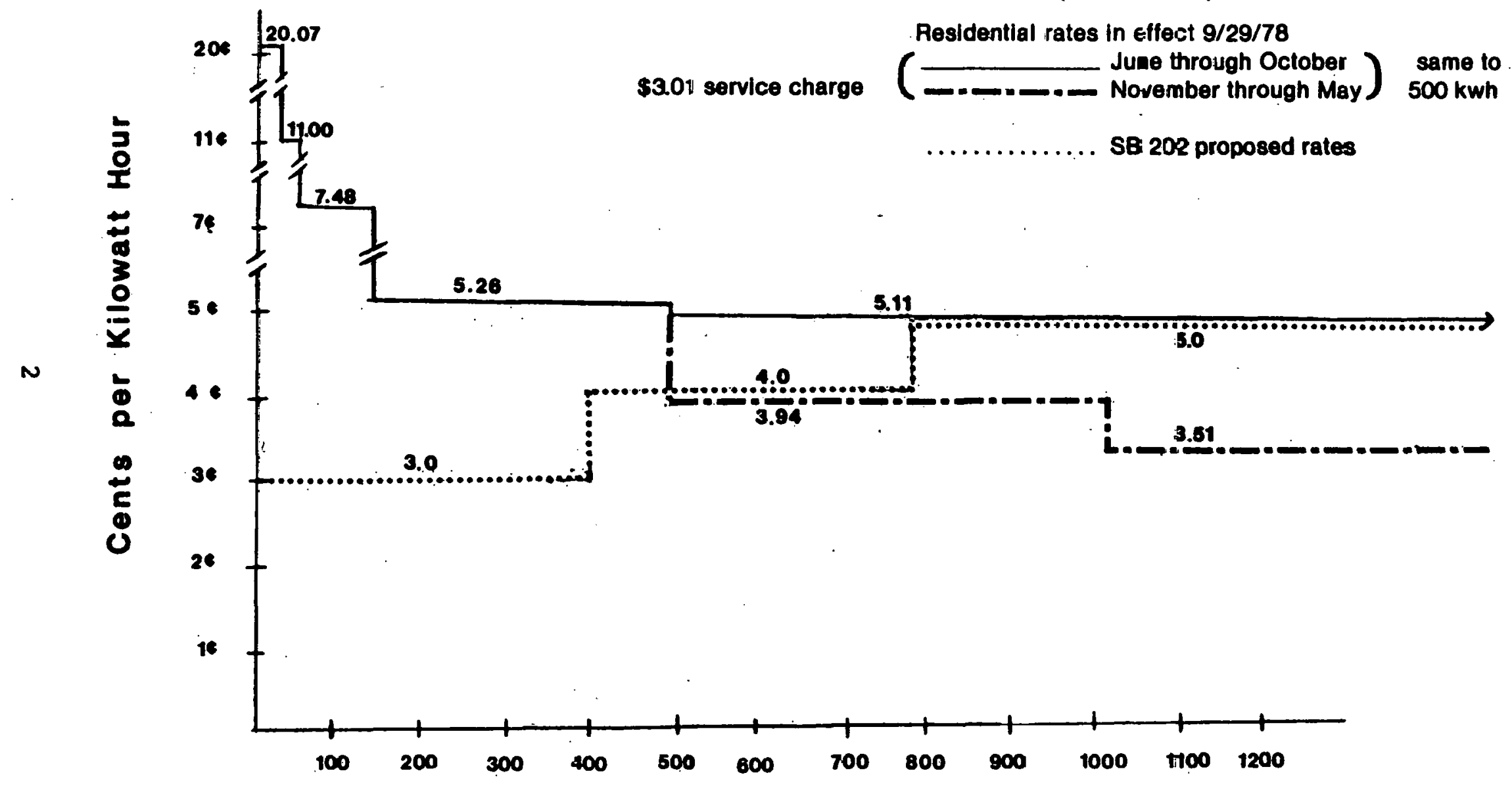

Kilowatt Hours per Month 
The proposed rate described above was, obviously, drastically lower.

The bill also set a specific rate for commercial and industrial customers. Peak rates were a flat $3 \xi / \mathrm{kwh}$ and off-peak rates were $2 \xi / \mathrm{kwh}$. Added to the kwh charge was a service charge of $\$ 2.50$ per month and a capacity, charge. The proposed capacity charge and the capacity. charge in effect in September of 1978 are compared in Figure 2. As can be readily seen; the capacity charge was increased significantly by SB 202: the increase varied from approximately $\$ 1.50 / \mathrm{kw}$ at the front end of the schedule to an increase of over $\$ 5.50 / \mathrm{kw}$ for usage in excess of 20,000 kw.

other provisions in the bill included:

-- Residences in conjunction with commercial or industrial enterprises; homes or dormitories for groups; apartment buildings; and mobile homes in courts may take service under the prescribed rates only under terms and conditions established by the utility company;

-- Rates for farm use were set at $4 \xi / \mathrm{kwh}$, regardless of monthly usage.

Industrial/commercial and farm service customers were required to pay a service charge while regular residential customers were not. Fuel adjustment charges were applied to regular residential and farm service bills but not to industrial/commercial bills.

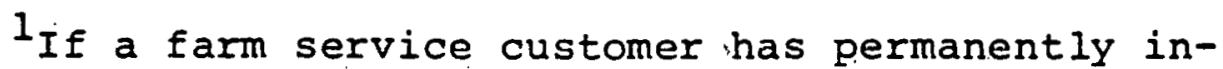
stalled electric space heating equipment, the $4 \mathrm{k} / \mathrm{kwh}$ would only apply to the first $4,000 \mathrm{kwh} / \mathrm{month}$. Usage in excess of this amount would be billed at $5 \mathrm{k} / \mathrm{kwh}$. (the same as the tail block for regular residential customers). 


\section{Figure 2}

\section{DELMARVA POWER AND LIGHT COMPANY}

Commercial/Incustrlal Capacity Charge

Actual (as of $9 / 29 / 78$ )

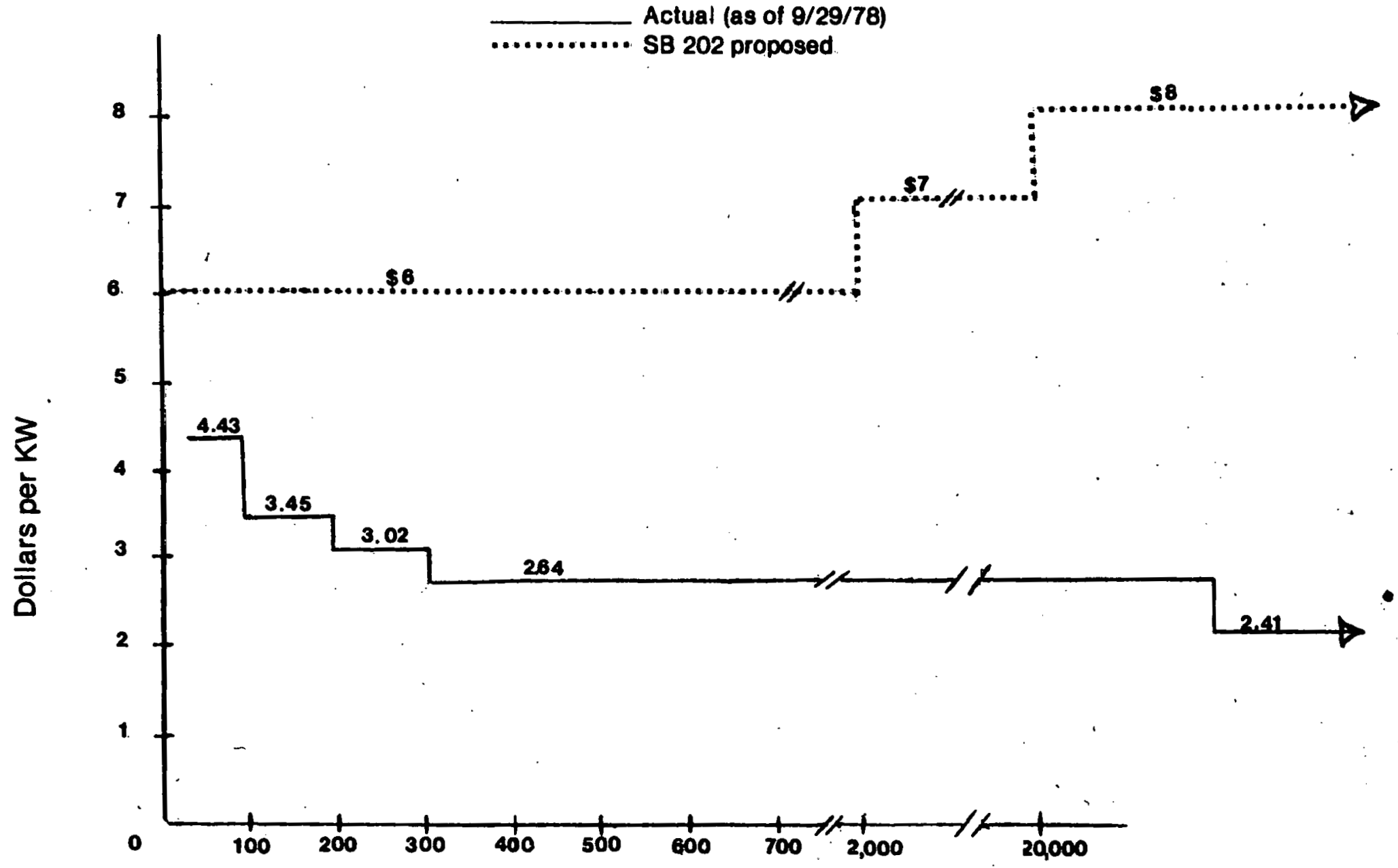

$\mathrm{KW}$ per month 
The rates specified by this bill could be revised by the Public Service Commission (PSC); however, the bill stated that "[n]o rate increase . . . shall be valid if it does not conform to the relationships between rate blocks, and to the ratios between rates as set forth (in the bill)."

The General Assembly was also given the authority to nullify rate increases that may have been allowed by the PSC. 
Issue Devel noment

Major Actors and Events Prior to Topic Legislation

The Citizens Coalition for Tax Reform (CCTR) was organized in 1973 by consumer activist Ted Keller. The group has been actively involved in protecting consumer interests, especially in the areas of state tax and utility rate reform. Keller has intervened in the last two rate cases heard before the Public Service Commission, in 1977 and 1978 .

In both instances the Delmarva Power and Light Company (DP\&L) ${ }^{2}$ had requested increases that, if combined, according to Keller, would have raised the average residential electric bill by 488 within a 13 -month period. The Commission did grant the entire 1977 rate increase request ${ }^{3}$ but successful consumer intervention in the 1978 case resulted in the company being awarded only one-quarter of the

${ }^{2}$ Largest electric utility, in the state, provides 928 of Delaware's electricity.

${ }^{3}$ Docket No. 885, Order August 1977. 
request. 4 Keller called this "the first win for consumers." He explained that consumers received the benefits of expert testimony for the first time during this rate case: the CCTR experts had found flaws in the DP\&I cost-of-service calculations and the Commission granted only $\$ 8$ million of a requested $\$ 33$ milition increase.

This "first win" was due to the creation of the Office of the Public Advocate (PA) in July, 1978, through senate Bill 643. The Public Advocate represents the consumer before the commission, and the office is funded through general appropriations. Evan Wilner, the first PA, is currently involved as a consumer intervenor in Phase II of the generic DP\&L rate case Docket No. 923 .

The Delmarva Power Company has consistently opposed lifeline rates in testimony before the commission, the legislature, and to DP\&I customers. The Company Policy statement Against Lifeline asserts that:

Underprivileged citizens and citizens with fixed incomes have problems for which society must provide assistance. . . . If a lifeline bill were enacted by the Delaware state Legislature, it would set a very bad precedent for determining prices by legislative means and on the basis of social considerations [Emphasis added] :

This statement is echoed by several large industrial companies which were contacted for this case study. A spokesman for Dupont Chemical, whose corporate headquarters are in Delaware, says that they have opposed the lifeline concept through its membership activities in the Electricity Consumers Resource Council (ELCON). This.

${ }^{4}$ Docket No. 923, Phase I (revenue requirement) Order, November, 1978 . 
national organization opposes lifeline rates because it believes that while industry will suffer first if lifeline rates are adopted and volume discounts are eliminated, prices ultimately will go up for everyone.

It would appear that consumer action, through the direct support of the CCTR and through the newly-created Public Advocate, and continued legislative pressure in the form of lifeline proposals every year since 1976 have kept the lifeline issue alive in Delaware. Anti-lifeline forces, most notably DP\&L, have shown equal persistence and stamina; however, according to Public Advocate Wilner, 1980 will see the lifeline concept "take a back burner" to other pressing "big business inequities."

\section{Other Assistance Programs}

The Delaware Energy Crisis Assistance Program was enacted through legislation ${ }^{5}$ and is administered by the Delaware Energy Office. The program provides vendor credit payments for current heating bills of needy households ${ }^{6}$ to a maximum annual, one-time amount of $\$ 200$. It supplements the federal crisis assistance program by raising eligibility to $140 \%$ of poverty and, further, allows for a $\$ 200$ maximum per household loan for payment of current heating bilis to households whose income is above 1508 of poverty. The loans are at 0-18 interest and can be forgiven on a onefor-two ratio for the expenditure of energy conservation improvements. This combined grant and loan assistance program is funded by a $\$ 1.4$ million appropriation, with

182).

${ }^{5}$ Senate Bill No. 449, passed February 1, 1980 (62-

${ }^{6}$ Households with incomes between $125 \%$ and $150 \%$ of Community Service Administration (CSA) poverty line. 
crisis assistance monies not expended by June 30, 1980, transferring to the state Weatherization Program.

The Energy Conservation Grants (Weatherization) Program ${ }^{7}$ provides for reimbursement of one-half of the cost of selected home weatherizing materials ${ }^{8}$ to households with income levels no greater than 2008 of CSA poverty guidelines. A sum of $\$ 1.7$ million appropriated from the General Fund will implement the program through June 30, 1981.

Finaliy, Delmarva states in its 1979 Annual Report that "more than 26,000 residents of Delmarva Peninsula have received energy conservation tips through Project Conserve, a computerized home energy audit which also promotes energy efficiency."

\section{Additional Considerations}

Preferential Treatment: Unlike various other Public Utility Commissions discussed in this report, the Delaware PSC has not attempted to order the implementation of any lifeline-type rate program for the utilities under its jurisdiction. All lifeline activities have been generated through the legislature, since 1976.

In 1975, the Commission sought the opinion of the state Attorney General (AG) concerning the scope of its rate-making powers. The state law governing the regulatory powers of the commission forbids "any undue or unreasonable

7 House Bill 681, passed February 15, 1980 (62-199).

8 Insulation, weatherstripping, caulking, day/night thermostats, and any other materials that are so designated by the Energy Office. 
preference or advantage to any person or corporation" 9 by any public utility. The Commission was specifically interested to learn if "ability to pay" might be an appropriate consideration, since so many consumers appeared to be unable to pay utility bills that were a result of "cost-to-serve" determinations. The AG replied that the PUC must. set rates based on the cost of service, unless otherwise authorized by the legislature. 10

A year-long study, ordered by the Commission and conducted by Associated Utility Services to analyze DP\&I demand and forecasts, recommended that lifeline not be adopted. If the Commission were forced to adopt it, the consultants recommended that it be made available to all customers.

\section{PURPA Considerations}

With Delmarva being the sole investor-owned, regulated utility in the state, each Delmarva rate case is considered to be generic in nature. In the case currently before the Commission, II the revenue requirement phase has been completed and Phase II, which will take up PURPA issues, is underway. The length and complexity of consideration has caused a division of the hearings into phases. Phase II has even been further subdivided: PURPA Section 111 standards will be considered first, followed by section 113 regulatory standards and section 114 lifeline determination.

${ }^{9} 26$ Del. C. 1953, Section 161.

${ }^{10}$ According to the Executive Director of the PUC, the Commission staff has made no recommendations nor taken a position concerning lifeline.

${ }^{11}$ Docket No. 923 . 
Oil Backout Plans

According to a company spokesman, Delmarva's rates

are the third highest in the nation due to the fact that $57 \%$ of the company's generating fuel mix. is oil. Future plans are to increase the nuclear generation of electricity from 78 to approximately $25 \%$ and reduce dependence on oil to less than 108. 
Governmental Process

Previous Lifeline Legislature Proposals

House Bill 1127, Delaware Lifeline Utilities Act, 1976: Sponsored by Harris McDowell, the "Iifeline Senator," the bill was assigned to the Energy Committee where it died. A summary of the bill discusses its contents:

This Act proposes one of the more popular versions of the well-known "lifeline" concept. The basic premise of the Act is that light and heat are basic human rights which are to be made available to all people and not denied to some because of price structures which favor certain corporate:users, while placing the financial burden of this favored status on residential users. Under this Act there is to be a determination of the "minimum energy needs of the average residential user," which shall assist the Public service commission in its energy allocation and rate differential decisions.

This Act would direct the P.S.C. to require utilities supplying electricity to file a revised schedule of rates and charges providing a lifeline rate. It would prohibit any increase in the lifeline rate until the rates for all customers of electrical service exceed the iifeline rate by $25 \%$ or more, and would require the Commission thereafter to maintain a lifeline rate differential of at least $25 \% .12$

${ }^{12}$ Source: Synopsis, House Bill 215, April 5, 1977, p. 2 . 
House Bill 215, Delaware Lifeline Electric Utilities Act: This bill was a re-introduction of the previous year's lifeline legislation. It was assigned to the Administrative Service Committee on April 5, 1977 immediately after introduction: no further action was taken and it was considered dead at the end of the session on June 30,1977 .

It must be noted that neither of these (identical) bills specifically provided for recovery of revenue shortfall caused by the lifeline program. The proposals are modeled after the Miller-Warren Act which established California's lifeline in 1975.13 They differ from Miller-Warren in two basic respects: the bills apply only to electricity, and they contain no revenue recovery mechanism.

Subsequent Lifeline Legislative Proposals

Senate Bill 58, Lifeline Utilities Service, was introduced by its sponsor Senator McDowell on May 10, 1978 . According to a Legislative Assistant, after a long debate, the bill was finally assigned to McDowell's Administrative Services Committee where it was "pigeonholed."

This proposal is also based on Miller-Warren but to a much greater extent than previous legislation. It creates a residential lifeline rate for both electricity and gas reflecting the energy costs effective as of January 1, 1976 (as per California). Subsequent rate increases cannot be authorized until the rates for all customer classes exceed the established rate by 258. "Thereafter, in establishing electrical and gas rates, the Commission shall maintain a

${ }^{13}$ Refer to California case study for a thorough description of this model in operation. 
Iifeline rate differential of at least $25 \%, 14$

As with previous lifeline legislation, a specific revenue recovery method. was not addressed. A synopsis printed on the bill reports:

The cost of lifeline would be minimal. The only "cost" of Lifeline is in reduced revenues to the utilities from small users. What lifeline does is redistribute the cost of electricity so that large commercial and industrial users pay their fair share. In the long run, Lifeline" saves everybody money because it encourages conservation which, in turn, diminishes the need to expand expensive generating facilities.15

In testimony before the Delaware General Assembly concerning S.B. 588, DP\&L Vice President Earl D. Krapf objected to the lifeline concept:

The function of a utility is to provide service on a non-discriminatory basis through rate schedules that are cost-based. There is no way to justify a Lifeline Rate from a purely cost-oriented standpoint.

These losses in revenue would have to be made up by other . . "customers.

The testimony concludes:

Legislatures should not evade their own respunsibilities for the general welfare, however they perceive it, by singling the privately-owned utility industry out of the overall economy to perform a social service.

Topic Legislation: Senate Bill 202, Delaware Energy Lifeline Act, 1977

When a utility company begins to file for aramatic rate increases on an annual basis, when energy shortages and costs begin to seriously affect peoples' lives and

\section{${ }^{14}$ Senate Bill 588, Section 3, May 10, 1978. \\ 15 Refer to Program Impact section of California} Iifeline Program case study for a thorough evaluation of shortfall costs and problems. 
jobs, when the company seems unable to muster the ability to prevent these things or analyze its real problems, other solutions, such as "lifeline," must be attempted.

Harris B. McDowell III

Legislative Activity

S.B. 202 was introduced in the General Assembly on May 4, 1977 by its joint sponsors, Senator McDowell and Representative Ambrosino. It was assigned that day to the Energy Committee, which McDowell chairs, and a series of public hearings were held on the bill in June. According to a News-Journal report, there was considerable support for lifeline, unlike the previous year. "Even Governor Pierre $S$. DuPont IV has said he supports the concept, although he warned that legislation would have to be worked out and drawn up very carefully to make it feasible."16 The public debate over lifeline and SB 202 was characterized by the newspaper as "lively but deeply divided," with consumer representatives arguing for the bill and business and DP\&I spokesmen arguing against it.

The bill was reported out of committee on June 27 , 1977 with the following results: one favorable vote, two votes recommending further action on its merit, and two unfavorable votes. Sent on to the senate, it was amended to clarify the language defining "farm use" and to correct an apparent typographical error concerning the commercial or industrial energy charge. 17

On June 29, 1977, the amended bill was introduced

$$
\begin{aligned}
& 16 \text { News-Journal, June } 3,1977, \mathrm{p} .3 \\
& 17 \text { From } \$ 2.00 \text { to } \$ .02 \text { and from } \$ 3.00 \text { to } \$ .03 \text {. }
\end{aligned}
$$


and passed the Senate. A roll call vote was requested on the bill but, due to insufficient votes, the roll call was tabled. The following day was the close of the legislative session, and the bill died.

Comparison of Lifeline Legislative Attempts

The thrust of lifeline in Delaware from its emergence as an issue in 1975 has beén solely the result of legislative activity. The Comission was not permitted to mandate any change in the rate structure that was not proven cost-justified without being granted the authority to so act by the legislature. Legislators such as McDowell and Ambrosino repeatedly attempted to insert lifeline language into the Delaware General Code but were never successful. This failure was largely due to active and organized opposition from the business sector and DP\&L.

Unlike some other states which specifically confined a lifeline program to the residential class, the ambiguity in Delaware lifeline proposals concerning shortfall recovery apparently posed a severe threat to large users. Since most proposals were labeled "based on California," commercial and industrial customers could foresee what might happen to their rates by looking at what was happening to businesses' energy costs out west. Business spokesmen testified that such increases in electric rates could possibly force permanent plant closings.

Senate Bill 202 differed from the previous and subsequent lifeline proposals in a number of respects, but the major difference concerned the problem of revenue recovery. The other bills would have established a discount for small users within the residential class, but made no provision 
for recouping the losses caused by this discount. Iifeline advocates appeared to ignore the fact that regulated utilities were guaranteed a certain revenue by law: shortfall could not merely be absorbed by the company. Lifeline opponents feared that the revenue burden would be unfairly placed on them.

SB 202 would have dramatically altered the entire rate profile of every class of customer, from a declining block profile to an inverted one. A graph comparing the residential rates ${ }^{18}$ shows a sizable discount up to $800 \mathrm{kwh}$ with a very slight increase for usage over that amount. The commercial and industrial rates, however, would be more than doubled under the proposed new rates. This obviously was to be the implicit recovery mechanism. ${ }^{19}$

This bill, then, dealt with the mafor lifellne problem of shortfall in a most direct manner. Interestingly enough, by its explicit language it effectively would remove much of the Commission's authority to set rates. First, the bill itself completely restructures the profiles of almost every rate classification ${ }^{20}$ and lists the charges to be applied. Second, although it allows the PUC "the power and authority to change residential, commercial and industrial rates," it stipulates that the General Assembly may ". . nullify such rate increases. No rate

\section{${ }^{18}$ Refer to Figure 1.}

${ }^{19} \mathrm{~A}$ thorough description of the program's impact is discussed in the next section of this case study.

20 Apartments and other master-metered dwellings "may take service on the (residential) rate only under the terms and conditions set forth by the energy supplier." 
increase, however, shall be valid if it does not conform to the relationships between rate blocks and to the ratios between rates as set forth in . . . this chapter." In effect, then, the Legislature would become the watchdog of the Commission, with the power to overrule Commission orders which deviate from the intent of this bill by means of a simple resolution.

The specificity of this proposal and its implications if adopted make, it a most unusual example of lifeline legislation, and appears as though the specificity of the bill may have been the reason, for the volatile activity which surrounded it, eventually causing its defeat. 
Impact

The intended beneficiariés of Delaware SB 202 were residential consumers who used "relatively small quantities of electricity."

In the service area of Delmarva Power and Light, 21 it was estimated by the campany in 1979 that 95,000 residential customers out of a total of 149,000 residential customers use less than $700 \mathrm{kwh} / \mathrm{month}$ and could be classified as small users. In other words, approximately 648 of DP\&L's residential electric customers are small users.

The graph of the rate, 22 however, shows that lifeline benefits will accrue to users of less than $500 \mathrm{kwh} /$ month on the winter schedule (November to May); while usage in excess of $500 \mathrm{kwh}$ would be cheaper on the regular, nonlifeline residential rate. The summer (June-October) lifeline rates are cheaper across the board than the regular rates for usage of any level.

${ }^{21}$ Whose electric division delivers 928 of Delaware's electric energy needs.

22 Refer to Figure 1. 
Thus it would appear that, although the legislation specifically states the purpose of the Act is "to provide a basic necessary amount of gas ${ }^{23}$ and electricity for residential heating and lighting at a cost which is fair to small users," lifeline benefits are gained for all residential users on the summer schedule and for usage under $500 \mathrm{kwh} /$ month on the winter schedule. Somewhat less than $648.0 \mathrm{f}$ winter-rate residential customers, therefore, are beneficiaries and 1008 of summer-rate residential customers' would appear to benefit from the inverted rates.

A profile of the state population includes the following: 8.68 elderly; 8.28 low income; and over 708 urban. Approximately 548 of all low-income households in Delaware were classified "in extreme need" 24 for the 1977-78 heating season. The percentage of households which are mastermetered is not available and it is not known if mastermetered households, which include many poor households, would benefit from the proposed program. 25

\section{Need Assessment}

The majority of the population heat with fuel oil or gas and use electricity for non-heat purposes. The average annual kwh consumption per residential customer was 7,825 or $652 \mathrm{kwh} /$ month. ${ }^{26}$ Based on. DP\&L summer (1978)

${ }^{23}$ Not covered under the bill, however.

${ }^{24}$ Required to spend $25 \%$ or more of income for heating or total energy expenditures.

${ }^{25}$ It is up to the company to supply the terms and rates for this group; what actions might have been taken can only be speculated.

${ }^{26}$ Source: Edison Electric Institute, Statistical Yearbook, 1977 . 
rates, such usage would cost that customer $\$ 40.34$, plus the applicable electric fuel adjustment clause. This electric bill would represent $3.2 \%$ of monthly income for a family with a moderate annual income of $\$ 15,000$. A low-income family of four earning $\$ 8,000$ and using $500 \mathrm{kwh} / \mathrm{month}$ would have an electric bili of $\$ 32.57$, representing $4.9 \%$ of their monthly income. If this poor family consumed the average residential amount of $652 \mathrm{kwh} / \mathrm{month}$, their electric bill. would constitute $6 z$ of monthly income, or approximately $\$ 40$.

Based on average residential usäge data provided by DP\&L, a discount offered on monthly electric usage under $700 \mathrm{kwh}$ would appear to satisfy the needs of the majority of electric consumers, including low-income small users. since the poor spend a greater percentage of their disposable income for electricity than do moderate income households, they naturally will accrue greater benefits from any discount. A program such as that proposed by SB 20.2 would have offered enhanced benefits because the $\$ 3.01$ service charge ( 7.58 of the monthly bill) was to have been forgiven.

\section{Targeting Effectiveness}

As mentioned, $63 \%$ of DP\&L's residential customers limit electric usage to under $700 \mathrm{kwh} /$ month, 27 but only those customers who consumed less than $500 \mathrm{kwh} /$ month would benefit from the proposed lifeline rate between November and May of each year. Usage of any amount would be cheaper for all residential customers during the months of June through October. ${ }^{28}$

\section{month.}

27 With average statewide usage pegged at $653 \mathrm{kwh} /$

${ }^{28}$ As compared against DP\&I 1978 (current) rates. 
The program's explicit target group of residential small users is quite broad in scope, as it appears to apply to the majority of residential customers. Through the bill's assertion that heat and light are basic human rights, the program is also implicitly targeted to fixed and other low-income households. The implicit target group can be expressed as approximately 47,000 persons, ${ }^{29}$ many of whom Iive in master-metered situations and, as noted, may not have benefitted from the program.

Calculation of Benefit Levels

The bill provides for an inverted rate for the residential, commercial/industrial, farm, and farm with electric heat classes. The benefits are targeted to the residential class, and represent a substantial savings over the current rate. This is due to the fact that the proposed inverted residential rate is priced significantly lower overall than the current declining block rate. 30

A comparison of typical bilis under both rates illustrates projected savings levels. Based on Table I, the electric bill of small users would be reduced from between $33 \%$ - $51 \%$ for usage under $800 \mathrm{kwh} / \mathrm{month}$. Savings, in some measure, would accrue to virtuaily all residential customers for almost any level of usage. Obviously, the proposed. lifeline discount would represent significant savings, which would not be decreased by any service, customer, or minimum charges.

A low-income family of four using $500 \mathrm{kwh}$ would

${ }^{29}$ U.S. Bureau of the Census. Current Population Reports, Consumer Income, Money Income and Poverty Status in 1975 of Families and Persons in the United States by Division of States. Series P-60. March, 1978 .

${ }^{30}$ Refer to Figure 1. 
save approximately $2.5 \%$ of their monthly disposable income of $\$ 667$; a one-person, low-income household using 500 kwh/ month would save $4.7 \%$ of the maximum 1979 HEW poverty guideline annual figure of $\$ 4,250$, or $\$ 354$ per month.

\section{TABLE I}

CAICULATION OF BENEFIT LEVELS UNDER DELAWARE SENATE BILL 202

\begin{tabular}{ccccccc}
\hline & \multicolumn{2}{c}{ Monthly Bill } & & \multicolumn{2}{c}{ Savings } \\
\cline { 2 - 3 } $\begin{array}{c}\text { KWH Monthly } \\
\text { Usage }\end{array}$ & Lifeline & Actual $(S / \mathrm{W}) *$ & & Summer & Winter \\
\hline 200 & $\$ 6.00$ & $\$$ & 16.79 & & $\$$ & 10.79 \\
500 & 16.00 & 32.57 & & 16.57 \\
800 & 28.00 & $47.90 / 44.39$ & & 19.90 & 16.39 \\
1,000 & 38.00 & $58.12 / 52.27$ & & 20.12 & 14.27 \\
1,500 & 63.00 & $83.67 / 69.82$ & & 20.67 & 6.82 \\
\hline
\end{tabular}

*Includes DP\&L minimum charge of $\$ 3.01$

\section{Revenue Recovery}

The proposal structured inverted rates for the commercial and industrial classes which were significantly higher than the current rates for these classes. The revenues generated from these greatly increased commercial/ industrial rates would appear to more than cover the (unspecified) residential shortfall.

Typical or average bills are not available for commercial or industrial customers and therefore comparisons of the proposed vs. the actual rates cannot be made; however, as was shown in Figure 2, one component of industrial/ commercial rates (the capacity charge) would have increased dramatically. 
At the public hearings held on SB 202, Roland $H$. Diefenderfer, DP\&L's Marketing Services Manager, estimated that the "legislation would increase DP\&L's annual revenues by almost $\$ 70$ million." 31 According to a newspaper article, several spokesmen fram the business community also testified at those hearings that their monthly electric bills would increase substantially, in one case from about $\$ 500,000$ to more than $\$ 1.6$ million or more than 3008 .

\section{Efficiency}

In testimony before the General Assembly concerning marginal cost pricing and lifeline, a DP\&L spokesman made the following points:

1. The assumption that the small user subsidizes the large user is based upon the fact that the small user pays more per kilowatt-hour of energy than does the large user. That fact is true; but it overlooks the equally important fact that it costs less per kilowatt-hour to serve a large user than to serve a small user.

2. Delmarva's average industrial customer used the same amount of electricity in 1977 as 434 average residential customers. Obviously, the costs of serving one large industrial customer. with the same amount of electricity over one line, through one transformer and one meter are substantially lower than the cost of serving 434 residential customers over 8 miles of distribution line and through more than a hundred transformers and 434 meters. Such cost differences are reflected in electric rates.

\section{Conservation}

According to the Vice-President for Corporate Planning and Regulatory Practices of DP\&L "Lifeline rates would result in reductions in the electric bill of virtually all residential customers. The lowering of these bills would

31 Wilmington News-Journal, June 3, 1977. 
tend to stimulate energy use rather than encourage conservation."

Actual studies assessing the elasticity of consumption relative to price are not available. Had this discount rate actually gone into effect, it would have been interesting to determine if a discount of this magnitude would have encouraged increased consumption within the residential class and/or had any effects on the commercial and industrial classes.

\section{Equity}

As noted, this inverted rate program was proposed for the purpose of providing a price break to small residential users. In actuality, all residential users would have benefited, to one degree or another, by the inverted residential rate and all commercial and industrial customers would appear to have been penalized by the program.

The assistance provided to residential customers would have represented a substantial discount. ${ }^{32}$ If the average electric bill of $\$ 42.00$ for $700 \mathrm{kwh}$ monthly usage were reduced to $\$ 24,33$ the annual savings to that customer would be $\$ 216$. For low-income households, the proposed lifeline would therefore provide approximately the same level of assistance as do the weatherization and heating assistance programs which have been described earlier.

According to opponents of this bill, it "tries to

\section{$3237 \%$ to $64 \%$ for usage between 200 and $800 \mathrm{kwh} /$} month; a residential discount of $9.7 \%$ would be realized at the $1500 \mathrm{kwh} /$ month level.

${ }^{33}$ As would have happened under the proposed program. 
do too much." The relatively large discount to the target group of small users and the equally large increases to the commercial and industrial (subsidizing) classes point to a program that may have created more inequities than it attempted to solve. 


\section{ILLINOIS HOUSE BILL 83}

\section{Program Summary}

Illinois House Bill 83 would have required utility companies to provide a reduced rate for a minimum of 500 kwh per month for all residential customers. Residential customers using electric space heating wore to be given a reduced rate for a minimum of $1200 \mathrm{kwh}$ per month during the heating season. ${ }^{1}$ Revenue recovery was to be from all classes of customers, "in a just and reasonable manner," excluding:

1. Sales for resale;

2. Sales to governmental entities and their institutions; and,

3. Sales to nonprofit organizations.

The actual rate per kwh was to be determined by a complex formula based on 1976 rates and sales ${ }^{2}$ and would

\footnotetext{
$1_{\text {November } 1 \text { through May } 31 .}$

$\frac{2 \text { total } 176 \text { revenue }}{\text { total } 176 \mathrm{kwh} \mathrm{sales}}+1 / 2 \frac{\text { (1st } 500 \mathrm{kwh} \cdot 76 \text { revenue }}{500}$

- total'
} 
have produced a flat rate. In addition, the utility companies were prohibited from including minimum charges, service charges or fuel adjustment charges.

Rates could be increased only when the average rate per kwh was 258 more than the lifeline rate including the proposed increase. 
Issue Development and

the Governmental Process

House Bill 83 was the Illinois Legislature's most serious lifeline attempt. It evoked weeks of spirited debate and its impact is still being felt in subsequent proposals.

The final version of the bill was nearly identical to the original version of companion House Bill 311, introduced approximately two weeks later. HB 311, which was never debated, was written by Representative Levin, an attorney who had previously represented consumer groups in rate case hearings before the Illinois Commerce Commission. House Bill 83 was drafted by the Illinois Public Action Council (IPAC) and introduced by Representative Masovictz.

While the original version of HB 83 called for a lifeline allowance of $240 \mathrm{kwh}$ and 20 therms of gas, the final version proposed a $500 \mathrm{kwh}$ allowance, a 1,200 kwh allowance for customers with electric space heating, and no provisions for gas. The bill was amended several times before being placed in a subcommittee of the House Public Utilities Committee, where it passed, after extensive 
debate, with a:11-7-0 vote. After the third reading on the House floor, Hoúse Bili: 83 was defeated 58-99-12.

\section{Rationale}

The reasons for $\mathrm{HB} 83^{\prime} \mathrm{s}$ initiation were similar to those of other lifeline,proposals: rising energy costs had caused residential' customers, particularly low-income consumers, to spend more and"more of their incomes on utility bills; the residential class had not contributed to growth in demand for electricity; therefore, it should not have to bear the burden of increasing costs.

According to an analysis by the Ilinois Legislative Services, the average electricity cost per kwh for residential consumers rose 30 to 608 more than the costs to industrial customers between 1971 and 1975. Since residential electricity demand is decreasing, it has been other classes of customers that have caused the need for new generating plants.

Besides the growth in demand argument, several other items were introduced as evidence of need for HB 83 in legislative hearings.. They were presented by warren Friedman on behalf of the Public Action Council and Citizens United for Responsible Energy.

-- A targeted rate for public assistance recipients and senior citizens (one suggestion put forth by the subcommittee on: Public Utilities) will raise the rates of the average residential user;

-- A non-targeted rate avoids the problem of discrimination among residential consumers;

- A non-targeted rate is simple to administer. Identifying and verifying eligibility for a sub-class of customers creates another bureaucracy; 
-- Real wages had declined in Illinois by nearly two percent in 1973 as utility costs soared;

-- New generating plants add to the cost of electricity; growth is uneconomical, therefore a rate which encourages conservation should be implemented;

-- Industry needs "the right economic signals" just as residents do--higher utility rates will provide these signals;

-- The ICC is quoted in a 1971 rate case (\#56427), "cost of service studies may be used to support or negate almost any proposed rate structure or design."

The rationale for setting the $500 \mathrm{kwh}$ figure, according to analysts, was the Edison Electric Institute's 1969 minimal and essential needs estimate for appliance consumption for a family of four. ${ }^{3}$ It was also believed to have been consistent with lifeline levels established in other states.

\section{Actors}

Positions of the most active participants in the lifeline controversy were typical of those taken by similar groups in other states. Major participants in committee hearings on HB 83 included IPAC, several manufacturing firms, labor, and the Illinois Commerce Commission. The ICC remained neutral throughout although it has opposed lifeline in rate cases in the past.

Testifying or pledging support of HB 83 were:

Illinois Public Action Council

Labor Coalition on Public Utilities

State Board of League of Women Voters

Several Chapters of the NAACP

United Auto Workers

Illinois State Employees Association

Operation PUSH

${ }^{3}$ Bill Analysis of HB 2027. Gary McCants, Legislative Analyst, Springfield, Illinois, April 24, 1979. 
Testifying against $\mathrm{HB}$ 83:

Black Hawk College

Illinois Manufacturers Association

Iowa-Illinois Gas and Electric

Commonwealth Edison

Central Illinois Public Service Co.

Lawyer Milton Mallin representing several firms such as Sherwin Williams, Bell and Howell,

Abbott Laboratories, and United States Steel

Defeat of Lifeline and subsequent Attempts

According to some sources, the defeat of $\mathrm{HB} 83$ can be attributed to a letter sent by Central Illinois Public Service Corporation to large residential electric users shortly before the House vote. Some 25,000 letters informed customers of the increase in rates that would occur as a result of the bill's passage. According to legislative analyst Gary McCants, the campaign was successful. Many legislators heard from their constituents. Strong lobbying by the utilities and manufacturing firms and a Chicago Tribune editorial also helped to defeat the bill.

The Illinois Manufacturer's Association, countering the claim that larqe industrial and commercial customers had contributed most to growth in electricity demand, cited the ICC in a 1975 Commonwealth Edison rate case:

The evidence of this case shows that the rate of growth in demand at the time of the system peak for small residential users was $9.4 \%$ vs. $8.7 \%$ for large residential users for the period 1972 to 1973. According to a cost-of-service study information submitted by Commonwealth Edison in this same case for the same 1972-1973 period, small and medium industrial users increased peak demand by 68 and large industrial users by $2 \%$. Thus lifeline rates, according to this information, would be stimulating, through lower prices, consumption by the users most responsible for creating peak demand: residential. 
Subsequent Attempts

There have been several subsequent attempts to pass lifeline bills in the Illinois House. All of these bills are still pending and will die if not passed in 1980 .

-- HB 2027, introduced in April, 1979, by Representative Brown, requires the ICC to establish $500 \mathrm{kwh}$ per month as a lifeline amount of electrical power. It provides a formula (similar to HB 83) for fixing rates applicable to the lifeline amount. Rates will also apply to the first $1,200 \mathrm{kwh}$ used by electric space heating customers during the winter billing period.

-- HB 2609, introduced by Representative Leckowicz, prohibits increases in rates or charges for electricity which exceed the rate of inflation, and requires the ICC to determine the quantity of electricity necessary to supply basic energy needs of a household. It provides for rates, called zero inflation rates, to be charged for such quantity.

-- HB 275., sponsored by Representative Schroeder, allows ICC to establish a special utility rate for persons entitled to claim any grant under the Illinois Senior Citizens and Disabled Fersons Property Tax Relief Act, if the special rate is a reduction of not more than 208 of regular residential rates.

-- HB 547 provides special utility bill relief grants to persons eligible for other grants under the Senior Citizens and Disabled Persons Property Tax Relief Act. 


\section{Impact}

The intended beneflctaries of: Illinois IB 83 werc to be all residential customers. Illinois has a population of $11,197,500$ (1975 estimates) : which displays the following characteristics: ${ }^{4}$

$$
\begin{array}{ll}
\text { Elderly - } & 10.38 \\
\text { Low-Income - } & 10.58
\end{array}
$$

It is not known what percentage of. Illinois' population lives in master-metered residences, and $\mathrm{HB} 83$ did not include provisions for extending lifeline benefits to those households.

Need Assessment

To assess the needs of residential customers in Illinois, bills were calculated using the statewide average consumption of $607 \mathrm{kwh}$ per month (provided by ELCON). These bills, for the four major electric utilities, are presented as percentages of low and moderate incomes in Table II. Table III presents bills for $500 \mathrm{kwh}$ usage, the amount specified in HB 83 .

${ }^{4} U . S$. Bureau of Census, Current Population Reports, Illustrative Projections of State Populations by Age, Race, and Sex 1975 to 2000, issued March 1979. Series P-25, \#796. 
TABLE II

TYPICAL RESIDENTIAL ELECTRIC BILLS FOR CONSUMERS OF FOUR UTILITY COMPANIES (ILLINOIS) AS PERCENT OF INCOME (AT $607 \mathrm{KWH} / \mathrm{MONTH}$ )

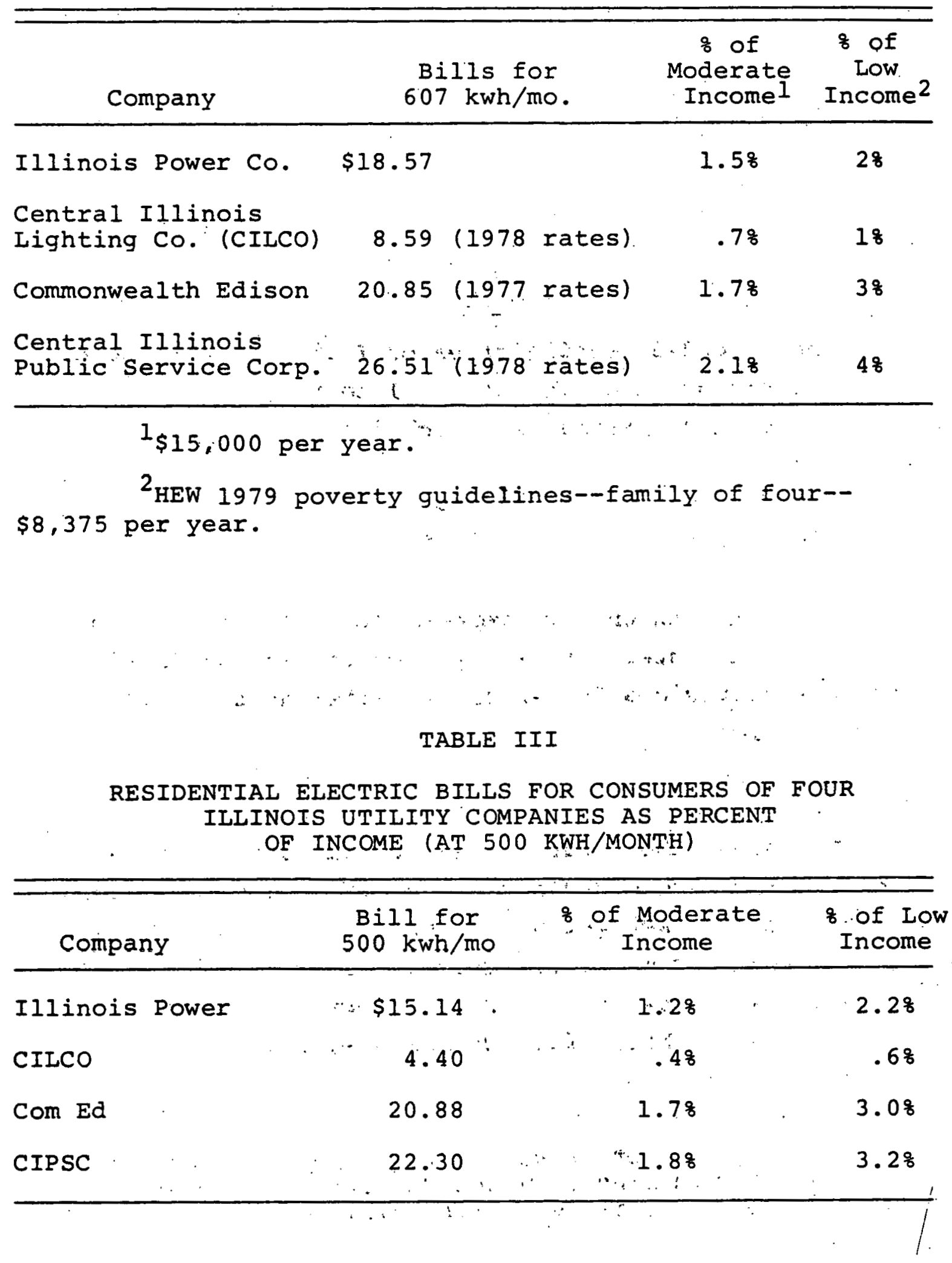


A 1979 Washington, D.C. Urban Institute report indicated that during the 1977-78 heating season, 66,566 poverty households were in "extreme need" (spent $25 \%$ or more of their incomes on heating fuel), while 198,816 poverty households were in the "moderate need" category (spent 68 of their incomes on heating fuel).5 When heating fuel costs are added to electricity costs, it seems that a substantial number of Illinois residents spend a significant amount of their incomes on energy.

In considering electricity nosts, it is worthwhile to consider service charges as a percent of the total bill. The service charge represents $6.7 \%$ of the $500 \mathrm{kwh}$ bill for Commonwealth Edison, 14.28 for Illinois Power Co., 11.78 for Central Illinois Public Service Corporation and $38.6 \%$ for CILCO. Thus, an important component of $\mathrm{HB} 83$ in addressing energy assistance needs may have been the prohibition of service charges in residential rates.

\section{Targeting Effectiveness}

Using $607 \mathrm{kwh}$ per month as the average electricity consumption of an Illinois customer, it would appear that the average residential customer would have benefitted from HB 83. This is true because the intent of this legislation 1s Inverted rates. In an inverted rate structure, benefits extend to beyond the lifeline block to a break even point, beyond which the customer pays more than he or she would have had there been no lifeline rate. Testimony presented in legislative hearings indicated that the break even point for the rates proposed under HB 83 would have occurred at $2,000 \mathrm{kwh}$.

If an implicit targeting to low-income people was intended by this legislation, then it appears that this

5 Wayne L. Hoffman, Energy Need Among' Low-Income Households: State Specific Estimates Using Several Alternative Measures (Washington, D.C.: The Urban Institute), 1979. 
targeting would also have been effective. Illinois Commerce Commission Chairman Marvin Lieberman testified that $80 \%$ of all households with incomes of $\$ 7,000$ or less have usage below $500 \mathrm{kwh}$ per month. He also testified that onehalf of all residential customers use less than $500 \mathrm{kwh}$ per month.

The legislation did not specifically call for marketing measures to ensure successful targeting.

\section{Calculation of Benefit Levels}

For the most part, the participants who testified in lifeline legislative hearings offered opinions on what the impact of HB 83 would have been. Some data was also developed on projected benefit levels to residential customers. Chairman Lieberman of the ICC presented residential bill comparisons using data from Commonwealth Edison (Table IV). These projections include elimination of the monthly service charge.

The table indicates that a significant discount (over 20\%) occurs in the $500 \mathrm{kwh}$ block. The $\$ 3.43$ reduction for that block would seem to be a significant reduction from a bill of $\$ 11.58$. Lieberman testified that, statewide, the immediate effect of $\mathrm{HB} 83$ would be to reduce the lifeline customer's bill by 228 . As a percentage of total residential income, this reduction may not have been substantial, but it would have represented a significant reduction in energy costs, particularly for those on low or fixed incomes.

\section{Revenue Recovery}

The method of recovering any revenue shortfall that might have occurred because of HB 83 was not clearly 
delineated in the bill: The legislation simply stated that it should be recovered in a just and reasonable manner. 6 .

TABLE IV

RESIDENTIAL BILL COMPARISON*

\begin{tabular}{rccc}
\hline KWH & $\begin{array}{c}\text { At } 1 / 1 / 77 \\
\text { Rates }\end{array}$ & $\begin{array}{c}\text { With } \\
\text { Lifeline }\end{array}$ & \& Charge \\
\hline 250 & $\$ 11.58$ & $\$ 8.15$ & -29.6 \\
500 & 20.88 & 16.30 & -21.9 \\
750 & 30.21 & 27.46 & -9.1 \\
1,000 & 39.52 & 37.42 & -5.3 \\
1,500 & 58.16 & 57.34 & -1.4 \\
1,821 & 70.13 & 70.13 & 0 \\
2,000 & 76.81 & 77.26 & +.6 \\
2,500 & 95.44 & 97.18 & +1.8 \\
\hline
\end{tabular}

*Commonwealth Edison Company.

In regard to revenue recovered from the residential class, Table IV also illustrated the increase to large residential users of electricity. Users of 2,000 kwh would receive less than a 18 increase in their utility bill while users of $2,500 \mathrm{kwh}$ would receive less than a 28 increase. It is not known how these figures were derived. Presumably, Chairman Lieberman used the rate-setting method prescribed in $\mathrm{HB}$ 83, which was dividing the total revenue received by

${ }^{6}$ Revenue loss was not to be offset in rates applicable to certain tax supported and non-profit institutions. 
the company from the sale of electrical power during 1976, by the total number of kilowatt hours sold during 1976, plus one-half the difference between that amount and the present average rate for the first $500 \mathrm{kwh}$.

Total annual shortfall from the lifeline proposal. was projected, by the ICC, to be $\$ 165$ milition. The loss, if borne by all non-lifeline ratepayers, would result in a uniform rate increase of 68 .

The anticipated impact of this lifeline rate on other classes was projected by several groups offering testimony. Their projections are summarized in Tables $V$ and VI.

Estimates of revenue shortfall, as illustrated in the tables, vary significantly. It is difficult, therefore to make a statement on whether new rates instituted as a result of. HB 83 would have led to a significant distortion of existing pricing mechanisms. While a figure of $\$ 1.65$ million (estimated shortfall from lifeline) appears large, this amount, when distributed to all non-lifeline customers, may not be very substantial.

\section{Efficiency}

Marginal cost arguments were raised during lifeline debates in Illinois. Taking the anti-lifeline stand were Commonwealth Edison, the Illinois Manufacturers Association (IMA), and an attorney named Milton Mallin, who represented several large industrial customers of the Commonwealth Edison Company.

The IMA argued that, unlike residential demand, levels of industrial demand for energy are based on economic 
TABLE V

IMMEDIATE IMPACT OF HB 83 USING

1977 REVENUES AS BASE*

\author{
Revenues collected from lst $500 \mathrm{kwh}$ \\ Revenues collected with lifeline \\ Revenue loss spread to other classes \\ Impact of 108 General Rate Increase with Lifeline \\ $\$ 73.8 \mathrm{M}$ or 13.58
}

$\$ 738 \mathrm{M}$

$\$ 573 \mathrm{M}$

$\$ 165 \mathrm{M}$

Amount of increase borne by other classes

before lifeline rate is increased

$\$ 714 \mathrm{M}$

Total revenue shifted from lifeline subset

$\$ 353 \mathrm{M}$

*From Chairman Lieberman's testimony. 
TABLE VI

ESTIMATES OF ANTICIPATED EFFECTS OF LIFELINE BY INTERVENORS

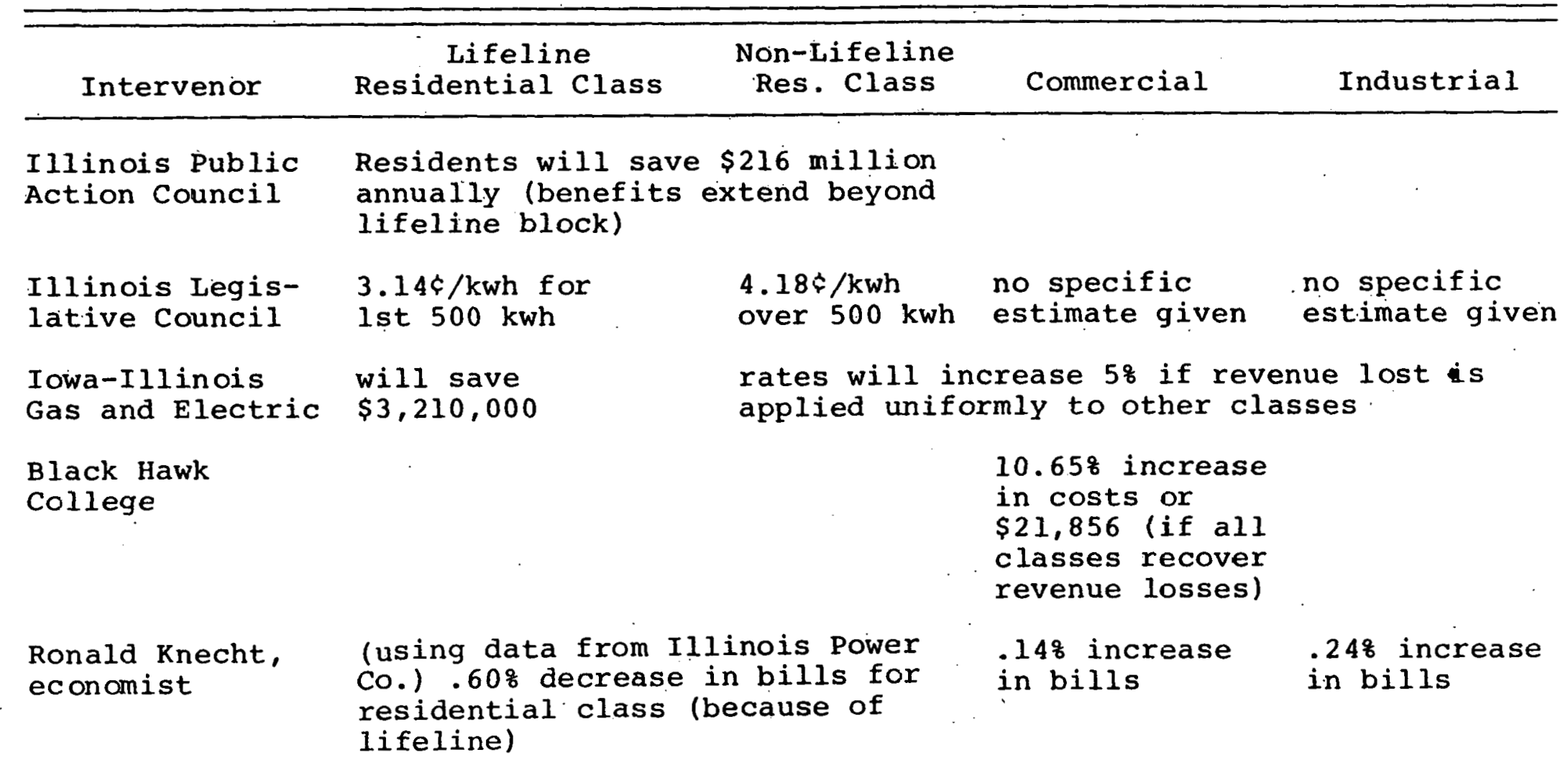

Commonwealth

Edison

Costs to all non-1ifeline classes will be $\$ 145 \mathrm{M}$ 
conditions, not weather conditions. Also, since electricity is already priced in a way that penalizes peak usage, industrial demand tends to be flattened throughout the year. Because of the absence of residential peak load pricing, IMA claimed that the residential class had caused needs for new capital investment. Thus, using marginal cost pricing principles, the residential class and not the industrial class should have had increases.

Mallin argued that large industrial customers could exercise several options if the rate increases to them as a result of lifeline became too large. These options included switching to alternate forms of energy, shifting production to other locations, shutting down high cost plants, or generating their own electricity. Generation of electricity by industrial plants, Mallin said, would reduce the utility's revenues and its load factor. In order to survive, the utility would have to increase rates to all customers.

Taking the pro-lifeline stand was economist Ronald Knecht on behalf of the Illinois Public Action Council. By using studies of demand elasticities, energy use, and revenue data from the Illinois Power Co., Knecht projected the impact of $\mathrm{HB} 83$ on company demand.

Knecht's conclusions were that lifeline would lead to an $8 \%$ reduction of the total electrical output of the utility; energy conservation would lead to lower bills for everyone; and the need to build new plants would diminish.

Figure 3 presents Knecht's findings. A summary of his methodology is given in the appendix to this case study. 
Figure 3

\section{"LIFELINE" (HB 83) EFFECT ON CUSTOMERS' EILCTRIC ENERGY USE}

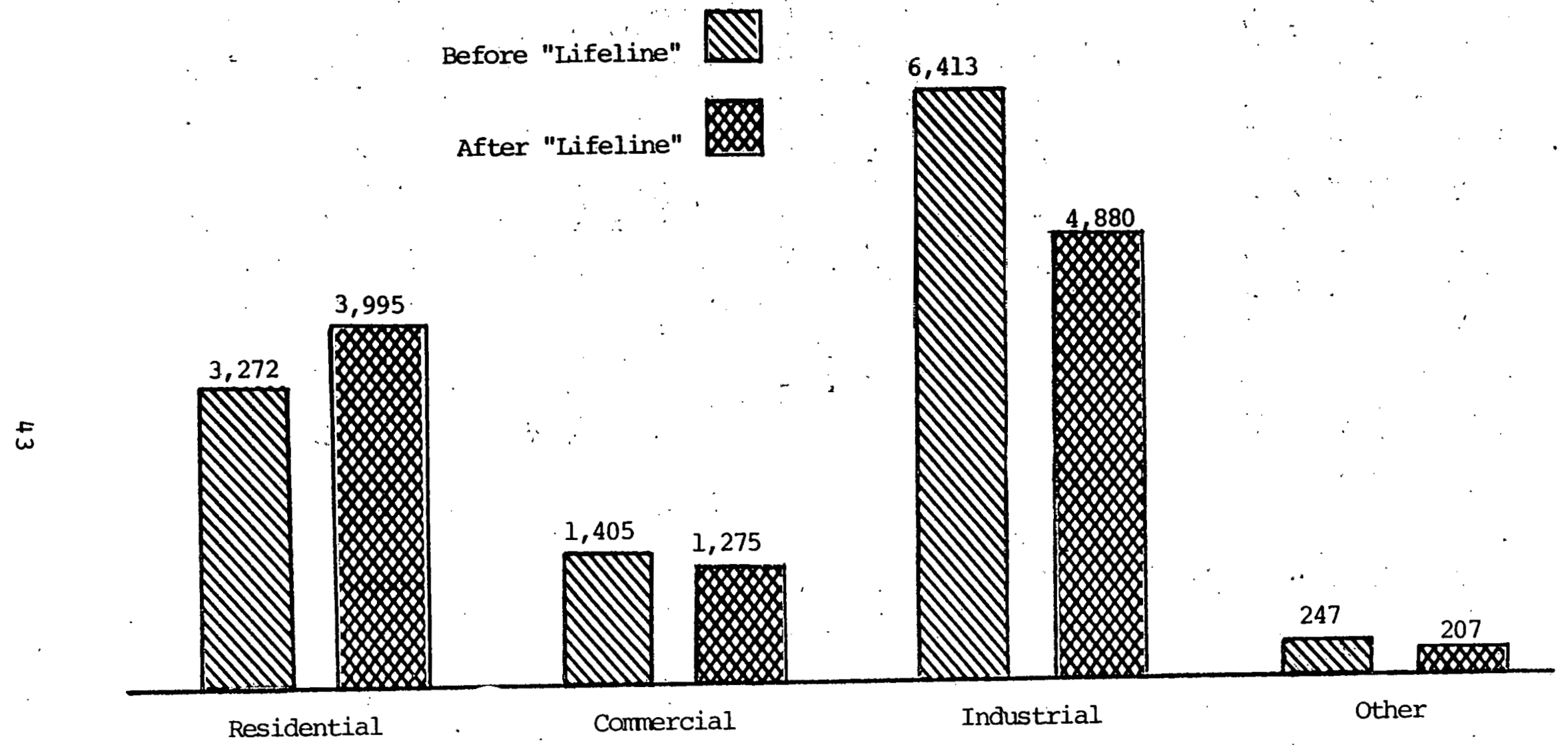

(Data specific to Illinois Power Co. customers, for HB 83 unamended, in gigawatt-hours (GWh).) 


\section{Conservation}

Specific projections of how lifeline would have affected individual consumption patterns were not available, only opinionș, and the arguments were predictable. The opponents of HB 83 said lifeline would encourage wasteful use of energy while the proponents said energy use would be decreased in the higher usage blocks and by non-residential customers.

\section{Equ1ty}

Since potential beneficiaries of HB 83 would have received savings for a usage of up to $2,000 \mathrm{kwh}, 7$ it is almost certain that the legislation would have benefitted explicit and implicit target groups.

It is also likely that the ability to pay criterion of equity would have been significantly addressed by HB 83 . Projections indicated that low-income people who use less than $500 \mathrm{kwh}$ per month ( 808 of a11 low-income people) would have received a reduction of over $20 \%$ in their utility bilis.

The recovery mechanism may have led to sharp, discontinuous rate increases for other classes if the 68 extra increase anticipated by the ICC were to be realized. However, proponents of the bill would argue that reduction in company demand would, in the long run, result in lower bills for everyone.

7.This does not take into consideration the space heating allowance. 


\section{APPENDIX}

\section{ENERGY CONSUMPTION (CONSERVATION) IMPACTS OF "LIFELINE"}

BILI (HB 83)

Results: Based on a study of Illinois, Power Company, HB 83:

1. would lead to conservation of approximately 8 percent of the total annual electrical output of the power company-a net energy conservation effect of perhaps 5 percent of the total output, considering that some of the savings in electrical energy would, be generated by changing to other (more efficient) fuels;

2. would mean lower bills for all classes of customers--since commercial, industrial and other non-residential users would cut their total consumption by an amount that would more than make up for the higher rates they would face; and

3. would diminish the need to build expensive new power plants--since the power company's load factur ha's been relatively constant for over a decade, the change in energy consumption suggests a similar change in annual system peak power demand.

\section{Methods and Data Sources:}

1. Illinois Power Company's estimates of the revenue effects of the "lifeline" bill were used.

2. Results of ten studies of demand elasticities were considered. The one which was used was recent, rated as reliable in the literature, the most comprehensive, conservative in terms of the net energy conservation impact which resulted, and offered data specific to Illinois.

3. Energy use and total revenues data for each class of customers were taken from the power company's annual report.

4. The percentage change in revenues for each class was multiplied by the price elasticity for that class to yield the change in energy consumption for the class. The sum of these changes is the net electrical conservation effect. 
5. The change in the total bill for each class was computed from the change in consumption levels and the change in rate levels.

\section{Comments:}

Choosing values for the various long-run price elasticities considered here was difficult, but reasonable values were sought and an attempt was made to be sure that all errors lead to a conservative, or understated result. It seems reasonable to suggest that similar results would be found in a study of other Illinois utilities, since their relevant characteristics resemble Illinois Power's. Finally, the results may be considered reliable for each class., but there may be great variations within each class also. 
MAINE LEGISLATIVE DOCUMENT NO. 1043

\section{Program Summary}

Maine Legislative Document No. 1043 would have provided a lifeline block of $500 \mathrm{kwh} / \mathrm{month}$ for elderly custmers. The b111 included an appropriation of $\$ 2 \mathrm{mil-}$ lion to be used for revenue recovery over a two-year period. 1

Residential customers 65 years of age or older with an adjusted gross income of $\$ 6,500$ or less were eligible for the lifeline rate. The customer was also required to have maintained a permanent residence in the state for a total of 270 days each year. The bill specified that each customer that met the age, income and residency provisions was eligible: no specific mention was made of individually or master-metered service.

The actual rate was to be set in three steps:

1. Take the applicable residential base bill amount for $500 \mathrm{kwh}$;

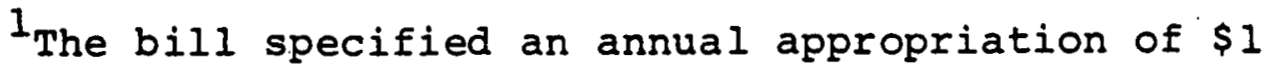
million. 
2. Add the average monthly fuel adjustment from the preceding calendar year;

3. Multiply the total by $75 \%$.

The Public Utilities Commission (PUC) was mandated to implement the remainder of the program by promulgating rules and regulations which included:

-- Method of application and information to be furnished by the applicant;

-- Method of verifying eligibility of applicants;

-- Method by which utilities would be reimbursed for revenue loss;

-- Information to be provided to the PUC to determine the amount of lost revenues attributable to lifeline rates. 


\section{Issue Development}

Major Actors and Events Prior

to Topic Legislation

Maine Demonstration Lifeline Program: The history of Iifeline activities in Maine began in the early 1970 's, resulting in legislation which established a one-year lifeline rate of $3 \mathrm{k} / \mathrm{kwh}$ for the first $500 \mathrm{kwh}$ per month for selected low-income elderly electric consumers. Carefully designed to yield representative data, the legislation empowered the Public Utilities Commission to administer and thoroughly evaluate the program upon termination. The Commission Report was a complete analysis of program history, operation, and impact. It detailed the problems encountered during the Demonstration and suggested alternatives. 2 The legislation dealt with in this case study represents some of these possible alternatives.

Electric Rate Reform Act, 1977: Immediately following the Demonstration experiment, legislation was enacted that mandated the Public Utilities Commission (PUC) "to

${ }^{2}$ For complete information, see Maine Lifeline Demonstration Program 1975-76 case study. 
relate electric rates more closely to the costs of providing electric service." The law authorized the Puc to require utilities to design temporary or experimental programs that would "encourage energy conservation, minimize the need for new electrical generating capacity, and minimize costs of electricity to consumers." Such pilot programs could affect an entire class or a portion of any class of any utility, as deemed appropriate by the Commission, providing that a utility's revenue requirements were met. Additionally, consumer interests were to be protected through the intervention of the Department of the Attorney General. The AG's office was authorized to make rate impact assessments and assist consumers in the presentation of their positions before the Commission.

Iifeline and the Legisiature: The Maine Legislature has considered a variety of lifeline rates based on the pilot Demonstration. In all cases, attempts to establish a permanent lifeline rate have failed to pass both Houses or died in committee.

According to the Office of Legislative Assistants, the Legislature meets in two sessions, a lengthy (100 days) session and a shorter (50 day) session. This shorter session is to be devoted to emergency legislation, and has historically precluded consideration of lifeline proposals. Statutes further provide that any bill that has been rejected or which dies in committee during one legislative session cannot be reintroduced, without change, for consideration during the next session.

The considerable activity described below is, in part, a reflection of the 1977 act and its predecessor, the Demonstration program. 
Legislative Document (LD) 1317 , the first of the series, was introduced in the House of Representatives on March 28, 1977 and was referred to the Joint standing Committee on Public Utilities. Echoing the basic policy statement of the Demonstration legislation which encouraged conservation and equitable rates, this $\mathrm{Act}^{3}$ would have expanded the eligibility requirements to include disabled as well as elderly residential electric consumers, regardless of income level.

The lifeline rate would be computed in a two-block profile in the following manner:

-- 0-500 kwh/month at a rate equal to 758 of the regular monthly residential rate;

-- 500-999 kwh/month at a rate more than the 0-500 kwh rate but less than regular residential rates;

-- $1000 \mathrm{kwh} /$ month or more at regular residential rates.

This bill would extend not only eligibility, ${ }^{4}$ but also the lifeline amount of electricity from the Demonstration limit of $500 \mathrm{kwh} /$ month to $999 \mathrm{kwh} / \mathrm{month}$. Fuel adjustment and other periodic charges would continue to be excluded from the lifeline rate, as per the Demonstration. However, unlike the Demonstration, customers whose usage exceeded $1000 \mathrm{kwh} /$ month were to be billed at the regular residential rate for all kwh used, even though otherwise eligible for the lifeline rate. No provisions were made for revenue losses, although a subsequent legislative attempt assumed that resultant shortfall would be passed on

\footnotetext{
${ }^{3}$ Titled the Lifeline Electrical Service Act. "To disabled and elderly" of any income level.
} 
to other utility customers. ${ }^{5}$ Although the PUC would be empowered to establish any necessary rules and provisions, eligibility certification and annual recomputation of the lifeline rate were responsibilities of each electric utility. 6

Legislative Document 1867 , introduced later ${ }^{7}$ during the same session was a revision of I.D. 1317. It differed from its predecessor in several respects.

Eligibility requirements excluded the disabled and the age of eligible participants was raised from 62 to 65 years and older. Residency requirements were brought up to those previously established by the Elderly Householders Tax and Rent Refund Act. ${ }^{8}$ Income limits were also re-established at a slightly higher level of $\$ 6,500$, as compared to the Demonstration level of $\$ 4,500$ and $\$ 5,000$.

The rate itself would still be a flat rate per kwh, computed at $75 \%$ of the regular residential rate, for each of the first $500 \mathrm{kwh} /$ month only: the second, slightly reduced block as described in the previous legislation (L.D. 1317) was deleted. Usage in excess of the lifeline amount would be billed at the regular rate. This provision would allow eligible customers to exceed $500 \mathrm{kwh} /$ month and still receive the discounted rate for the initial $500 \mathrm{kwh}$ used.

${ }^{5}$ Statement of Fact, L.D. 1867.

${ }^{6}$ Note that during the initial stages of the Demonstration, power companies strongly opposed direct utility involvement in certification of applicants.

days.

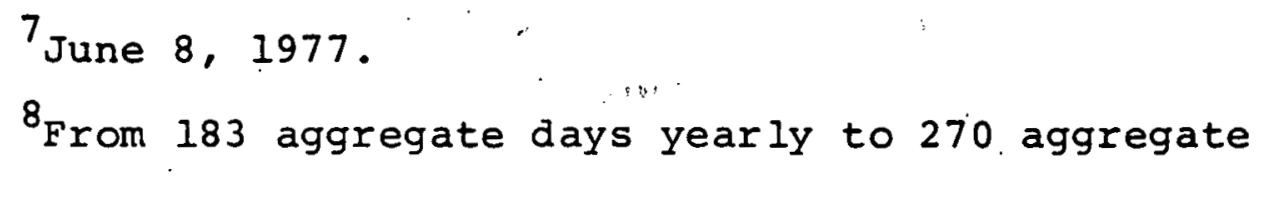


The previous legislation returned otherwise eligible customers to the regular residential rate for their entire bill. when consumption exceeded $1,000 \mathrm{kwh} / \mathrm{month}$.

Administration was to be the responsibility of the PUC, including the establishment of application and delivery methods and utility reimbursement procedures. The statute only required utilities to provide data that would enable the commission to determine the amount of lost revenues attributable to lifeline rates.

Once determined, lost revenue would be reimbursed. from the General Fund in the sums of $\$ 1,000,000$ each for fiscal years 1977-78 and 1978-79.: So, unlike its predecessor, this bill specifically provided for lost revenues. This recovery mechanism, unlike: the surcharge method of recovery used in the Demonstration, would recoup losses from a larger group of subsidizers (i.e.," taxpayers instead of ratepayers).

In the month following the presentation of this bill, three House and one Senate amendments were attached: one House amendment (dated 6/9/77). lowered the General Fund appropriation from $\$ 1,000,000$ to $\$ 750,000$; Senate amendment $6 / 13 / 77$ further clarified the funding source; House amendment $6 / 15 / 77$ reinstated the second lifeline block (per L.D. 1317), defined "applicable income" to include that of the entire household, and provided for cooperation between state agencies; House amendment $6 / 28 / 77$ instructed utilities to designate lost revenues as part of the cost of service, thereby shifting the cost burden back to the ratepayers; House amendment $7 / 8 / 77$ re-established the lifeline rate for only the first $500 \mathrm{kwh} / \mathrm{month}$. 
These predecessors and the topic lifeline legislation describe the various attempts made at solving some of the problems uncovered during the Demonstration. Problem areas occurred most often in the definition and scope of targeting, the size of the lifeline block and the funding source. ${ }^{9}$

\section{Lifeline and the Commission}

In 1978, two years after the Demonstration, the Maine PUC disallowed an elderly low-income discount rate proposed by Central Maine Power Company. This "A-ELI" rate would have discounted the first $500 \mathrm{kwh} /$ month by $20 \mathrm{z}$ for elderly SSI recipient3. The 208 reduction also applied to the increased customer charge of $\$ 4.00^{10}$ but not the fuel adjustment charge. It would have provided a maximum discount of $\$ 3.80$ to less than 18 of the population.

The Company had offered the rate "to provide rate stability to elderly low-income citizens during what hopefully will be a bridge period to meaningful . . broadbased, tax supported . . governmental relief." The Commission ruled that "it is inappropriate for Central Maine or for this Commission to make social judgments of the nature suggested by this rate, particularly in light of the legislature's rejection of a lifeline rate in 1977."11

${ }^{9}$ A simplified comparison of all lifeline legislation described in this case study appears in the following section; see chart, Legislative Activity on Central Lifeline Options, 1976-1979.

${ }^{10} \mathrm{CMP}$ was requesting an increase in the residential customer charge from $\$ 3.40$ to $\$ 4.00$. In the order from Docket No. FC 2332, the Commission increased this CMP charge to $\$ 5.70$. According to Common Cause, even the Company was surprised by the Commission's action and consumer advocates were furious.

${ }^{1 I_{A} l l}$ quotes taken from PUC Docket No. FC 2332. 
Additional Considerations

Lifeline legislation described in this study would have caused a $\$ 4.00$ monthly reduction ${ }^{12}$ in the electric bills of eligible consumers. ${ }^{13}$ At the same time, however, all CMP residential customers would have been paying a substantially increased customer charge. A Common Cause spokesman $^{14}$ advocated reducing the $\$ 5.70$ charge to $\$ 2.00$, "a more accurate reflection of customer costs." The charge was around $\$ 1.00$ several years ago; it was increased to $\$ 3.40$ in 1977 and to $\$ 5.70$ in 1974. Reducing or forgiving the charge for residential consumers could equal or surpass the proposed lifeline benefits. Common Cause proposed, however, that the energy charge be raised to encourage conservation and to recover revenue shortfall.

An alternate proposal made to the Maine Committee on Aging consisted of a 508 discount on CMP's sustomer charge, financed by an appropriation by the legislature. If the proposal were extended to the 24,000 elderly already benefitting from Maine's Elderly Householders Tax and Rent Reform Act, 15 the cost to taxpayers would amount to $\$ 816,000$ for the $\$ 34.20$ per person per year subsidy.

As evidenced by these proposals, the focus of current lifeline or utility discount programs presently appears to be shifting away from per kilowatt hour discounts and

\section{Based on CMP rates.}

${ }^{13} \mathrm{~A}$ detailed impact assessment is described in a following section of this case study.

${ }^{14}$ Testifying before the Legislature's Public Utilities Committee in April, 1979.

${ }^{15}$ An easily definable needy group. 
toward discounts on fixed charges. The consensus seems to be that, although the 1975-76 Maine Demonstration did not report significantly increased electric usage by participants, ${ }^{16}$ discounts in the energy charge may encourage wasteful consumption, and discourage conservation.

\section{Other Assistance Programs}

In addition to the federal programs, the Maine Legislature instituted an emergency energy assistance and weatherization program, P.L. $1979 \mathrm{Ch}$. 574, L.D. 1691. The bill, which extends the federal Energy Crisis Assistance Program (ECAP) income guidelines to $150 \%$ of poverty, and was passed in a special 1979 emergency session devoted to emergency measures. 17 state matching of federal ECAP funds provides up to $\$ 185$ in assistance to 708 of the approximate 126,000 eligible families.

${ }^{16}$ Refer to impact assessment section of Maine Demonstration Program case study.

${ }^{17}$ Several lifeline proposals, presented for consideration during this session, failed to clear screening and were not considered during this special session. 


\section{The Governmental Process}

1979 Lifeline Legislation

According to consumer spokesmen, after the concentrated efforts during the 1977 legislative session, there was little lifeline activity the following year. Iifeline proponents tried again in 1979 with the submission of Legislative Document 1043. Also titled the Lifeline Electrical Service Act, the bill was introduced in the first regular session of the lo9th Legislature on March 5, 1979.

In certain aspects, L.D. 1043 is nearly identical to its predecessor of 1977 (L.D. 1867). It established a flat lifeline rate for the first $500 \mathrm{kwh} / \mathrm{month}$ used by lowincome (under $\$ 6,500)$ elderly (65 or older) residents (270 aggregate days). Program administration would be the responsibility of the PUC and utilities would be reimbursed from the General Fund. As with previous bills, administrative costs were not included as itemized expenses under the biennium appropriation amount of $\$ 2,000,000$ for $1979-80$ and 1980-81.

Two House amendments were added to this bill: House amendment $4 / 30 / 79$ reduced the appropriation to $\$ 750,000$ per 
year, removed the "270 aggregate days" limitation on residency, included the consideration of "total household" income, and required the assistance of state agencies; House amendment $5 / 1 / 79$ altered the funding source from the General Fund to rate surcharges.

As described, these amendments changed the funding source from taxpayers to ratepayers and again defined income eligibility to include consideration of the resources of the entire household. The possibility of legal and/or constitutional problems wasforeseen by some legislators in the 270-day residency requirement; therefore, this section of the bill was amended to read "an individual customer... who is a Maine resident." Since the purpose of the bill was to provide Maine's elderly citizens with less costly electricity, a nine-month residency requirement was considered to be somewhat excessive.

The activity in the legislature concerning the bill and its amendments continued with the assignment to a joint House-Senate committee to study the bill. Although favored by only a minority of the 13 committeemen, the bill was accepted on the minority opinion by the House: The Senate, however, accepted the Joint Committee's majority opinion, and a stalemate ensued. The House then sought a joint com- . mittee compromise but the Senate would not agree, and consequently the bill died.

As is apparent from the above descriptions of amendments and attempted compromises, lifeline legislation was an active and volatile issue in the Maine legislature. Solutions to the problems encountered in the Demonstration program were actively sought. The following figure shows the back-and-forth tracking of amendments considered by the 
Fiqure 4

LEGISLATIVE ACTIVITY ON CENTRAL LIFELINE OPTIONS, 1976-1979

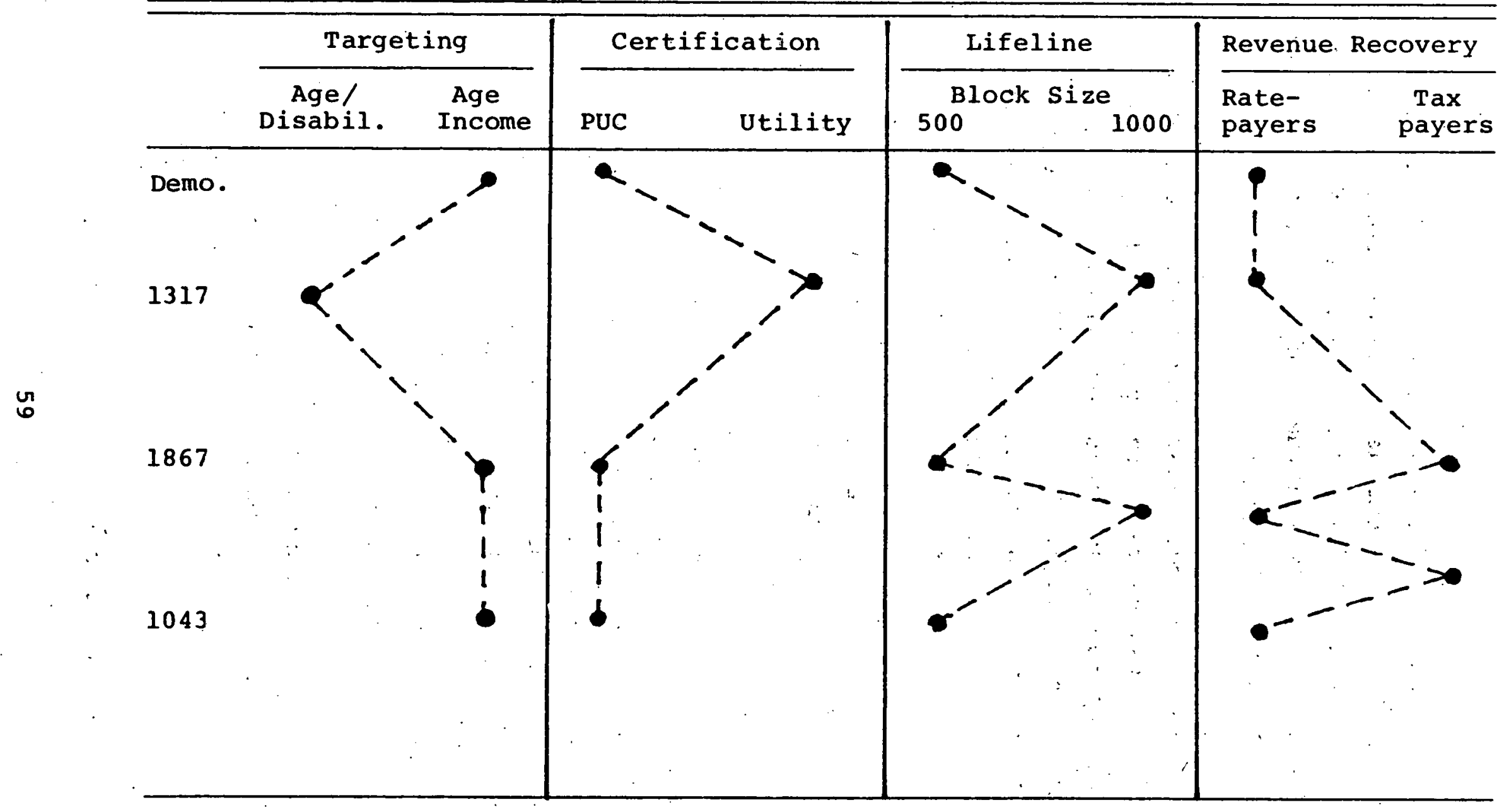


legislature. It illustrates the series of choices made by legislators in their attempt to find the most successful lifeline policy, and is followed by a brief explanation of pro and con arguments concerning these central lifeline components.

Targeting, expanded to include all elderly, was administratively more simple to verify, but offered a discount to those who may not need it. It was thought that age-only eligibility might allow the utilities to administer the program themselves, but the utilities objected, as they had during the Demonstration, to becoming involved in applicant certification.

The lifeline block of electricity was to be offered at a $25 \%$ discount below regular residential rates. This discount included the fuel cost adjustment but did not specify the inclusion of a service charge discount. This percentage-discount method ${ }^{18}$ was the only consistent component all three lifeline proposals that was not used in the Demonstration. Taken from the California Lifeline program, 19 the percentage discount method was considered to be more equitable to subsidizers due to the vast differences in electricity pricing between rural and urban utility compan-. ies.

Usage at this discount price was raised from 500 $\mathrm{kwh} /$ month to a more generous $1,000 \mathrm{kwh} / \mathrm{month}$, but this "generosity" was thought to encourage possible wasteful

${ }^{18}$ As opposed to the flat-cost-per kwh method used in the 1975-76 Demonstration.

${ }^{19}$ Also described in this report. 
consumption. Shortfall was assigned to non-lifeline residential ratepayers, to the broader based support of all taxpayers, and back to ratepayers. Persuasive arguments placed "social policy" costs as a responsibility of the whole of society and not merely of the rate paying segment of that society. Despite the popularity of this mode of thinking, excessive competition for general funds caused the defeat of lifeline appropriations.

It must be noted that the final form of the lifeline legislation, L.D. 1043, was remarkably similar in targeting, certification, block size and shortfall recovery, to the original lifeline law that enacted the 1975-76 Demonstration. Lifeline in Maine appears to have come full circle. 
The intended beneficiaries of proposed lifeline L.D. 1043 were low-income elderly ${ }^{20}$ electric consumers in Maine. This group represents approximately $18 \%$ of the total elderly population of 133,000, or approximately 24,000 persons. ${ }^{21}$ An estimated $12 \%$ of the total population of 1.5 million Maine residents were classified as low-income in 1975. Aid to Families with Dependent Children (AFDC) enrollment in 1979 was 20,000 .

The population of Maine is about evenly divided between urban and rural residents. Although information is not available as to the percentage of low-income persons who live in master-metered housing units, there were 3,318 elderly low-income households occupying public (mastermetered) housing units in 1975. None of the lifeline legislation discussed in this case study made provisions that

${ }^{20}$ Age 65 and older with household incomes of under $\$ 6,500$ annually.

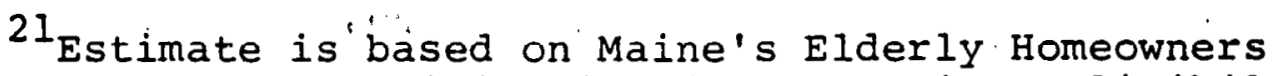
Tax and Rent Refund participation for 1979 since eligibility requirements are quite similar. 
would allow master-metered customers to benefit from lifeIine rates; ${ }^{22}$ therefore, the eligible population would be reduced by at least 3,318 .

\section{Need Assessment}

According to Department of Energy (1978) figures, while the median incame household spends approximately $5 \%$ of its income on home energy costs, many low-income families are spending over 208 of their annual budget on heat and electricity. In the coldest areas of the country, including most of Maine, poor households spend up to 358 of their incomes on energy. 23 .

Energy problems for the state of Maine are exacerbated by the major reliance on imported fuel oil for home heating. This fossil fuel has risen dramatically in price and average home heating bills were estimated at $\$ 1,100$ in 1979.24 . The target population that heats with oil spends 16.98 of an annual $\$ 6,500$ income for their home heating needs.

While average residential electricity consumption is listed at $544 \mathrm{kwh}$ per month, 25 the final report on the 197576 Maine Demonstration Program concluded that the majority of low-income elderly participants used well under $500 \mathrm{kwh} /$ month. Based on the rates of Central Maine Power Company, 26

22 see also Maine Demonstration Program case study concerning the master-metered problem.

231979-1980 Fuel Oil Availability, Affordability and Accessability. Pine. Tree Legal Assistance, Inc., Augusta, Maine, Spring 1979.

24 Final Report of the New England Energy Congress. New England Congressional Caucus and Tufts University, Somerville, MA, May 1979.

\section{${ }^{25}$ Source: State Electricity Profiles. Electricity} Consumers Resource Council, 1977 figures.

${ }^{26}$ The largest electric ut1lity with a service territory covering $70 z$ of the state's population. 
a residential customer who used $500 \mathrm{kwh} /$ month would receive an electric bill of $\$ 16.83$ (1979 rates); approximately 308 of this bill would be the service charge. Their electric bill, therefore, represents 38 of their total monthly income.

It may be concluded, then; that the consumption patterns of the target group translate into as much as $\$ 1,302$ for fuel oill and electricity annually which represents $20 \%$ of the maximum eligible income of $\$ 6,500$. Increased usage over the lifeline block; electric space heaters to augment expensive oil heating for example, would not be priced at the discount rate and the targeted customer would not. accrue any lifeline benefits from such increased usage.

\section{Targeting Effectiveness}

Application procedures were to be the responsibility of the PUC and were not specifically addressed in the legislation. Based on the results of the 1975 Demonstration program, it may be hypothesized that, with such similar eligibility criteria and administration, the participation rate may also be similar. Overall, $50 \%$ of those eligible for the Demonstration discount actually received it; this percentage, according to the Demonstration Report, was satisfactory to the Commission. If the Commission chose to link lifeline certification and marketing to the already successful Elderly Homeowners Tax and Rent Relief program, the participation rate may have been improved.

Administrative problems such as effective marketing, certification methodology and program acceptance may also have been quite similar to those that were encountered during the Demonstration. This Commission, having had considerable administrative experience in the implementation of an elderly low-income lifeline program, should be in a 
position to insure at least adequate targeting effectiveness.

Calculation of Benefit Levels

Based on CMP's 1979 rates, a residential monthly electric bill is approximately $\$ 16.83$ for usage of $500 \mathrm{kwh}$. The 25\% lifeline discount on this bill amounts to a savings of $\$ 2.78$, computed as follows:

$$
\begin{aligned}
& \$ 16.83 \text { (base rate) } \times .75+\$ 5.70 \text { (service charge) } \\
& =\$ 14.05
\end{aligned}
$$

No discount was provided for usage which exceeded $500 \mathrm{kwh} /$ month, nor was the discount applied to the service charge or the Fuel for Generation Charge. Participants therefore would be saving less than 18 of the maximum allowable monthly income of $\$ 542$.

The following table illustrates average residential bills and the savings which would have accrued to potential participants. Rates are based on CMP residential rate. sheet $A$, effective after August 22, 1979.

Note that the maximum savings of $\$ 2.78^{\circ}$ does not even equal the CMP service charge of $\$ 5.70$. For this reason, as previously described, alternative lifeline plans were proposed which focus a greater percentage discount on the service charge and do not discount the energy charge at all.

\section{Revenue Recovery}

The revenue shortfall that would have resulted from this legislation was to be recovered from a General Fund appropriation of $\$ 1$ million per, year, for two years. The legislation stated: "The General Fund appropriation is in, 
lieu of a change in the rate base of every electric utility in Maine to pass the costs on to other utility users." 27 Therefore, all taxpayers including taxpayers in the target group would subsidize the lifeline program.

TABLE VII

COMPARISON OF LIEELINE AND ACTUAL RATES.

\begin{tabular}{|c|c|c|c|}
\hline \multirow[b]{2}{*}{ KWH Use } & \multicolumn{2}{|c|}{ Monthly Bill* } & \multirow{2}{*}{$\begin{array}{l}\text { Savings/ } \\
\text { Shortfall }\end{array}$} \\
\hline & Lifeline & Non-Lifeline & \\
\hline 200 & $\$ 9.04$ & $\$ 10.15$ & $\$ 1.11$ \\
\hline $\begin{array}{c}500 \\
\text { (maximum) }\end{array}$ & 1.4 .05 & 16.83 & 2.78 \\
\hline 1,000 & 27.90 & 27.90 & -- \\
\hline 1,500 & 39.10 & 39.10 & -- \\
\hline
\end{tabular}

*Does not include Fuel for Generation Charge.

The amount of the appropriation was taken from an earlier Iifeline proposal, L.D. 1867. Exactly how the original estimate was determined is unknown, but it may have been based on information provided by the Demonstration Report which projected an estimated shortfall of $\$ 800,000$ had the Demonstration been implemented statewide.

It appears as though the funding for this program was to have been generated from existing state monies and not through any overt additional tax assessment. Although this funding method did not impose any additional tax on

${ }^{27}$ Source: Legislative Document No. 1043, p. 3 . 
the population and would not have caused increased electric rates for the purpose of revenue recovery, financing was, in fact, one of the major reasons for this bill's defeat. According to the Office of Legislative Analysis "Limited financial resources and competition among bills for these monies most severely hurt the chances of L.D. 1043."

\section{Efficiency}

As a targeted subsidy paid for by taxpayers, this program exemplifies the concept that income assistance is a societal policy and not the sole responsibility of electric consumers. It is not a program therefore that relates itself to the economics of marginal cost pricing: the discount offered is not based on customer cost responsibilities. And, according to utility spokesmen, even if it had been implemented, the relatively small number of customers actually on the rate would not have significantly affected system consumption patterns nor altered. system demand.

However, while maintaining the position that alleviating the "special crisis" of older citizens is a responsibility of society, the bill did not provide funds to reimburse either the utility companies nor the commission for their administrative costs. These additional expenses might have represented a potential budgetary burden to those responsible for administering the program.

\section{Conservation}

The conclusions which were reported by the commission and which were based on information gathered under a very similar program ${ }^{28}$ may apply here as well. Concerning conservation, it was stated that the consumption patterns

${ }^{28}$ Maine Demonstration Program; rêfer to casé study. 
of participants did not significantly change from previous usage levels: only a very small minority of participants increased their consumption by $25 \%$ during the year the program was in effect.

Recognizing the general inelasticity of the lowincome elderly as a group, the Commission noted that the majority of Demonstration participants had consistently used less than $500 \mathrm{kwh} /$ month. In other words, consumption patterns of the target group did not reflect an increase due to the availability of a discount in price. It may be concluded, therefore, that the consumption of the target group appears to be inelastic with regard to price.

\section{Equity}

A lifeline program with specific targeting is usually fairly successful in limiting assistance to only those for whom the program was intended and those who need assistance. The results of the Demonstration verify this assumption. However, the moderate (50\%) participation rate of the 1975-76 program indicates that many potentially eligible people did not benefit from the discount because they had not applied for it. Even though there are strong similarities between the Demonstration and this legislation, it is not known whether the application and marketing problems which resulted in lowering the participation rate of the Demonstration program would similarly affect this proposal or if adjustments would have been made to the program based on previous experience.

Furthermore, a maximum benefit of $\$ 2.78$ may or may not represent meaningful assistance to a low-income elderly person. Compared to the state-assisted emergency energy assistance program's maximum benefits of $\$ 185.00$ per year, 
and the fact that the service charge for the largest power company, CMP, was recently increased by an amount greater than that of the proposed discount, it does not appear that the proposed lifeline discount would have represented a significant savings.

This proposal, apparently, would not have violated the good faith criterion of equity by causing any sharp, discontinwous rate increases. Lost revenue would have been recaptured through a General Funds appropriation and therefore would not have been a factor in the rate-making processes. The program was to have been paid for by all state taxpayers, and was viewed in the context of governmental assistance.

In conclusion, the failure of this and other lifeline legislation in Maine can be attributed to the failure of a majority of Maine legislators to agree that income redistribution is best pursued through a lifeline program. 


\section{THIS PAGE \\ WAS INTENTIONALLY \\ LEFT BLANK}


MINNESOTA HOUSE FILE 1243

\section{Program Summary}

Minnesota House File 1243 required the Public Service Commission (PSC) to "explore and design potential electrical lifeline rates for residential electrical customers" within certain parameters. Acknowledging "that the cost of service is no longer the proper standard to use for determining the rate to be charged for an essential amount of energy consumption," the bill required, in part, elimination of the service charge or conversion to a minimum usage charge that would include the first $100 \mathrm{kwh}$ of the lifeline rate. The rate was to be applicable to no less than the first $500 \mathrm{kwh}$ per month, allowing consideration for regional differences in usage, and required the retention of existing summer-winter rate differentials.

The initial rate was not to exceed "the average revenue per kilowatt-hour for either the utility as a whole or the residential class thereof," and would have applied to all residential consumers including master-metered multifamily residential consumers. Special lifeline rates were also to be established for family farms, and the small 
business class was specifically prohibited from generating a disproportionately higher rate of return than other nonresidential classes.

The legislature indicated that "all classes of customers should bear the cost" of revenue recovery with the proviso that high usage residential customers should not be unduly burdened.

Once the lifeline rates had been designed by the Commission, the utility companies would have been responsible for filing revised tariffs and administration of the program. No monitoring or evaluation of the lifeline program was required by the bill.

Under the provisions of this bill, rates could not be increased until the average revenue per kwh of nonlifeline rates had increased $25 \%$, exclusive of fuel adjustment charges.

Electric cooperatives serving less than 10,000 customers or collecting more than $90 \%$ of their gross revenues from residential customers could petition the commission to be excluded from the provisions of this bill. 


\section{The Governmental Process ${ }^{1}$}

Minnesota House File 1243 was introduced on April 6, 1977 and would have affected both electric and gas rates. As mentioned in the Program summary of this case study, the Minnesota Public Service Commission (MPSC) would have been required to explore and design lifeline rates for residential electric customers within certain parameters. The. stated intent of the bill was:

The legislature hereby finds that the cost of service is no longer the proper standard to use for determining the rate to be charged for an essential amount of energy consumption for residential, small business and family farm customers; that all classes of customers should bear the cost of providing an essential amount of energy to residential customers to insure the quality of life; that the escalation of the cost of essential energy for residential customers should be slowed; and that conservation should be encouraged.

U.S. Department of Commerce (1975) estimates show the following statistics for income vs. percentage of population in the state of Minnesota:

"For a discussion of "Issue Development" in Minnesota, see the Northern States Power Conservation Rate Break case study. 


\section{Income}

below $\$ 8,000$

$\$ 8,000-\$ 10,000$

$\$ 10,000-\$ 15,000$

$\$ 15,000-\$ 20,000$

$\$ 20,000-\$ 25,000$

over $\$ 25,000$ of Population

$19: 98$

8.08

23.28

20.18

13.48

15.28

Additionally, Census Bureau estimates for 1975 show 11.28 of Minnesota's population ae clderly, and 1980 projcctions anticipate 11.6\%. Representatives Pehler, Petrafeso, Jaros and Adams were obviously aware of the need in their state when they introduced this legislation. Actions of the Senior Citizens' Coalition have also pointed to recognition of the need and support. for some type of rate relief. ${ }^{2}$

Previous attempts at legislating a lifeline rate include senate Bill 97, which was introduced earlier in the same session and a "study bill." ${ }^{3}$ This study bill was similar in nature to generic hearings held by Utility Commissions when they investigate new rate forms and would have required a number of changes in the Public Utilities Act. Both of these previous attempts were unsuccessful and both bills died in committee at the end of the session in

2 The Senior Citizens Coalition has been active in both legislative and administrative attempts to implement lifeline rates and other forms of rate breaks.

${ }^{3}$ Omnibus Utility Reform, SF No. 7--One of the effects of the bill was to "prohibit certain discounts and rate reductions based on volume." 
March of 1978. Speaking of subsequent attempts, Senator Luther, a staunch lifeline supporter who has sponsored a lifeline bill every year since 1975, said that he sees no reason to reintroduce lifeline bills since the PSC already has the authority to establish lifeline rates. ${ }^{4}$

Recognizing this authority, the PSC had ordered implementation of a lifeline rate structure for Minnesota Pnwer and Light's residential customers in 1977, and a Conservation Rate Break for Northern State Power Company's residential customers in 1978 (see NSP case study for details).

One of the primary opponents to lifeline legislation has been the Commercial and Industrial Electric Rate Task Force. The Task Force represents, as the name suggests, commercial and industrial customers. They support, among others, the following positions:

-- Adequate revenue for utilities to insure adequate and reliable service to all customers;

-- Revenue recovery for each class of customers should be based on cost of service for that class.

They oppose:

-- Cross-subsidization between classes;

- Lifeline rates as an imperfect method for effectuating income redistribution.

Minnesota Power and Light Company opposed legislation of lifeline rates also. In a monograph entitled "An

${ }^{4}$ ELCON, State Electric Update, July, 1978, p. 8 : also see Northern States Power Co. Conservation Rate Break case study for a further discussion of MPSC's authority and purpose. 
Analysis of the Lifeline Rate Issue," ${ }^{5}$ the following points were raised:

-- Lifeline rates do not promote conservation;

-- Lifeline rates will not benefit all low-income families [emphasis added];

-- Minimum necessary amounts of electricity are not quantifiable;

-- Lifeline rates require that the lifeline amount of electricity be sold below the cost of producing and. delivering the energy.

The Minnesota Farm Bureau has also generally opposed lifeline rates due to their negative economic impact on farmers and other large users. Their testimony has relied heavily on a California Farm Bureau study. ${ }^{6}$ Among other things the California Farm Bureau objected to the PUC's: protection of residential customers at the expense of other classes.

On the other side of the issue, the PSC supported the bill.: In addition to lending support to the PSC's generally positive feelings towards lifeline, H.F. 1243 would have required the commission to explore, design and implement lifeline rates. At the very least, enactment of this bill would have relieved some of the pressure on the PSC by removing the merits of lifeline as an issue from discussion in rate cases.

Approximately eleven months after its introduction H.F. 1243 was passed by the House and was referred to the Senate. The bill died less than two weeks later when the legislative session adjourned.

${ }^{5}$ By Randall J. Falkenberg, Minnesota Power \& Light, Rate Engineer, December 15, 1977 .

${ }^{6}$ California Farm Bureau Federation, Statement to the Joint Committee on the State's Economy, by Glen Sullivan, February 15, 1978. 


\section{Impact}

The intended beneficiaries of the lifeline rate proposed by H.F. 1243 were residential customers who used approximately $500 \mathrm{kwh}$ per month or less. 7

In the state of Minnesota, the U.S. Census Bureau estlmated 1975 population at $3,921,400$ and 1900 projected population at 4,039,900. These numbers, however, do not reflect the number of customers who would have been eligible for the rate. The reasons for this include:

- Households (billing entities) versus actual population;

-- Approximately 200,000-residential customers are served by 120 municipal electric companies that are not subject to PSC regulation;

-- Approximately 450,000 residentiäl customers are served by 51 rural electric co-ops that could petition the PSC for exemption from regulation under H.F. 1243.

This potential target population includes $11.2 \%$

${ }^{7}$ Language in the bill indicated that the lifeline rate would apply to no less than $500 \mathrm{kwh} / \mathrm{month}$. 
elderly, based on 1975 estimates and over 53,000 poverty. families who expend 258 or more of their income on heating fuel, according to a study by the Urban Institute in Washington, D.C. ${ }^{8}$ Again, distribution of elderly and needy families between investor-owned and municipal companies or rural co-ops is not known.

The target population is essentially urban ${ }^{9}$ but contains a large number of farms which, under H.F. 1243, would have been eligible for a family farm lifeline rate. The largest concentration of population is in the Minneapolis/St. Paul area.

It is interesting to note that, unlike other legislation, H.F. 1243 called for the establishment of a new service class called "master-metered multifamily residential." This class would have received the same degree of protection as single metered residential customers. No mention was made, however, of master-metered customers whose utilities might be included in rent payments.

Although specific information relative to consumption patterns was not presented during the hearings for this bill from the investor-owned utilities affected, the following table is a selected comparison of typical energy bills from Minnesota Power and Light and Northern States Power. 10

8wayne L. Hoffman, Energy Need Among Low-Income Households: State Specific Estimates Using Several Alternative Measures (Washington, D.C.: The Urban Institute), 1979.

${ }^{9} 66.48,1970$

${ }^{10}$ Typical Electric Bills, Residential, January 1, 1978, Federal Power Commission. These figures are representative only and actual figures vary slightly in different areas. 
TABLE VIII

TYPICAL ENERGY BILLS FROM MINNESOTA POWER AND LIGHT AND NORTHERN STATES POWER

\begin{tabular}{lrrrrr}
\hline & $100 \mathrm{KWH}$ & $250 \mathrm{KWH}$ & $500 \mathrm{KWH}$ & $750 \mathrm{KWH}$ & $1,000 \mathrm{KWH}$ \\
\hline MP\&L & $\$ 7.15$ & $\$ 13.38$ & $\$ 23.75$ & $\$ 33.49$ & $\$ 40.64$ \\
NSP & 6.85 & 13.38 & 24.26 & 35.14 & 46.02 \\
\hline
\end{tabular}

Since only a rate formula, and not a specific rate, was indicated by the bill, possible savings under the proposed rate are unknown.

Revenue recovery was not specifically addressed in the bill either, but the following provisions were included:

-- The Commission shall not unduly burden high usage residential customers;

-- No small business class that is shown to be generating a disproportionately higher rate of return, compared to other nonresidential classes, shall be required to absorb a portion of any interclass burden created by implementation of lifeline rates;

-- The Commission shall not implement lifeline rates which have the effect of increasing utility costs for agricultural family farms.

No specific information appears to have been presented during testimony relative to efficiency or conservation with the exception of the general claim that lifeline rates do not promote conservation. In partial refute of this claim, information is included in Northern states Power Company's Conservation Rate Break case study, in Volume 2.

With the exception of stating where revenue was not to be recovered, equity per se, was not addressed by the legislature in this bill. As in almost every case however, 
the question, was raised by commercial and industrial customers who objected to subsidizing other classes of customers. 
NEW YORK ASSEMBLY BİLL $12214^{1}$

\section{Program Summary}

New York Assembly Bill 12214 would have established a two-block rate break/conservation incentive for all residential customers of investor-owned utilities. The segments of the rate were called the "savings incentive plan" and the "basic usage level."

The savings incentive plan included $400 \mathrm{kwh} / \mathrm{month}$ or the average residential usage for each utility company, whichever was less. The average was to be recomputed annually.

The basic usage level included $200 \mathrm{kwh} / \mathrm{month}$ or one-half of the average residential usage for each company, whichever was less'.

These rates would have been applicable to all residential customers with individually metered service.

. 1Two bills from New York have been studied. for this report. Issue Development and the Governmental Process have been combined, but separate Program Summaries and Impact statements are provided. 
The rate-making formula and the method of revenue recovery were based on a series of interdependent provisions.

1. A.B. 12214 contained an appropriation in the amount of $\$ 35$ million to be allocated to the participating utility companies for the purpose of revenue recovery.

2. Each electric company's share of the appropriation was to be based on gross revenues from sales up to the basic usage level (200 kwh or less). Each company's share was to bo determined by the FSC based on the ratio between one company's revenues from these sales as compared to statewide gross revenues of all participating companies' revenues from these sales.

3. The rates were to be set so as to pass on to residential customers, savings equal to the portion of the appropriation received by the utility company.

4. Rates for the basic usage level (below $200 \mathrm{kwh}$ ) were to be set below those of the second half of the incentive plan (201-400 kwh, maximum).

5. Rates were to be set so that no residential customer would realize an increase or decrease in rates for usage above the $400 \mathrm{kwh}$ level.

Annually, the appropriation was to be evaluated, and each utility's share of the appropriation was to be rec computed.

In addition, the Commission was required to "implement a comprehensive information and education program designed to ensure that residential electric customers are aware of, understand and use the savings incentive rate .. "

Any revenue loss that was not covered by a utility's share of the appropriation was subject to a gross receipts tax credit. 
NEW YORK SENATE BIIL 7.013-A

\section{Program Summary}

New York Senate Bill 7013-A would have established a lifeline block of $200 \mathrm{kwh} / \mathrm{month}$, or a portion thereof, for elderly customers. The majority of lost revenue was to be recovered by the utility through a gross receipts tax credit. The utility was permitted to recover $95 \%$ of their lost revenue in this manner. The remaining 5 was not specifically addressed in the bill:

The lifeline rate would have been available under the following conditions:

-- A residential customer must be at least 62 years of age;

-- Resident may not share his residence with more than one person who is less than 62 years old;

-- Electric service must be to a single-family dwelling or an individually metered apartment.

Neither application nor eligibility verification procedures were addressed in the bill. 
The Public Service Commission (PSC) was to determine the rate. The rate set was not to exceed the average residential rate, including the fuel adjustment charge, in effect for each utility company on January 1, 1978. The Commission was also prohibited from allowing increases in the lifeline rate until the system-wide rate for a utility company had increased by $258^{2}$ over the January 1, 1978

level. If an increase was allowed, it could not exceed the proportional increases authorized for other classes taken together.

No minimum charges, fuel adjustment charges or other periodic charges could be applied to usage within the - lifeline block.

\footnotetext{
${ }^{2}$ Including fuel adjustment charges.
} 


\section{Issue Development}

Lifeline bills have been introduced in the New York legislature since around 1975. Primarily responsible for their initiation were consumer groups, particularly the Public Utility Law Project (PULP) and the New York Public Interest Research Group (NY-PIRG).

In their support of lifeline, these groups have continually stressed the need to provide some relief from rising utility costs to the poor and elderly. The following items were presented as part of a need assessment for passage of a lifeline bill:

-- The cost of electricity has soared at a rate of three to five times the cost of living (1978 testimony) :

- New York has the highest electricity rates in the country, yet small-use residential customers, largely the poor and the elderly, pay much higher rates than large-use residential customers and business;

-- Under the two bills being studied, commercial and industrial rates would not be increased and there would be no impact on utility revenues; 
-- For many low and moderate income families, utility bills now represent the third highest cost behind shelter and food;

- Electric service is used by residential consumers for lighting, food preparation and, in some cases, heating, and is a basic necessity of life;

- For the poor, the elderly and those on fixed incomes, electricity costs have become a hardship. Most use only the amount of electricity needed for essentials and therefore use less than average amounts of electricity;

-- Declining blocks are a disincentive to conservation;

-- Due to the continuing energy crisis, energy conservation chould be a top priority in all state energy policies, incluaing electric rate setting. Conservation by customers who use electricity for other than basic necessities should be encouraged.

Previous/Subsequent Attempts

In addition to the two bills under study, 7013-A (1978) and 12214 (1978), several pieces of lifeline legislation have been introduced in New York. Most have died in the Assembly Corporations Committee without being heard. None has passed either the Assembly or the Senate.

Assembly Bill 8757-C, June 30, 1975--This bill would have required the PSC to establish a lifeline block based on minimum essential needs of a residence having a family of four. Rates for this block would have been frozen at existing rates. Increases were to be placed on higher-use blocks and other classes of customers.

Assembly Bill 7908-A, March 29, 1977--A maximum lifeline block of $300 \mathrm{kwh}$ per month was mandated by this legislation. Rates were to be frozen for this blok. A 25\% differential between lifeline and average system rates was also mandated. 
Assembly Bill 1947-A, January 24, 1979--This would have established a lifeline block of $200 \mathrm{kwh} / \mathrm{month}$. Elderly customers were to have received rates for this block priced at no greater than average system rates. Up to $95 \%$ of the revenues lost by the utility could have been deducted from state taxes.

Assembly Bill 3392, February 20, 1979--Under this bill, low-income elderly customers would have received a $50 \%$ reduction in gas and electricity rates.

Assembly Bill 5647, March 6, 1979--AB 5647 would have established a lifeline block of $200 \mathrm{kwh}$. Reduced rates for this block were to be granted to elderly customers. Revenue loss could be regained through state tax credits.

Assembly Bill 6358-B, March 22, 1979--Rates to elderly customers, under this bill, were to be priced $10 \%$ lower than the average system rate, for no more than 500 kwh. Fifty percent of the revenue loss could be made up in the form of a tax credit.

Assembly Bill 7057, April 2, 1979--A lifeline rate for all residential customers was to be established under 7057. The lifeline block was not to exceed $300 \mathrm{kwh}$ per month and the rate was to be set at 108 below the average system rate. Any revenue loss could be recovered by a credit against any gross receipts tax.

\section{Actors}

Consumer Groups

PULP has been one of the leading proponents of lifeline in New York. It is a federally funded (National 
Legal Services and Community Services Administration) advocacy office representing the interests of low-income utility consumers. According to its fact sheet, PULP's goal "is to develop and implement a model, replicable in other states, of how low-income people can affect public and private decision-making which impact them as consumers."

Support of lifeline has also been given by NY-PIRG, legal aid services throughout the state and PULP's affiliate, an outreach organization called Consumer Advocacy in the Energy Crunch. Representatives of two of these organizations did not particularly like a lifeline rate for one group of poor customers rather than another (a rate targeted to the elderly, for example) but also said that "something was better than nothing." One contact said he would like to see the service charge on utility bills eliminated.

In their testimony, consumer groups also cited as evidence several studies which indicate there is a strong correlation between income and electricity use.

\section{Utility Companies}

All of the major utilities in inew York, including Consolidated Edison, Long Island Lighting Company, Niagara Mohawk, New York State Electric and Gas, Rochester Gas and Electric and Central Hudson, have testified against lifeline either in the legislature or before the PSC. Standard arguments against the rate form, such as it is not costjustified, have been presented.

In hearings before the Commission in 1978, the Long Island Iighting Company presented as its witness, attorney Joe D. Pace. Pace said that a lifeline rate could hurt 
poor people living in master-metered apartments and those. who have electric space or water heating, and offered data. on usage characteristics. This will be presented in the "Impact" section of this case study.

Manufacturers Associations

Although testimony from manufacturers was not readily available, a spokesperson for the New York Manufacturers Association said his organization has opposed lifeline legislation. 


\section{The Governmental Process}

The Legislature

According to Joyce A. Chupka of PULP, the legislature is divided on the issue of what form of lifeline to adopt, consequently, nothing has passed. This is added to the fact that the PSC has generally opposed lifeline and there was lobbying against the legislation by the utilities and by commercial and industrial customers.

The Republican-controlled Senate has leaned toward a lifeline rate for the elderly with a tax credit given to the utility, while the Democratic-controlled Assembly has favored inverted rates, or a lifeline rate for all residential customers. 12214-A and 7013-A never made it out of the Assembly Corporations Committee.

Public Service Commission

In 1975, the PSC began a generic rate case, part of which dealt with lifeline rates and marginal cost pricing. By March 1, 1977, it had received briefs or comments from the staff, six utilities, commercial consumers (the ChemungSteichen Energy Council, the Industrial Power Consumers Conference, Multiple Intervenors, Corning Glass Works and r. 
Thatcher Glass), residential consumer groups (Chemung Legal Services and NY-PIRG) and the Empire state Petroleum Association.

In regard to lifeline, the Commission held that the concept is relevant to a determination of just and reasonable electric rates. However, it had serious reservations about actually implementing the rate for any utility and said that "advocates of such proposals bear a heavy burden of persuasion." Proponents were required to demonstrate that:

1. Lifeline rates are not unlawfully discriminatory;

2. They can in fact achieve their purpose of providinc assistance to the needy;

3. The benefit to the needy does not result from the placing of an undue burden on other customers;

4. They can be administered simply; and,

5. They will not significantly distort price signals to induce uneconomic consumption patterns.

The PSC used these factors in considering two types of lifeline (I) lifeline proposal which intentionally charges. rates less than the assumed cost of service and (2) a costjustified lifeline proposal which utilizes marginal cost principles.

Primarily because it was not convinced that a substantial number of low-income users were not large users of electricity, the Commission rejected the first form of lifeline. Regarding the second, the Commission considered a proposal by Professor Robert Frank of Chemung County Legal Services. I Frank's proposal would have created a link between the problem of the impact of rising energy costs on the poor and the move toward designing rates based on

$1_{\text {As }}$ referenced in several legal briefs filed for Case No. 26806, dated February and March, 1977. 
marginal costs. His idea was:

-- For economic efficiency, each consumer should be charged the marginal cost of providing him with service;

-- Marginal cost is defined as including (1) replacement cost of electric plant including cost increases attributable to inflation, and (2) marginal social costs of production including production externalities (like increased air and water pollution) and alleged imperfections in factor input markets (like the failure of coal prices to reflect the cost of restoring stripmined lard);

- Marginal costs are substantially above average costs and present rates and would; therefore, produce revenues far in excess of fair return on capital;

-- The surplus revenues should be returned to consumers in a manner that will not alter the marginal cost price signals; and preferably through rebates that would favorably redistribute income.

The PSC did not fully accept Frank's proposal, particularly because it thought the inclusion of social costs and the determination of their value would be questionable. However, it did order an experiment to be implemented so that the issues surrounding marginal costs could be evaluated further.

Two experiments were ordered for three down-state utilities, Consolidated Edison; IILCO, and Orange and Rockland Utilities. Samples of 400, 200 and 150 general use residential customers were chosen for each of the respective utilities. These companies already had load studies of equal numbers of customers who could be used as a control group. Income data was to be gathered on the participants and they were to be given an education program as part of the selection process. 
Various rates, such as flat, time-of-day rates based on marginal cost, lifeline rates for on-peak and offpeak use and elimination of the customer charge, were to be designed by the companies and approved by the PSC.

The order for this experiment was issued August 30, 1978. It was estimated then that approximately two years would be needed just for initial data gathering (including. an update of marginal costs), and rate designing. The experiment, which is to last for five years, has not yet been implemented.

Three of the six Commissioners in New York concurred with the ordering of the experiments, but "with littlc enthusiasm." Not erough had been done, they said, to provide relief to those who needed it immediately. 


\section{Impact.}

The intended beneficiaries of the proposed Assembly Bill 12214 were all small-use residential customers, or potentially, all residential customers. This group appears to have the following demographic characteristics:

-- Total population was 18,076,000, according to 1975 U.S. Census Bureau estimates;

-- Approximately 11.3\% were elderly;

-- Approximately $9.4 \%$ were low-income people.

New York's population is 88.98 urban, according to 1970 Census fiqurés. For some idea of how many residents pay for electricity, in 1976, approximately 49.38 of New York's housing units were owner-occupied. ${ }^{2}$ Provisions to extend lifeline rates to renters were not included in the legislation.

Need Assessment

Two sets of data on electricity usage characteristics of the population of New York are available. The

${ }^{2}$ U.s. Bureau of the Census." County and City Date Book, 1979 (A Statistical Abstract Supplement), U.S. Government Printing Office, Washington, D.C. 20402. 
first, presented in Table IX, was part of testimony by the Public Utility Law Project (PULP) in support of a different lifeline bill (7908-A, 1977). Nevertheless, the data is relevant.

TABLE IX

PERCENTAGE OF FAMILY INCOME SPENT ON ELECTRICITY IN NEW. YORK STATE

\begin{tabular}{lcccc}
\hline & & $\begin{array}{c}\text { Avg. Monthly } \\
\text { Use of } \\
\text { Average } \\
\text { Electricity } \\
\text { (KWH) }\end{array}$ & $\begin{array}{c}\text { Avg. Annual } \\
\text { Electricity } \\
\text { Bill }\end{array}$ & $\begin{array}{c}\text { ofotal } \\
\text { Annual } \\
\text { Income }\end{array}$ \\
\hline Poor & $\$ 3,000$ & 335 & $\$ 191$ & 6.4 \\
Lower Middle & 7,000 & 396 & 230 & 3.3 \\
Upper Middle & 11,000 & 458 & 257 & 2.3 \\
Well uff & 17,000 & 568 & 326 & 1.9 \\
Well off & 29,000 & 761 & 449 & 1.5 \\
\hline
\end{tabular}

Source: Federal Power Commission and Federal Energy Commission statistics as cited in Exhibits 72, 71 of PSC Case 26806 .

The poor spend proportionately 4.3. times more of their income on electricity than the well off, yet their consumption is less than half. In New York State the lower income groups, because of their lower usage rates, pay 188 more per kilowatt hour than the well off. 3

The second set of data (Table $X$ ) was based on 1970 Census Data and used in testimony by Mr. Joe D. Pace on behalf of the Long Island Lighting Company. It contrasts

$$
3 \text { PULP. }
$$


TABLE X

CENSUS DATA RELATING TO ELECTRICITY USE IN NEW YORK STATE 1970

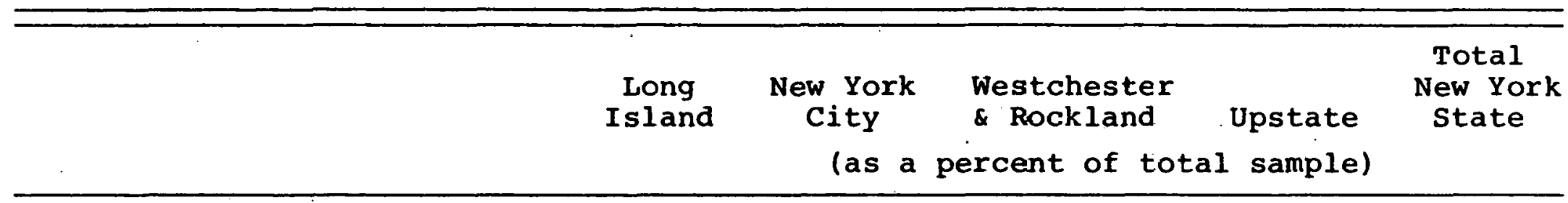

Low-Income Families

(Income less than $\$ 4,000$ )

Electric payments included in rent:

(1)

(2)

9.1

18.9

1.2

1.4

0.8

1.2

7.8

1.8
18.3

18.3

70.7

Live in single-family home

Five or more persons in

family

\section{Space hea}

cooking on ly
9.37 .1
(3)

(4)

17.5

2. 8

6.7

1. 4

3. 5

22.4

4. 6

5.7

17.1

24.2

1.7

13.3

45.8

17.0
7.3

11.0

1.2

6.5

24.8

6.7 
Table $x$ (Cont'd.)

\begin{tabular}{|c|c|c|c|c|c|}
\hline . & $\begin{array}{l}\text { Long } \\
\text { Island }\end{array}$ & $\begin{array}{c}\text { New York } \\
\text { City } \\
\text { (as a }\end{array}$ & $\begin{array}{l}\text { Westchester } \\
\& \text { Rockland } \\
\text { rcent of total }\end{array}$ & $\begin{array}{l}\text { Upstate } \\
\text { sample) }\end{array}$ & $\begin{array}{l}\text { Total } \\
\text { New York } \\
\text { State }\end{array}$ \\
\hline \multicolumn{6}{|l|}{$\begin{array}{l}\text { High-Income Families } \\
\text { (Income exceeding } \$ 20,000)\end{array}$} \\
\hline $\begin{array}{l}\text { Use no major electric } \\
\text { appliances } 1\end{array}$ & 44.6 & 81.1 & 67.9 & 31.3 & 59.3 \\
\hline $\begin{array}{l}\text { Live in multi-family } \\
\text { home }\end{array}$ & 4.9 & 60.9 & 14.8 & 5.5 & 29.4 \\
\hline $\begin{array}{l}\text { One or two persons } \\
\text { in family }\end{array}$ & 20.4 & 39.5 & 26.1 & 25.5 & 30.5 \\
\hline
\end{tabular}

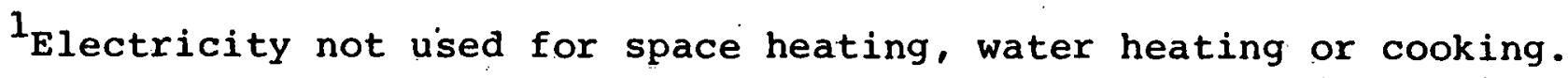


electricity consumption of low-income people with energy consumption of high income families.

It must be noted that Pace's testimony uses a very low low-income figure. Table IX would indicate that a larger percentage of income is spent by low-income families for electricity though most do not live in single-family homes (see Table $\mathrm{X}$ ). Of those who do pay for electricity, most of the electricity is used for cooking. Electricity usage for lighting was not given.

In regard to total energy costs for the New York State residents, the following items should be considered:

-- In the 1977-78 heating season, 135,447 poverty households spent more than 258 of their income on energy expenditures, 318 of all poverty households fell into this category;

-- Some 309,901 poverty households spent 68 or more of their income on energy; this constituted some 718 of all poverty households. ${ }^{\text {th }}$

Targeting Effectiveness

All of the residential population was "targeted" to receive a lifeline break under this bill. However, an implicit targeting to low-income people was intended. To give some indication of who would be helped by a lifeline rate for a block of $400 \mathrm{kwh}$, data was obtained on frequency of bills falling in certain usage categories, for welfare and non-welfare recipients served by Consolidated Edison.

Way.re I. Hoffman, Energy Needs Among Low-Income Households: State Specific Estimates Using Several Alternative Measures (Washington, D.C.: The Urban Institute), 1979. 
This data indicated that $93.9 \%$ of public assistance recipients would benefit from the $400 \mathrm{kwh}$ block (winter use). Over half would benefit from lifeline rates for just $200 \mathrm{kwh}$. Some $60 \%$ of "non-welfare" consumers also use less than $400 \mathrm{kwh}$ per month during the winter, although only $28 \%$ would benefit from lifeline rates for $200 \mathrm{kwh}$.

Thus, it would seem that the bill would be successful in reaching most of its explicit and implicit target populations. A program was to have been mandated by the legislation'to, in effect, market the rate. Bill 12214 read,

The Commission shall establish and implement a comprehensive information and education program designed to ensure that residential electric customers are aware of, understand, and use the savings incentive rates.

\section{Calculation of Benefit 'Levels}

Studies which may have projected the savings to residential customers as a result of lifeline block electric rates are not available. In order to calculate those savings, the lifeline rate.would have to be known and it is not. However, a rough calculation can be made based on the projected revenue loss of $\$ 35$ million. If that amount were distributed to the state's 2,042,588 low-income people (and assuming those people used $400 \mathrm{kwh}$ per month or less), an individual's savings per year would amount to approximately $\$ 17$, or less than $\$ 2.00$ per month. This does not appear to represent a significant portion of income.:.

\section{Revenue Recovery}

Revenue shortfall was to be recovered by the utility in the form of a credit against any gross receipts tax it may have been liable for under the state's tax law. This shortfall was projected to be $\$ 35$ million. In other words; some $\$ 35$ million was to have been allocated by the state in anticipation of the tax income loss. The adequacy of the 
allocation was to have been reviewed and reconsidered annually by the PSC, which was to then report to the Governor and the legislature.

It would seen that this form of revenue recovery would be the least damaging to nonresidential classes of customers since they would receive no increase in rates as a result of lifeline. However, the state, in funding the program, may have been forced to raise taxes so that eventually some or all of the population would have paid for the rate. One of the reasons lifeline proposals of this sort have been defeated, say some sources, is that the state simply didn't have the money or was unwilling to spend the money and possibly cut back on other services.

Thus, while a customer's overall income may have been affected by this rate because of an additional tax, it would appear that 12214 would not significantly distort the pricing mechanism for utility rates to non-lifeline classes.

\section{Efficiency}

Marginal cost was not an issue before the legislature in its consideration of lifeline. As mentioned in a previous section, it has been an issue in PSC rate cases. To reiterate briefly, the Commission believes marginal cost pricing is valid in principle and so it has instituted experimental rates based on marginal costing principles for three of the state's major utilities.

No projections on the effect of Bill 12214 on peak demand were available.

\section{Conservation}

The supplemental savings rate was designed to encourage conservation in the $400 \mathrm{kwh}$ block, but to have no 
effect on usage above that amount. 5

To provide even more of an incentive for coniservation, the first $200 \mathrm{kwh}$ were to have been charged less than the second $200 \mathrm{kwh}$. Residents were thereby encouraged to reduce their usage even further. However, specific projections on how much energy would actually have been conserved are not available.

Equity

Based on low-income usage figures, the Energy Savings Incentive Plan would have reached its intended target population. It would have addressed the ability to pay criterion of equity; however, how significantly this criterion would have been addressed is difficult to determine because a specific rate was not provided in the bill. Also, the good faith/reasonable expectation criterion of equity would not have been violated since no change in non-lifeline rates would have occurred. Consequently, it seems as if the program generated by this legislation could have been effective.

The only entity negatively affected by this plan would have been the state. Information on whether the state could afford the tax revenue loss or how that revenue loss would have been recovered is not readily available. Apparently, the state legislators. felt that New York could not afford the revenue loss.

${ }^{5}$ Rates would not be increased or decreased for usage in excess of $400 \mathrm{kwh}$. 
Impact

The intended beneficiaries of the Lifeline Block Electric Rates were residential customers over the age of 62. According to 1978 Census Bureau estimates, 11.88 of the state's population was elderly (over 65). According to a legislative analysis of the bill, approximately 600,000 electric customers were over age 62 in New York state.

Implicitly, the elderly who are poor were the intended beneficiaries of this bill. A detailed profile of the energy usage characteristics of the elderly poor was published in 1978 by Welfare Research, Inc. of Albany, New York, and called The Impacts of Rising Energy Costs on the Elderly Poor in New York State. Some 396 elderly. New York state residents, 246 who lived in New York City and 150 who lived in Albany and surrounding areas, were surveyed for this study. It provided a description of not only the financial impacts of energy costs, but of the psychological, behavioral and health impacts as well.

The income characteristics of the sample population compared to the income of elderly New York City residents is. given in Table XI. The table indicates that, at least 
TABLE XI

HOUSEHOLD INCOME ${ }^{1}$ OF SAMPLE POPULATION (BY \&)

\begin{tabular}{|c|c|c|c|c|}
\hline $\begin{array}{l}\text { Amount of Annual } \\
\text { Income }(\$)\end{array}$ & $\begin{array}{l}\text { Survey Sample } \\
\text { Combined } \\
\text { NYC and Albany }\end{array}$ & $\begin{array}{l}\text { Survey } \\
\text { NYC }\end{array}$ & $\begin{array}{l}\text { Survey } \\
\text { Albany }\end{array}$ & $\begin{array}{l}\text { NYC } 65 \\
\text { and over }\end{array}$ \\
\hline $0-1,000$ & 1.3 & 0.4 & 2.8 & 20.5 \\
\hline $1,001-2,000$ & 3.6 & 1.3 & 7.7 & 28.5 \\
\hline $2,001-3,000$. & 18.2 & 16.2 & 21.0 & 15.0 \\
\hline $3,001-4,000$ & 31.5 & 30.0 & 34.3 & 9.3 \\
\hline $4,001-5,000$ & 16.7 & 18.3 & 14.0 & 6.0 \\
\hline $5,001-6,000$ & 12.2 & 10.4 & 15.4 & 4.4 \\
\hline $6,001-7,000$ & 7.0 & 9.2 & 3.5 & 3.3 \\
\hline Over 7,000 & 9.4 & 14.2 & 1.4 & 13.0 \\
\hline Total & 100.0 & 100.0 & 100.0 & 100.0 \\
\hline
\end{tabular}


in New York City, the incomes of elderly people are extremely low. Approximately $64 \%$ are below $\$ 3,000$ per year.

Some $93 \%$ of the sample population surveyed were receiving social security payments, 408 were on pensions, 14.8 received SSI payments, 238 received interest, 88 had part-time jobs and 98 received food stamps.

The Lifeline Bill 7013-A included provisions for single-metered residences only. Table XII on the next page indicates the percent of elderly who own or rent their place of residence. Although not all renters live in master-metered apartments, this does give some indication of how many elderly residents would be eligible for the lifeline rate.

The Welfare Research Report found "these impacts (of rising energy costs) are found among both elderly homeowners and renters. Homeowners appear to be more severely impacted, however, because they must pay their own heating costs. Still the most important predictor of severity of impact appears to be income."

Approximately $68 \%$ of the renters surveyed reported a change in rent over the previous four years (1973-1977). while 328 reported no change, and $36 \%$ of those who had increases had been notified by their landlords that the increase had been due to fuel cost increases.

Need Assessment

The target group's consumption pattern for electricity, gas and oil was also presented in the Welfare Research Report. First, Table XIII provides a description of energy sources used for heating. 
TABLE XII

OWNER/RENTER STATUS OF SAMPLE POPULATION (BY $\%$.)

\begin{tabular}{|c|c|c|c|c|c|c|c|c|}
\hline \multirow[b]{2}{*}{. } & \multirow[b]{2}{*}{$\begin{array}{l}\text { Survey Sample } \\
\text { Combined }\end{array}$} & \multirow[b]{2}{*}{$\begin{array}{l}\text { Survey } \\
\text { NYC }\end{array}$} & \multirow[b]{2}{*}{$\begin{array}{l}\text { Survey } \\
\text { Albany }\end{array}$} & \multicolumn{2}{|c|}{$\begin{array}{l}\text { Population } \\
\text { Over } 65^{\star}\end{array}$} & \multicolumn{3}{|c|}{ Total Population* } \\
\hline & & & & NYC & Albany & NYC & A lbany & $\begin{array}{l}\text { New York } \\
\text { State }\end{array}$ \\
\hline Own & 37.6 & 28.0 & 53.7 & 25.2 & 47.5 & 23.6 & $40 . .5$ & 47.3 \\
\hline Rent & 62.4 & 72.0 & 46.3 & 74.8 & 52.5 & 76.4 & 59.5 & 52.7 \\
\hline TOTAI & 100.0 & 100.0 & 100.0 & .100 .0 & 100.0 & 100.0 & 100.0 & 100.0 \\
\hline
\end{tabular}

*Based on 1970 Census. All Occupied Housing Units (Source: NYS Division of Housing and Community Renewal).

Source: The Impact of Rising Energy Costs on the Elderly Poor in New York State (Albany, New York: Welfare Research, Inc.), 1978 (Table 2). 
TABLE XIII

ENERGY SOURCES USED FOR HEATING ${ }^{1}$

COMPARISON OF SURVEY SAMPLE OF LOW-INCOME ELDERLY WITH

STATE ENERGY OFFICE FIGURES FOR ALL SOCIOECONOM ZC GROUPS (BY PERCENT)

\begin{tabular}{lccccrr}
\hline & $\begin{array}{c}\text { Survey Sample } \\
\text { Combined } \\
\text { NYC \& Albany }\end{array}$ & $\begin{array}{c}\text { SEO } \\
\text { Statewide } \\
\text { Figures }\end{array}$ & $\begin{array}{c}\text { Survey } \\
\text { NYC } \\
\text { (Queens) }\end{array}$ & $\begin{array}{c}\text { Queens } \\
\text { County }\end{array}$ & $\begin{array}{c}\text { Survey } \\
\text { Albany }\end{array}$ & $\begin{array}{r}\text { Albany } \\
\text { County }\end{array}$ \\
\hline Electricity & 8.8 & 1.8 & 9.7 & 1.3 & 8.1 & 2.2 \\
Fuel Oil & 32.1 & 56.8 & 36.8 & 63.7 & 28.6 & 44.9 \\
Coal & 0.9 & 1.4 & 1.1 & 0.5 & 0.8 & 0.4 \\
Gas/Propane & 53.8 & 37.8 & 36.2 & 33.2 & 66.9 & 50.9 \\
Other & 2.5 & -- & 1.2 & -- & 3.3 & -- \\
\hline
\end{tabular}

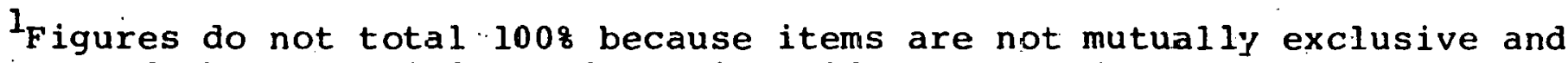
because some of those sampled could not identify source of heat.

${ }^{2}$ Source: New York State Energy Office.

Source: The Impact of Rising Energy Costs on the Elderly Poor in New York State (Albany, New York: Welfare. Research, Inc.), 1.978 (Table II). 
The study found,

- . that 988 of the sample who paid for electricity used. it for the following purposes: lighting (100\%), appliances (96\%), air conditioning (33\%), cooking (19\%) and heating (138). Ninety-two percent of those paying for gas used it for cooking and $40 \%$ for heating. Hot water was heated by gas or propane $(61 \%$ of those paying for hot water), oil (198), or electricity (138).

Some respondents may have associated supplemental electric space heaters with electric heat and therefore the figures for electric heating may be higher than expected, the study said.

Between 1973 and 1974 the estimated percentage of living costs spent on energy was $16.7 \%, 6$ whereas between 1976-77, 238 was spent on energy. According to the county Data Book, the average monthly Social Security Benefit in 1976 was $\$ 240$. A comparison of energy cost increases and increases in the Consumer Price Index was also made by Welfare Research (see Table XIV). It seems that $23 \%$ of a $\$ 240$ income would be significant, though the percent spent on electricity may not be as high.

Another study, done by Wayne Hoffman of the Urban Institute in Washington, D.C., found that in the 1976-1977 heating season, some $18 \%$ of elderly-headed poverty households in New York were in ."extreme need" or, spent more than $25 \%$ of their incomes on heating expenditures. ${ }^{7}$

What all of these figures indicate is that indeed the elderly of New York state have been hard hit by rising energy costs. A clear need for some kind of energy ing fuel.

${ }^{6} \mathrm{~A}$ mean of estimates for electricity, gas and heat-

7 Wayne L. Hoffman, Energy Need Among Low-Income Households: State Specific Estimates Using Several Alternative Measures (Washington, D.C.: The Urban Institute), 1979. 
COMPARISON OF LIVING COST INCREASES OVER ONE-YEAR

AND FOUR-YEAR PERIODS 1 . (AS PERCENTAGES)

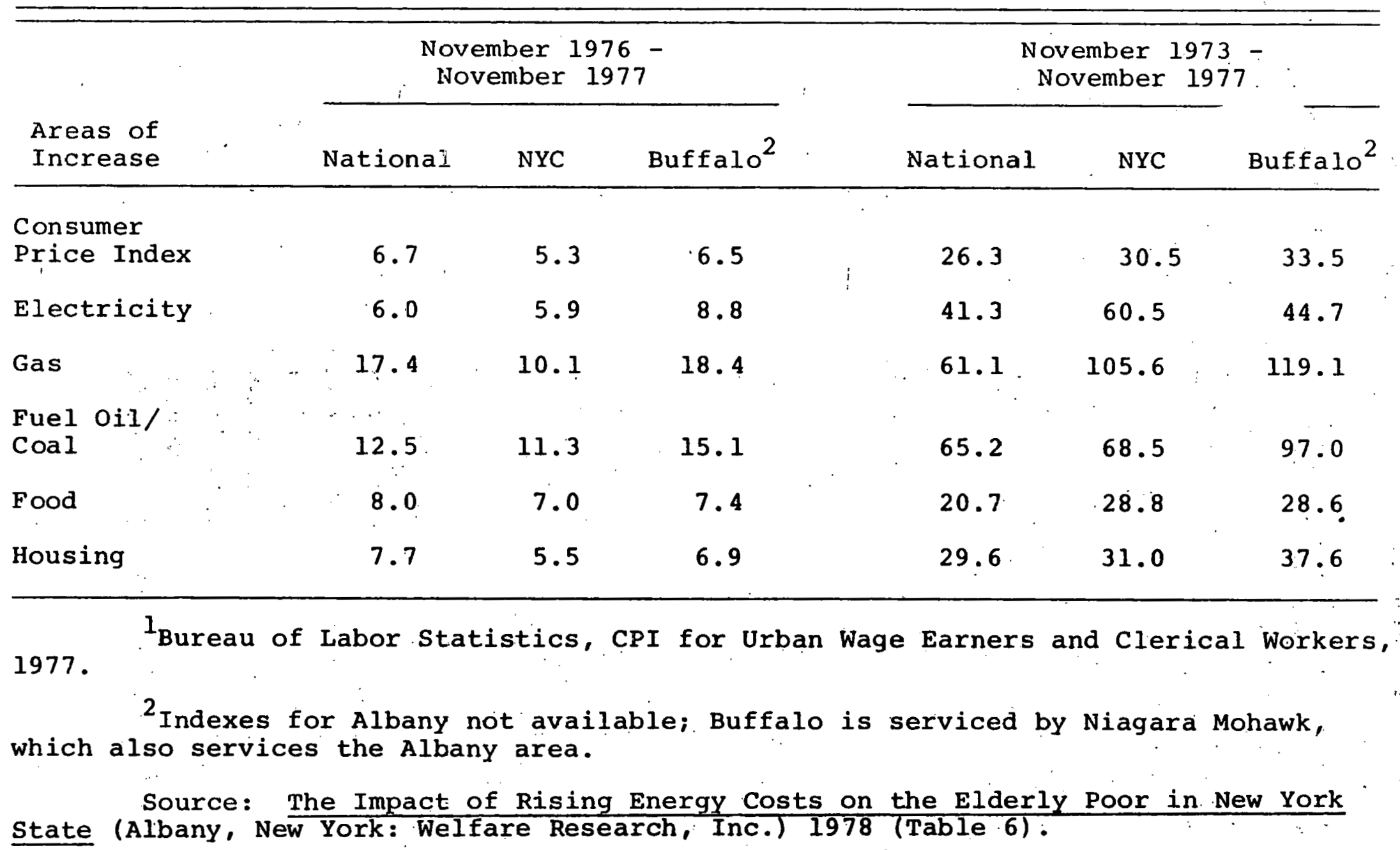


assistance has been demonstrated. As the Welfare Research study concluded:

The energy-related problems of the elderly poor in New York state are already severe, and will probably become worse. The elderly poor are experiencing extreme financial hardships as a result of increasing energy costs: Moreover, these hardships are negatively. impacting the quality of living of this group, causing negative changes in lifestyle, behavior, mood, health and safety.

\section{Targeting Effectiveness}

Exact figures on the monthly consumption of the elderly are not known, therefore, it is difficult to estimate the effectiveness of the $200 \mathrm{kwh}$ amount designated by SB 7013-A. It is thought, however, from the Impact of Rising Energy Costs on the Elderly, that consumption is quite low compared to that of other customers and, therefore, it is likely that a majority of elderly residents would benefit from the legislation.

Another factor which makes it difficult to project the targeting effectiveness of the bill is that administrative procedures for placing senior citizens on the rate were not mentioned in the legislation; nor were marketing procedures.

\section{Calculation of Benefit Levels}

studies which may have been conducted to project what the actual savings to elderly electric customers would be are not available. In order to calculate those savings, the average system rates for the state's utilities would have to be known (that is, what the lifeline rate for the first $200 \mathrm{kwh}$ would have been). Since they are not known, it is difficult to calculate benefit levels. 


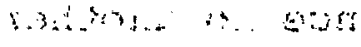

One rough calculation can be made, however, using. PULP's estimate of a $\$ 25$ million loss in. revenue as a. result of Lifeline Block Electric Rates. That revenue, distributed to the 600,000 potential beneficiaries of the legislation, results in a savings of approximately $\$ 41$ per customer per year, or, about $\$ 3.41$ per month. This is not a substantial part of an elderly person's income, but it may be significant to those who have. fixed, low-incomes.

\section{Revenue Recovery}

The revenue shortfall which would have resulted from the Lifeline Block Electric Rates would have been recovered by the utilities from a credit against the state gross receipts tax. It was estimated by legislative analysts at PULP that it would cost the state approximately $\$ 25$ million per year. As in the energy saving incentive plan, the state could have either absorbed the loss in tax revenue, or state taxes to some or all of the population could have been raised.

As to the direct effect on rates for non-lifeline customers, no significant, distortion of the pricing mechanism would have occurred. Rates would not have changed because of this legislation.

\section{Efficiency}

Data on marginal cost was not developed during legislative testimony. Since this was a targeted lifeline rate proposal, it may relate less to marginal cost than a non-targeted small-use rate or an inverted rate. There was no data developed on how it might have shifted or increased peak demand. 
In reference to another area of utility efficiency, there would have been administrative costs to the utility, the PSC and the state department of taxation for processing and approval of the tax credit. However, the bill never traveled far enough in the legislature for projections of that kind to be made.

\section{Conservation}

There were no projections or estimates made by intervenors which would have suggested that lower rates in the lifeline block would have led to increased consumption. In the theoretical sense, the usage study cited in this report (Impact of Rising Energy Costs on the Elderly) would suggest that consumption is inelastic to price, at least for low-income elderly. Those that were studied were using only the amounts of electricity needed for essentials. For that, they would have had to pay whatever was charged.

\section{Equity}

Data on electricity consumption by the elderly was not readily available, therefore, it is not known if this rate structure would have benefitted those for whom it was intended. Indications are that low-income elderly would have benefitted. Similarly! since the projected lifeline rate was unknown, it is difficult to discern whether or not the ability to pay criterion of equity would have been significantly addressed.

Lifeline, under this bili, would not have been associated with a recovery mechanism which would have led to sharp, discontinuous rate increases to other classes. Industrial and commercial rates would not have been affected, therefore, the good faith/reasonable expectation criterion of equity would not have been violated. 
In evaluating the quality of this proposal, it is important to note that Lifeline Bill 7013-A would have more closely resembled a social welfare program than an inverted rate or a non-targeted lifeline rate. The question to be answered was whether or not the state was willing to fund the program and, apparently, it was not. 


\section{RHODE ISLAND RESOLUTION 79-H 5770-A}

\section{Program Summary}

A Rhode Island Resolution introduced to the General Assembly in 1979 directed the Public Utilities Commission (PUC) to develop a.plan to provide free or reduced rates for the elderly, handicapped, seriously ill, or low-income persons.

The resolution.was very brief and required the PUC to:

-- Identify the above-defined group of persons residing , in the state;

-- Develop an "equitable plan" to provide "free or reduced rates or other modified service or benefits" for these persons.

Beyond these two provisions, the PUC was given no additional direction. They were, however, required to submit their plan to the General Assembly by March 1, 1980. 


\section{" Issue Development}

During a rate increase hearing filed by the Blackstone Valley Electric Company in late 1975 the Public Utilities Commission attempted to explore some of the more common alternative rate designs.. Expert, witnesses were called to testify and local public hearings were held by the PUC from December, 1975 through February, 1976., One authority on rate design, John.W. Wilson, spoke to the merits and drawbacks of inverted and lifeline rates as a means of redistributing. income. He stated, in part, that:

Under current regulatory requirements rate design must not be unduly or unjustly discrimlnatory nor detached from the cost of service. Income transfer programs are a separate consideration requiring social and political judgment as well as economic analysis emphasis added]. Using rate design as a means of altering income distribution would remove incomes policy from the social and political forum where these determinations are properly made, and where income redistribution decisions can be made independent of electric utility rate structures. . .

Mr. Wilson recommended that the Commission take an "initial step" by tilting rate increases away from the front blocks. This action, he felt, would be consistent with both the general philosophy of lifeline and with cost 
considerations, and would result in a general flattening of rates. Small users would benefit through smaller rate increases, and the momentum would increase for a uniform or flat energy charge.

He cautioned the Commission to be aware of the major difficulty in implementing lifeline rates as a direct low-income subsidization plan: "Commissions must still face the difficult task of designing plans so as to assure that those requiring such subsidies indeed receive them, and those consumers who do not require public income support do not qualify." I

The Coalition 'for Consumer Justice (CCJ) has been a prime mover in the push for subsidized, inverted and flat rates since its formation in 1974 : In addition to activity in energy-related matters; the "CJ is also active in many other areas of concern to middle and low-income consumers and the elderly. According to a spokesman, however, energy in general and utility rates in particular have consistently... been a top CCJ priority.

Acting as intervenors in the Blackstone Valley case, CCJ presented the only specific rate restructuring proposal heard by the Commission. This proposal was for a lifeline rate of $3 \xi$ per $k w h$ for the first $300 \mathrm{kwh} /$ month, with revenue deficiency to be recovered throughout the other blocks of the company's rates. 2 .

${ }^{1}$ see companion case study, Narragansett Electric Company SSI discount rate program, for expanded discussion of eligibility and targeting problems.

2 This proposal was very similar in profile to the one-year Demonstration Lifeline Program just getting started 
On the final day of testimony, a company witness offered an alternative to the CCJ lifeline proposal. He testified that revenue shift would be lessened if a fuel adjustment were included in the $34 / 300 \mathrm{kwh}$ lifeline block. Although impact assessment is to be more fully covered in a subsequent section of this report, it should be mentioned here that the PUC did declare itself unwilling to. "without a much more rigorous investigation and analysis [to] embrace such a sweeping shift in the rate structure."

In Order No. 9122, the Commission observed that most of the rate alternativce proposcd during the hearings , would not increase the bill of a residential consumer who used a minimal amount of electricity; therefore, Blackstone valley was ordered to "not increase the price of the first 300 kilowatt hours of electricity consumed each month by residential customers: . . ." .,

The PUC justified this price freeze of the initial residential block with the recognition that minimum residential users were:

carrying a heavy portion of the burden of supporting the company's revenue requirement . ... and the Commission will not add to the burden of these consumers during the interim period while a more complete restructuring of rates is investigated (Docket No. 1184-85).

The original freeze order was dated February 18 , 1976. This was followed by a supplementary order on March 2, 1976 which reaffirmed the freeze. Following this incorporating order, several Chambers of commerce and the

in 1976 in Maine; see Maine case study on the effects of a flat discounted rate, targeted to certain elderly low-income consumers. 
company.filed an appeal with the.state supreme court. This filing represented the emergence of another protagonist in the lifeline issue: the several area Chambers of Commerce. Rhode Island is one of a small number of states which does not appear to have a separate manufacturers' association; rather, the business interest is represented through active Chambers working together, and the Chambers' opposition to the BVE rate freeze exemplifies this relationship.

When the Commission agreed to, in effect, re-hear the Blackstone Valley rate, increase request, the supreme Court petitions were withdrawn. Blackstone had discovered errors in its calculations, and based on an opinion of the Attorney General, 3 the PUC agreed to treat the case as.a new request.

For approximately six weeks during the summer of 1976, a series of additional hearings resulted in a comprehensive investigation into Blackstone's rate structure.

Three area Chambers of Commerce appeared as inter-i.. venors protesting the rate freeze in this second series of hearings. These same Chambers (Blackstone Valley, Greater Woonsocket and Greater Providence) subsequently petitioned the Rhode Island supreme court to challenge the rate freeze. This petition followed a third affirmation (Docket No. 1232) of the residential rate freeze, issued by the PUC on September 1, 1976.

The three Chambers of Commerce contended that the exemption of the first $300 \mathrm{kwh}$ from the rate increase was

\footnotetext{
${ }^{3}$ Requested by the PUC.
} 
unreasonable and discriminatory, with no substantiating evidence in the record to support this exemption. This became their position throughout the rate freeze controversy. Chamber spokesmen have consistently opposed any policy which "uses utility rates as a social welfare subsidy."

During 1977 while this petition for review was awaiting the determination of the supreme Court, the khode Island General Assembly was also considering the lifeline question: a special legislative commission was formed to study the feasibility of establishing lifeline utility rates. Testimony was solicited during public hearings from individuals and organizations on both sides of the question. According to one newspaper account "the: Chambers and the Coalition have been at loggerheads over it [lifeline] for a long time--the Chambers' against it, the coalition for it." These organizations presented their respective positions to the Legislature, as they had to the PUC.

Subsequent to the legislative commission's study, language was incorporated into the Rhode Island General Laws which specifically permitted implementation of some form of rate break for elderly consumers. Inserted as a final paragraph in three separate sections of the Rhode Island General Laws that pertain to utilities was the following: "Nothing in this section nor any other provision of the Law shall be construed to prohibit the giving by any public utility, free or reduced rate service to any elderly person as defined by the division."

This law provides that free or reduced rates may be made available only to the elderly and only at the utility company's discretion. 
The Supreme Court granted the review and on January 5, 1979 returned the BVE freeze question to the Public Utility Commission for additional consideration. The court decided that PUC hearings had failed to set forth sufficient findings and evidentiary facts upon which the rate freeze had been based. Citing a previous Supreme Court decision, it was observed that the Commission had not been authorized. by the legislature to mandate or compel a utility company to provide reduced rates to senior citizens. "Under the statutes the initiative rests with the utility, and the Commission cannot, unless so authorized by the Legislature, compel its exercise (Rhode Island Consumers' Council v. Smith)."

The Court allowed that restructuring of electrical rates to eliminate or palliate past discrimination, or to improve allocation of cost of service would be appropriate objectives of the PUC; however, "In (this) case the commlssion could point to no evidence in the record which supports its determination and conclusion that residential users should be exempt as to the first $300 \mathrm{kwh}$ from the increased rate schedules approved."

The Court contrasted the Blackstone Valley freeze to a comparable rate freeze in effect in Massachusetts, saying that the Massachusetts rate was well-founded. The record showed residential Boston Edison customers were not responsible for a requested revenue hike that stemmed largely from the utility's construction program. 4

This rate freeze and its eventual disallowal,

${ }^{4}$ Refer to Boston Edison Residential Rate Freeze case study in this report for amplification. 
according to several major intervenors, represented the beginning of lifeline activities in Rhode Island. The Blackstone controversy identified the Coalition for Consumers Justice and the Chambers of Commerce as the central protagonists of the lifeline issue; and the case has become the springboard for subsequent legislative and regulatory activity.

\section{Additional Considerations}

Federal energy assistance programs are in operation through the state Energy Office. The state also has organized a strong senior citizens' club network. There are, however, no assistance programs in place tailored to or funded by the state alone. A Resolution calling for a feasibility study of energy stamp programs has been adopted by the Legislature, with a full report due by the end of the 1980 legislative session.

The CCJ, represented by its attorney intervenor Carl Freedman, has continued to pursue its active policy of intervention in all commission rate cases. Freedman explained, during a conversation in December, 1979, that the CCJ is presently waiting for a PUC decision regarding Newport, which is the smallest of the four investor-owned electric utilities in the state. The case has become "a. generic investigation of inverted rates." Eugene coyle, nationally recognized rate expert, presented "econamic, cost-based arguments in favor of implementing an inverter rate profile for the residential class."

Dr. Coyle summarizes his argument by saying: "More specifically, the evidence has shown that small residential users, because of their usage characteristics, are less costly to serve, display a higher rate of return and, hence, 
are deserving of a reduction in rates. . . ."

Similar justification has been presented by the CCJ in the Blackstone Valley case: CCJ is requesting that the present declining block structure be flattened. Freedman has explained that a tactical decision was made by CCJ to combine the lifeline issue with economic cost of service information. The arguments support: "a.flattening of the rates which would not be construed as a blatant social ratemaking gesture like a freeze or out-and-out lifeline and would benefit low users (Freedman conversation), many of whom are elderly and/or poor."

More recent information from a PUC staff contact is that a decision has been made by the PUC in favor of the inverted rate concept for the residential class: the rate will be constructed with a-sizable (.9k) differential-between the two blocks. 5 Actual rate schedules and other revenue questions have not yet been settled.

According to CCJ attorney Freedman, affirmative action by the Commission in the Newport (inverted) rate case would greatly strengthen CCJ's advocacy of rate flattening for the Blackstone Valley case.

${ }^{5}$ st block 0-300 kwh, 2nd block $301 \mathrm{kwh}$ and over. 


\section{The Governmental Process}

CCJ attorney Freedman claims authorship of three related lifeline bills which were introduced into the 1979 legislative session. Substantiating the need for three bills, he explained that an exception to discrimination was enacted into law in three separate sections of the Rhode Island General Laws; therefore, any amendments to this exception must also be addressed three times.

The 1979 trilogy of lifeline attempts were House Bill 5771-A, House Bill 5772-A and House Bill 5770-A (the topic legislation): All three bills were introduced in. General Assembly on February' 28, 1979 and were immediately referred to the House Committee on Corporations. The bills were reported out of the House Corporations Committee, hearings were held, and they subsequently passed the House on April 10, 1979. They were then referred to the senate Corporation Committee.

Senate hearings were held in early May for all three bills; HB 5771-A and 5772-A were not amended during the hearing process. Action was taken, however, by the Senate to alter the content of (topic legislation) $\mathrm{HB}$ 
5770-A. Substitute amendment "A" in the form of a Resolution was added to the Bill and its contents are discussed below. Sub-A, though never printed, was put to a roll call vote on May 4, the last day of the session. It passed unanimously $(62-0)$ and was sent to the House, with changed title, as the session closed. 6

The amendment provided that potential targeting was to be extended to include the handicapped, seriously ill, and low-income citizens as well as the elderly; administrative authority would shift from the utilities to the PUC; the Commission would be empowered to define eligibility requirements and to authorize the establishment of programs to be offered by regulated utilities.

According to Freedman, lifeline administrative authority should properly be placed with the Commission, and not with the utilities. The 1979 supreme Court decision struck down the Commission-mandated Blackstone Valley freeze partly because it ruled that the Commission had not been given the power to force utilities to implement programs. Many sources have pointed to this legislation as being a direct response to the BVE case, and the need for an expansion of power to the PUC.

This need for expansion of powers has also been observed by the Commission in comments made concerning Narragansett's proposal. 7 In the order establishing the

6 According to the Legislative Library, bills can be carried over to the following year's legislative docket if the legislation has not yet been approved, as is the case here. There has been no record of actual resubmission with the Legislature.

${ }^{7}$ See Narragansett SSI case study. 
SSI experiment, the PUC observed that no other utility had come forward to offer a plan, even though given specific permission to do so by the legislature. According to a PUC spokesman, lifeline legislation of the type described here could correct this situation, resulting in innovative rate programs. 


\section{Impact}

This legislation was chosen for study, in part, because of its general language. The legislation of other states discussed in this report was often aimed at setting up a program or specific plan, which then could generate specific analysis. This Rhode Island legislation takes an alternate approach--the general language of the bilis was considered implicitly necessary if the Public Utilities Commission were to be given the authority and the responsibility to create lifeline programs.

The "power to discriminate" can only be granted by the Legislature. This fact was upheld by the Rhode Island supreme Court, and is the purpose of this lifeline legislation.

Impact on Subsequent Legislation

These bills are part of the continuing process of the CCJ attempts to "promote change by precipitating that change." Their apparent failure has caused them to draft a 1980 trilogy of lifeline legislation, based on the problems encountered by this 1979 legislation. 
These new lifeline legislative proposals also call for the legislature to extend the authority of the Commission, but in a more specific direction: "This act would give the Public Utilities Commission the power to exempt the lowincome elderly citizens of Rhode Island from utility rate increases beyond rate leveis in effect at the time this act is passed." The author of both the 1979 and the 1980 versions, Carl Freedman, contends that 1980 lifeline legislation was a direct response to the 1979 bills, and a continuing response to the BVE rate freeze controversy.

\section{Impact on Target Population}

The Intended beneficiaries of 1979 lifeline legislation were to have been the handicapped, seriously ill and low-income citizens of Rhode Island. ${ }^{8}$

Based on 1975 Census estimates, the population of Rhode Island exhibits the following characteristics:

$\begin{array}{lll}\text { Elderly }-\therefore & \quad & 12.2 \% \\ \text { Low-Income } & & 11.9 \%\end{array}$

These figures translate into approximately 80,000 individuals with incomes at or below HEW poverty levels, and includes approximately 7,730 elderly households, ${ }^{9}$ plus an undeterminable number of "handicapped and seriously ill" individuals. 10

${ }^{8}$ Rhode Island General Laws already included the offering of "free or reduced rates" to all the elderly.

9 Wayne L. Hoffman, Energy Need Among Low-Income Households: State Specific Estimates Using Several Alternative Measures (Washington, D.C.: The Urban Institute), 1979.

${ }^{10}$ Definition of the terms "handicapped" and "seriously ill" was not provided by the legislation; therefore, meaningful estimates cannot be determined. 
The target population is essentially urban, largely concentrated around the Providence area and in smaller towns such as Cranston, Warwick and Woonsocket. Information is not readily available as to the living conditions of this target population, especially since it is only generally defined. It is known, however, that much of the elderly population lives with younger relatives, and many additional low-income persons of all ages live in master-metered public or private housing. 11

It is impossible to do more than speculate whether or not housing that was master-metered might have been included in a lifeline program. In the past, discount rates have been enjoyed only by individually-metered customers. 12

Need Assessment:

Statistics showing the energy consumption of the target population are not available. This group, however, as low-income consumers living in a cold climate is estimated to spend as much as 408 of their disposable income for home heating. 13 This "energy burden" is the result of poor housing stock and a general reliance on expensive, imported fuel oil as the primary home heating source.

Based on elderly SSI usage information of the Narragansett "A-65" program, which is aimed at a segment of this

${ }^{11}$ Phone conversation with' James Walsh, State Relations officer, Social Security Administration NE Region, January 28 , 1980 .

12 Blackstone Valley freeze and Narragansett "A-65" discounts, for example.

13 Source: New England Energy Congress Report, Somerville, MA, May 1979. 
target population, some assumptions can be made. Poor households who confine electricity usage to under $400 \mathrm{kwh}$ monthly would be billed approximately. $\$ 25.000^{14}$ An average winter fuel oil bill is estimated by the New England Energy Congress to be $\$ 1,100$ for the five-month heating season. Therefore, it may be stated that the target group may spend $\$ 1,225$ annually for electricity and fuel oil, which would equal 28.88 of a $\$ 4,250$ poverty single income.

According to the limited usaqe information that is available, $15300 \mathrm{kwh} / \mathrm{month}$ was judged by the Commission as adequate for small users. This figure, however, may not be adequate for low-income consumers who heat electrically or disabled consumers who require electric life-support devices. This is also below the average residential monthly consumption pegged at $466.5 \mathrm{kwh} .{ }^{16}$ No information was available, however, that indicated the number of kwh that might have been set at a discounted rate.

A low-income consumer using $400 \mathrm{kwh}$ per month, as an example, however, would be spending 78 of disposable income for electricity, with 8.48 of the utility bili representing the service charge. This does not appear to be a substantial amount compared to oil heating cost, but expenditures of this size may contribute to the "heat or eat" quandry faced. by many low-income persons.

14 Based on Narragansett's regular residential rate schedule (1979).

${ }^{15}$ Based on the Narragansett SSI program.

${ }^{16}$ Source: Edison Electric Institute, Statistical Yearbook, 1977. 


\section{Targeting Effectiveness}

It appears as though inexactitude concerning definition of this target population may have resulted in limited targeting effectiveness. It must be assumed, however, that precise definition of the eligible elderly, handicapped and low-income was to be the future responsibility of the commission.

\section{Calculation of Benefit Levels}

Per this legislation, the Commission was to be charged with the responsibility to develop an equitable plan that would provide discount rates to the target group. There are any number of variations which could have been employed by the PUC as it developed "an equitable plan," each generating different benefit levels. An attempt to determine actual benefit levels, therefore, would be purely speculative.

Pertinent to this discussion of potential benefit levels, however, is a brief description of the impact of alternative rates which are, or were, before this commission.

The Blackstone Valley rate freeze, the first such recognition in Rhode Island of the low-use/low-cost theory, resulted in a savings of approximately $\$ 1.50$ per month for customers using fewer than $300 \mathrm{kwh} /$ month. Actual subsidy amounts are not available but the business community voiced the belief that they were unfairly burdened and forced to subsidize residential customers.

The BVE rate request hearing begun by the PUC in January, 1980, will consider some of the energy and consumeroriented standards set by the National Energy Act of 1978 . According to the Providence Journal, if BVE is granted the 
full increase being sought, a household using an average 375 kwh/month of electricity would pay an additional $\$ 1.67$ on each bill. Hearings will run well into fall, speculated a CCJ spokesman, and lifeline proposals will definitely be a major part of the hearings.

Newport Electric inverted rate case: "A precedentsetting inverted rate under which residential customers of Newport Electric Corp. who use small amounts of electricity will pay slightly less per unit than higher-volume consumers was ordered February 20, 19.80 by the state PUC." According to the Providence Journal, under this new rate small users would save $\$ 1.83$ on $300 \mathrm{kwh} /$ month, even though the customer charge has been raised from $\$ 1.60$ to $\$ 2.80$. Actually, some savings will be realized for all consumption between 80 and $610 \mathrm{kwh} /$ month. So far, electric space heating and hot water rates have not been included.

\section{Revenue Recovery}

Since this legislation does not specify any actual rate structure, the topic of shortfall cannot be specifically addressed. The question of which class(es) will make up this undeterminable amount has also been left to the commission to answer.

\section{Revenue Effects on Subsidizers}

When questioned concerning lifeline legislative proposals, business leaders and chamber of conmerce spokesmen professed to having no definable position. The consensus of opinion appears to be that targeted rate programs implemented solely within a utility's residential class would have little impact upon the business community and therefore have evoked little response. 17

${ }^{17}$ See South Dakota lifeline case study for an opposite reaction. 
As can be expected, however, when rate programs impact on the business classes, positions coalesce. Spokesmen for the Rhode Island and Blackstone valley Chambers of Commerce as well as individual manufacturers have consistently opposed lifeline or inverted rate programs, such as the BVE rate freeze in 1976, and the flattened and inverted rate cases presently before the PUC.

These organizations contend that the adoption of lifeline would impact unfavorably by putting tax-paying, job-producing manufacturers at a competitive disadvantage. Manufacturers would face a severe economic burden if "rates were to be rigged by transferring the cost of residential service to the backs of business and industry." According to the National Association of Manufacturers, energy in the Northeast is already the most costly in the country. Industry believes lifeline tied to usage or subsidized by "all consumer classes" would exacerbate the energy problem and cause significant price distortions.

Such position statements, excerpted from local news reports and personal interviews, represent the nearly unanimous opposition of industry to inverted or lifeline rates. This opposition has apparently been fairly successful in blocking the CCJ proposals.

\section{Effects on Rate-Making Criteria}

This section addresses the issues of efficiency, conservation and equity, not from the more narrow perspective of the topic legislation but broady, from the perspective of all lifeline activities in Rhode Island.

Efficiency: This standard has been addressed primarily by the federally-funded BVE time-of-day study, 
ongoing now for two years. With a 3 to 1 cost ratio from peak to off-peak rates, and extensive usage data, 18 definite conclusions may be made concerning consumption patterns of individual consumers and of whole classes, and the effectiveness of price signaling as a device to reduce peak usage.

The BVE rate freeze of 1976 does not appear to have produced consumption/demand data. Looking to the future, the inverted rates recently ordered for Newport Electric and the possibility of flattened rates for BVE should, in time, yield interesting data that addresses the demand issue and speaks to the principles of marginal cost.

\section{Conservation}

Possible implications of the corollary effects of income on usage patterns are discussed in the Narragansett SSI case study of an actual lifeline rate program.

The RIPUC, as early as 1976,19 recognized that there existed within the residential class a sub-group of "small users," many of whom were elderly and/or low-income. "This sub-group was restricting or conserving usage to minimum levels, while "carrying a heavy portion of the burden of supporting the company's revenue requirement." 20 This statement was the original justification given by the Commission for freezing the cost of BVE's initial usage block. Legislative activities also are aimed at "giving a break" to elderly and low-income electric consumers, as has been described in this study.

${ }^{18}$ vid individual meters for each participant.

${ }^{19}$ Blackstone Valley rate freeze of the first 300 $\mathrm{kwh} /$ month of residential usage.

${ }^{20}$ RIPUC Order, Docket No. 1184-85. 
Implicit recognition is made, therefore, of the concept that those people at the bottom of the economic scale are less able to cope with spiraling utility costs and are already conserving, perhaps to the point of actual hardship. Legislative and commission actions imply at least a partial belief in the concept that reductions in cost will not significantly increase consumption. for such consumers because of the historically recognized inelasticity of this group.

Equity

The Iifeline controversy in Rhode Island, as elsewhere, appears to be polarized around the concept of how much will those eligible benefit, and how much will those ineligible suffer. An examination of the history of lifeline in the state reveals a growing momentum toward subsidized rates targeted to small users, not specifically the poor and/or elderly, with revenue recovery limited to the residential class only. Excessive energy costs and the resultant poor business climate have suppressed lifeline programs which call for the subsidization of certain residential customers by all other classes of customers.

The focus of lifeline has shifted away from a social policy aimed at "ameliorating past inequities" toward costbased programs to encourage conservation and discourage utility growth. Income transfer programs, such as energy stamps, are also being considered as one method of promoting equity of a more substantial nature both to the poor and to their subsidizers. 
THIS PAGE

\section{WAS INTENTIONALLY \\ LEFT BLANK}


SOUTH DAKOTA SENATE JOINT RESOLUTION 9

\section{Program Summary}

South Dakota Senate Joint Resolution (SJR) 9 would have established a lifeline amount of at least $500 \mathrm{kwh} /$ month $^{1}$ for all residential customers. Lost revenue was to be recovered, at least in part, through elimination of the declining block rate structure and elimination of promotional rates for large users.

The Public Utilities Commission (PUC) was to establish the actual size of the lifeline block, and in so doing was required to consider:

-- End-use (e.g., space and water heating, lighting, cooking and food refrigeration) in determining the size of the lifeline block;

-- Differences in energy needs between residential customers whose energy needs were met by electricity and by gas.

The rate finally set was:

$I_{\text {The resolution also included provisions for a life- }}$ line amount of natural gas in the amount of $200 \mathrm{ccf} / \mathrm{month}$. 
- To be "sufficiently low so as to require only. minimal financial outlay on the part of low-use customers";

-- To be significantly lower than current rates for the same level of usage;

-- Not to be increased by fuel adjustment charges, service charges, or other periodic charges in. greater proportion than any other user.

Any subsequent rate increases had to be decided based on the same set of considerations mentioned above.

Only large commercial and industrial users were spectfically exempted from the provision that "[n]o class of user. . . shall have a percentage increase imposed on their electric or gas rates which is greater than the average percentage increase imposed on any other class of user." 
Issue Development and The Governmental Process

The emergence of lifeline as an issue began from the widespread criticism of the traditional declining block structure which benefits large energy consumers by reducing rates as usage increases. As early as May, 1975, the South Dakota Public Utilities Commission (SDPUC) staff was directed to study the impact of a lifeline structure on the customers of Black Hills Power and Light Company and Northwestern Public Service Company. ${ }^{2}$

In 1978, the Association of Community Organizations for Reform Now (ACORN) developed the SUR 9 lifeline initiative which was later defeated in the November, 1978 election. Subsequent to the ACORN bill's defeat, SB 236 was proposed and, in summary, would have required the SDPUC to examine and report on the declining block rate structure, lifeline rates, peak load and off-peak pricing, time-of-day and seasonal pricing, interruptible load pricing, and single rate pricing where rates do not vary because of the classification of customers or amount of usage.

\section{${ }^{2}$ An Economic Interpretation of a lifeline Rate} Structure, presented to the South Dakota Public Utilities Commission by David E. Peterson, Staff Economist for the SDPUC. 
The principal actors surrounding the 1978 ACORN initiative include ACORN, the consumer group that fully. supported lifeline, and the South Dakota Rural Electric Association (SDREA) of nonregulated utilities, who opposed SJR 9. Interestingly enough, it was the nonregulated utilities who appeared to take the most active role in getting the ACORN initiative defeated and they would not. have been required to adopt a lifeline rate.

Need Assessment

The need for lifeline is described here by ACORN. ${ }^{3}$ According to ACORN, residents, family farms, and smali usage energy consumers were paying an average of $39 \%$ more per unit of gas and $33 \%$ more per unit of electricity than what large commercial or industrial users pay. The basic arguments for a lifeline rate by ACORN are contained in Senate Joint Resolution 9 and are presented as follows:

1. Light and heat are necessities of life and must be made available to all people at low cost for basic minimum quantities;

2. Present prices for residential customers for minimum quantities of energy are unjustifiably high;

3. Present discount rate structures for gas and electricity for large commercial and industrial users, encourage wastefulness and overconsumption of energy;

4. Wastefulness and overconsumption by large commercial and industrial users unduly drives up the cost of energy to all and depletes resources essential to humanity;

5. Customers who use large quantities of energy have the greatest opportunity for conservation of such energy.

${ }^{3}$ Lifeline is a Fair Deal, 1978, South Dakota ACORN. 
Opposition to Lifeline

The above arguments preserted by ACORN in SJR 9 apparently lacked sufficient detail, which in turn, led to several unresolved issues. These unresolved issues caused much opposition to the lifeline proposal. One organization in opposition to the reform which apparently played a major role in defeating the lifeline legislation was the SDREA of nonregulated utilities. Although the lifeline reform was directed only toward the regulated gas and electric utilities, the SDREA became involved in an extensive media campaign against the ACORN initiative. The massive efforts by these nonregulated utilities resulted, in part, from anticipation of lifeline rates being eventually applied to them as well.

The SDREA opposition to the 1978 lifeline measure was based on several factors. 4 First of all, the SDREA felt that utilities should not be involved in. what they considered welfare programs because there are governmental agencies who are especially equipped to handle.welfare processes. 5 Secondly, SJR 9 was intended to give aid to the elderly and the poor and yet there were no income or age requirements included. Thirdly, the SDREA believed that there was a false assumption by ACORN in that customers with low electricity consumption are poor and elderly and that high energy users are affluent. The SDREA found no empirical support for this notion. , Fourthly, the SDREA stated that no evidence was available to indicate that lifeline rates would encourage energy conservation and, in

\section{4 "SDREA Board Raps Lifeline Rates," South Dakota} Highliner (August 1978).

${ }^{5}$ Montana-Dakota Utilities Co., Docket Nos. F3240 and F3241, Testimony of Dr. Dale. E. Swan, October, 1978. 
fact, they felt that the $500 \mathrm{kwh}$ block minimum might not be enough electricity for large families who have poorly insulated houses. Finally, the SDREA opposed the ACORN initiative fearing that the higher costs of energy usage passed on to large industrial and commercial firms could mean higher costs of goods and services to all consumers, or, that industry would be forced to relocate outside of South Dakota. 6

Another influential organization in defeating the ACORN initiative was the East River Electric Power Cooperative (EREPC). The EREPC, was against the proposed lifeline reform primarily because the rate would be set below cost and would penalize those with greater energy requirements by passing on a higher cost to them. In short, they questioned the constitutionality of such a measure that could be discriminatory against certain classes.

${ }^{6}$ Also see East River Guardian, "Lifeline Measure Seeks Utility Cost Redistribution," Novenber; 1978, p. 15 . 


\section{Impact}

The intended beneficiaries of the South Dakoca

Senate Joint Resolution 9 were residential consumers who used $500 \mathrm{kwh}$ or less of electricity, and 200 ccf or less of.. natural gas.

In the state of South Dakota the population of 1975 was estimated to be 681,000 , with 674,000 projected for 1980.7 It is difficult to assess what the impact might have been on a targeted population because income, age, and : other necessary eligibility criteria were not developed. However, public assistance figures for 1976 indicate that some of the 3.7 .8 of AFDC recipients, 1.38 of SSI recipients and 38 of old Age Assistance recipients might have been eligible for a lifeline rate. Likewise, some portion of the 12.58 who make up the 65 and over group might have. benefited. However, it is not known how many of all these groups lived in noninvestor-owned utility service areas and

7U.S. Bureau or Census, Current Population Reports, Illustrative Projections of State Populations by Age, Race, and Sex 1975 to. 2000, issued March, 1979. Population Estimates and Projections, Series P-25, \#796. 
consequently, would not have fallen under the proposed lifeline rate category.

Need Assessment and Calculation of Benefit Levels

There is no data currently available on energy consumption patterns of the implied target groups in South Dakota. Consequently, income savings could not be determined. In fact, evidence from studies conducted elsewhere caused some to question the assumption that low-income and elderly persons use less energy than other residential consumers. For example, a Tennessee Valley Authority study found that the poor and elderly do not have uniformly high or low levels of electricity consumption. of the poor and elderly, 668 cooked electrically and 258 used electricity for space heating: Conversely, only 158 of the nonpoor did not use electricity for any of the above applications. Furthermore, in a sample of low and high income census tracts, it was found that consumers in low-income tracts used large amounts of electricity while persons of high income tracts used small amounts of electricity, which is contrary to the assumption behind the ACORN lifeline proposal. 8

In another study on consumption patterns compiled by the Minnesota Power and Light Co., statistics showed that users of $800 \mathrm{kwh}$ or more of electricity per month tend to have larger families, whether poor or not, and have a higher percentage of electric appliances. Farmers were also found to have higher than normal consumption patterns and could expect higher motor loads for material handling and higher refrigeration loads. 9

\footnotetext{
8 The South Dakota High L̈iner, September 1978.

9 Ibid.
} 


\section{Efficiency}

Dr. Dale E. Swan, an economist representing the Montana-Dakota utilities, gave testimony before the SDPUC and voiced the investor-owned utilities' opposition to the lifeline reform. It was Swan's opinion that if certain economic segments get relief from utility costs, then this would establish a precedent for other groups such as small businesses and churches to also request a subsidy. Swan urged the SDPUC to address five fundamental questions before considering any type of lifeline rate design, in order to resolve some of the arguments that had been presented. Any lifeline measure should include: 10

1. What income group. should receive the lifeline subsidy?

2. Who should bear the costs of providing this subsidy?

3. Will the proposed rate design accomplish the first two objectives?

4. Will the rate design cause minimal allocative efficiency distortions?

5. Is the rate design administratively feasible?

Furthermore, Swan recommended that instead of looking at the level of usage as the criterion for a lifeline rate, some need criterion such as family size, income and age should be considered. The allocation of the cost of subsidy should also be separate from usage levels and be based on ability to pay.

Conservation

There was serious doubt as to whether people would conserve any more with a lifeline rate structure than

${ }^{10}$ Docket Nos. F-3240 and F-3241, October, 1978. 
without one. A study which raises doubt as to the effectiveness of the proposed lifeline measure was conducted by the South Dakota State University. ${ }^{11}$ : This study showed that many poor families are large and live in poorly insulated, older homes. They further found that poorer people tend to spend most of their time at home in the evenings watching TV because they cannot afford more costly entertainment outside of the home. The more time spent at home, then, would lead to more energy consumption. Furthermore, the SDSU study found that the elderly require warmer homes than the average consumer and therefore would end up paying more for energy under lifeline rates. Conversely, the SDSU found that the more affluent elderly couple living in a small, well-insulated apartment or home, or who leave their homes in the winter for warmer climates, would use less energy and yet at the same time, would also be subsidized under the lifeline reform as constructed by ACORN.

This study also concluded that large government buildings would require large amounts of energy consumption and in order to cover these costs, taxes would have to be raised. The low-income and elderly then would end up spending more of their income in taxes, even though they might benefit from iffeline on their own utility consumption.

Equity and Cost Effectiveness

Position of the S.DPUC

The position of the SDPUC apparently reflected the strong opposition presented by the utilities, especially the noninvestor-owned utilities. The SDPUC opposed ACORN's lifeline reform based on the following reasons.

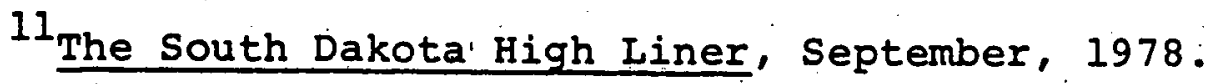


1. The 200 ccf amount of natural gas set for a lifeline block has the equivalent of approximately 5,862 kwh of electricity or roughly 10 times the energy subsidy provided for in the lifeline proposal;

2. The proposal was found to be inequitable bećause only investor-owned utility customers could benefit and not municipal or rural cooperatives' customers;

3. There had been no credible evidence supporting a correlation between energy usage and income, age, or family size of individual consumers or groups, or whether lifeline will help or hinder the lowincome and elderly of South Dakota;

4. There was no known basis to determine whether any conservation of energy could result if the lifeline proposal was enacted;

5. The SDPUC felt that industrial and commercial customers may end up moving out of state due to the higher utility costs that they must absorb as a result of the inverted lifeline structure;

6. The SDPUC was also concerned about the constitutionality of such a lifeline measure where it may deny various classes of customers due process of law.

The Position of ACORN

On the other hand, ACORN felt that SJR 9 was a very equitable program. ACORN reported that only 1.58 of industrial costs is for energy and that transportation, labor and materials make up the greatest percentage of their cost. Furthermore, energy costs can be deducted as a business expense, whereas residential customers cannot claim the same deduction. Meanwhile, residents pay an average of 108 of their income on energy with some senior citizens paying as much as 508 .

It should be noted that ACORN does not indicate where or how these figures were derived making it difficult to determine the reliability of the data. In fact, all of 
the data referred to in this report by either those for or against the ACORN initiative lacks sufficient information for assessing reliability. 
WEST VIRGINIA HOUSE BILI 943

\section{Prograin Summary}

The intent of West Virginia House Bill 943 was to "provide that residential customers of the electric utilities operating in the state shall pay the lowest unit rate charged to any residential eustomer for the first $500 \mathrm{kilo-}$ watt hours of electricity consumed per month ('Lifeline') and that such electric utilities shall employ a peak-load pricing schedule in their sales of electricity." Any shortfall in revenue was to be recovered "equitably from. all classes of energy use in a just and reasonable manner."

The rate established under this bill would have been applicable to all residential customers who maintained a residence in the state for at least 183 days of each year.

The specific method of setting the rate was not indicated; but minimum charges, service charges, or fuel adjustment charges could not be added to the bill of a residential customer for consumption within the lifeline block. 
The bill specified simply that peak rates were to - be higher than off-peak rates.

The Public Service Commission (PSC) was directed to conduct public hearings to review the lifeline rate and insure that it was adequate. Findings and recommendations of the PSC were to be presented to the legislature at the beginning of the regular session in 1979, and every three years thereafter. 


\section{Issue Development}

West Virginia has seen a myriad of bills introduced since 1975 which have attempted to provide assistance to low-income people in paying utility bills. HB 943 was one of many legislative attempts at lifeline initiated, for the most part, in response to consumer pressure. Senior citizens groups, particularly the council of senior west Virginians and the Coalition on Legislation for the Elderly, have led the push for lifeline in the state. However, none of their efforts has been successful.

\section{Previous/Subsequent Attempts}

Listed below are descriptions of some of the lifeline bills that have been considered in West Virginia since 1976 .

House Bill 1017, 1976: This bill would have established lifeline rates and amounts for all residential customers.

Senate Bill 259; 1978: This bill had several purposes related to utility regulation. Included were prohibiting utilities from. collecting increased rates under bond 
while action is pending on a rate case; requiring the Commission to hold hearings at night; prohibiting the fuel adjustment increase; requiring advertising to be paid from stockholders' dividends; requiring institution of peak load pricing by PSC; and requiring utilities to initiate lifeline rates for all residential customers with the PSC responsible for establishing lifeline amounts. The service charge on utility bills was to be eliminated and rates were not to exceed the system-wide average price per kilowatt as of January 1, 1977. The PSC was to report to the legislature on its review of lifeline every three years. Revenue was to be recovered from all classes.

Senate Bill 37, 1978: Senate Bill 37 would have provided for the establishment of a lifeline amount and $a$ lifeline rate not to exceed 34 per $\mathrm{kwh}$. Rates could be higher at times of peak demand. Service and minimum charges were prohibited. Revenue was to be recovered from all classes.

House Bill 1415, pending: Under this bill, utillties will be required to charge the lowest per kilowatt-hour cost then charged any of its residential customers for each of the first $300 \mathrm{kwh}$. Revenues are to be recovered from all classes.

The reasons for the defeat of the first three bills differ according to the opinions of the parties involved. Some say the bills were too comprehensive while others say they were too vague or that they did not allow the Public Service Commission enough flexibility in its ratemaking process. In addition to the intensive industrial lobbying against lifeline, the PSC has also opposed the issue. It has based its opposition on rate design studies to be discussed 
later in this case study.

Other Assistance Programs Considered

In 1978, a bill was passed that went considerably farther in the legislature than any of the lifeline bills. This legislation, H.B. 1176, would have provided a discount of $20 \%$ on gas and electricity bills of elderly, low-income customers. The bill was specific in its identification of a target group, delivery method and benefit levels. It passed the West Virginia House but was defeated in the Senate.

In the 1977-78 legislative session, thirteen energy-related bills were introduced in the House and the senate. Only two passed. One allowed for expansion of the Coal and Energy. Research Bureau at West Virginia University while the other established a Conservation Loan Fund. This fund provides low interest loans for low- and middle-income Fanilies for the purpose of weatherization.

\section{Actors}

\section{Consumers}

The Council of Senior West Virginians has established, as one of its priorities, "utility reform with special protection for small users and conservation incentives." The Council, a lobbying organization which represents the state's 300,000 elderly, has been a major proponent of lifeline legislation. The CSWV believes that west Virginia studies such as the Holmes report (to be discussed) confirm the fact that low-income people are small users of electricity and should be given lower rates.

\section{Utility Companies}

Monangahela Power Company, which serves the highly 
industrialized northern half of West Virginia offered three major objections to lifeline and inverted rates in a position paper on lifeline legislation. They were: (I) charges under a lifeline rate have no relation to cost. The low user is subsidized by the high user. (2) While an inverted rate may induce a few high-use customers to conserve, its effects on the larger number of low-use or medium-use customers is to encourage increased consumption. (3) Any cutback in consumption produced by inverted rates would, because of the higher tail-block rates, have a serious impact in its reduction of the company's revenues previously authorized by the Public Service Commission. Contacts at Appalachian Power Company indicate they share Monangahela's position.

\section{Manufacturers}

The West Virginia Manufacturers Association has opposed all lifeline proposals since the concept was first introduced, primarily because it believes such measures would drastically increase industrial production costs. West Virginia's manufacturing operations of primary metals, glass and chemicals are energy intensive industries, says the WVMA, that would be badly hurt by lifeline. Lifeline would come at a time when West virginia manufacturing employment is declining and competition is often just across the state line.

The manufacturers also contend that many low-income residential consumers are not low users of electricity and that rates to those living in master-metered public housing projects $^{1}$ would increase more than if there was no lifeline.

${ }^{1}$ Considered high volume users. 


\section{The Governmental Process}

The PSC

According to a January, 1976 article in the Charleston Gazette, the West Virginia Public Service Commission has testified against lifeline legislation for several reasons. First, it said its own studies indicate "there is no direct relationship between low incomes and low usage of electricity and this presents problems for the rate structure." Also, PSC Chairman Brooks said this type of ratemaking should be left to the PSC, not the legislature.

The studies the article referred to were a series of reports to the legislature from the PSC on various rate structures and pricing policies that began in late 1975. Four rate forms were considered: flat rates, inverted rates, discount or conservation rates, and the fuel adjustment surcharge (in relation to its flattening of rates).

While the PSC wanted to retain the option of imposing these rates, its conclusions favored a retention of traditional declining block rates. The PSC implied that this is the rate structure that is most cost-justified. It said that even the lowest rate in the high usage block is 
set high enough to cover variable unit costs and a portion of fixed costs, so that "a greater use of electricity at a higher load factor with no increase in peak demand will cover a greater portion of fixed costs."

The PSC also said declining blocks result in lower rates for all customers than flat or inverted rate forms, because sales in the high-use blocks recover portions of fixed costs that would otherwise be charged to low-use blocks.

Specifically in regard to lifeline, the PGC reports said that if the lifeline rate differential were large enough to be of significant benefit to low users, the reverue to be recovered from other customers would also be substantial. The effect would be another rate increase in addition to those that had already been imposed, or a revenue loss to the utility. On the latter option, the report said, since the PSC . . . is attempting to set rates of each West Virginia utility at the lowest possible, reasonable level of revenue requirements necessary for it to adequately serve its customers, we believe it would be an injustice if the electric utility was made to absorb this loss and may amount to confiscation.

These studies provided evidence to influence legislators against lifeline. Rate design studies conducted since 1975 as well as a report on the operation of the PSC conducted by a consulting firm were available. The firm's report was commissioned by the legislature and resulted in statutes revising the PSC's regulatory functions, such as requiring annual reports, and energy forecasting.

\section{The Legislature}

A consultant to the legislature, Alan Holmes, submitted a report to the subcommittee on Public Utility Regu- 
lation on December 7, 1976 , entitled A Study of Alternative Rate structures. The report,provided information on which" rate structure decisions could be made and was used in the legislature's consideration of lifeline proposals. Issues covered included the variables that affect electricity consumption, and an opinion survey on utility rates.

Details of the consumption patterns of West virginia's eustomers will be discussed later in this case study. One conclusion Holmes reached, however, was that the relationship between income and electricity usage was strong. Low-income customers, he found, were low usage customers. Despite this finding, lifeline legislation has been consistently defeated.

Holmes reported the results of the opinion survey by saying:

The people of the state of West Virginia do not favor reducing the burden of residential utility rates at the expense of an increase in the prices of goods and services caused by increased commercial and industrial rates; nor do they favor rate relief based on a lowincome criteria. However', they do favor utility rate relief to the elderly.

When asked if they favored reduced rates for fixedlow-income individuals, 568 of the survey respondents answered no, although $71-778$ responded favorably to the question of reduced rates for the elderly. Some 34-378 responded favorably to reducing residential rates and raising commercial and industrial rates. 


\section{Impact}

The Intended beneficiaries of the H.B. 943 were to be small-use residential customers.

In 1978, when the bill was proposed, the population of West Virginia was estimated to be $1,860,000$ (U.S. Bureau of Census). Some 225,000 lived in the service territory of Appalachian Power Company, while approximately 295,000 lived in the service territory of Monangahela Power Company. ${ }^{2}$

The population appears to have the following demographic characteristics:

-- Approximately 128 were elderly in 1978;

- In 1977, some 41,452 persons received supplemental Security Income:

- In 1976, some 74,406 persons received other public assistánce;

- The population is largely rural.

${ }^{2}$ Moody's Public Utility Manual. 
Approximately $68.9 \%$ of West Virginia's residents lived in owner-occupied homes. Although the exact number of residents living in master-metered homes is not known according to the County Data Book, there were no provisions to extend lifeline benefits to master-metered households in HB 943 .

Need Assessment

The target group which was supposed to benefit from HB 943, potentially all residential customers, exhibit consumption patterns documented in A Study of Alternative Rate Structures by Alan Holmes.

The Holmes report provided a detailed description of the consumption patterns of West Virginians. Holmes surveyed 1155 households in service territories of three electric utilities, Monangahela Power Company, Potomac Edison, and Applachian Power Company, and two gas companies. He found that 988 of the households with natural gas used gas as heating fuel.

Holmes also presented patterns of electricity consumption by income level.

That relationship between income and electric consumption is a strong one. Forty-one percent of the lowincome (less than $\$ 6,000$ ) households have consumption of $300 \mathrm{kwh} / \mathrm{month}$ or less, while only 98 of those households with more than $\$ 6,000$ a year income consume less than $300 \mathrm{kwh} /$ month. In addition, 698 of the low consumption householas (less than $300 \mathrm{kwh} /$ month) make less than $\$ 6,000$ per year while 228 of the high consumption households make $\$ 6,000$ or less.

Table XV is a reprint of Holmes' findings. The last three columns on the table were added by the authors of this report. 
TABLE XV

AVERAGE MONTHLY ELECTRICITY CONSUMPTION BY INCOME LEVELS

\begin{tabular}{|c|c|c|c|c|c|c|}
\hline Family Income & $\begin{array}{l}8 \text { of } \\
\text { Total }\end{array}$ & $\begin{array}{c}\text { Average } \\
\text { Monthly } \\
\text { Electric } \\
\text { Consumption } \\
\text { (kwh) }\end{array}$ & $\begin{array}{l}\text { Bill at } \\
\text { App. } \\
\text { Power Co. } \\
\text { Rates } \\
\text { (1978) }\end{array}$ & $\begin{array}{c}z \text { of } \\
\text { Monthly } \\
\text { Income }\end{array}$ & $\begin{array}{c}\text { Bill at } \\
\text { Monangahela } \\
\text { Power Co. } \\
\text { Rates } \\
\text { (1978) }\end{array}$ & $\begin{array}{c}\circ \text { of } \\
\text { Monthly } \\
\text { Income }\end{array}$ \\
\hline Less than $\$ 3,000$ & 12.8 & 490.7 & $\$ 15.83$ & 6.38 & $\$ 22.63$ & 9.18 \\
\hline$\$ 3,000-\$ 6,000$ & 18.6 & 514.7 & 16.20 & 3.28 & 23.49 & 4.78 \\
\hline$\$ 6,000-\$ 9,000$ & 17.1 & 708.5 & 18.91 & 2.58 & 29.73 & $4.0 \%$ \\
\hline$\$ 9,000-\$ 12,000$ & 15.3 & 835.3 & 20.69 & 2.18 & 33.73 & 3.48 \\
\hline$\$ 12,000-\$ 15,000$ & 12.4 & 880.6 & 21.32 & 1.28 & 35.16 & $2.8 \%$ \\
\hline$\$ 15,000-\$ 18,000$ & 7.2 & 954.5 & 22.36 & 1.58 & 39.05 & 2.68 \\
\hline$\$ 18,000-\$ 21,000$ & 7.7 & 946.6 & 22.25 & 1.38 & 37.24 & 2.18 \\
\hline$\$ 21,000-\$ 24,000$ & 2.3 & $1,358.7$ & 28.02 & 1.48 & 50.63 & 2.58 \\
\hline Over $\$ 24,000$ & 6.5 & $1,151,3$ & & & & \\
\hline
\end{tabular}

Source: "A Study of Alternative Utility Rate Structures," an Interim Report . presented to the Subcommittee on Public Utility Regulation, West Virginia, by Alan Holmes, December 7, 1976. 
From this table, it can be seen that energy use increases with income and the poor pay more of a percentage of their income on electricity bills. The poorest income group, those making under $\$ 3,000$, spend up to $9 \%$ of their monthly incomes on electricity bills alone. This seems to be a substantial percentage of disposable income.

Consumption patterns of elderly households ${ }^{3}$ were also described in Holmes' report. Some $40 \%$ had electricity use of less than $300 \mathrm{kwh} /$ month, compared to $12 \%$ of younger households. They generally lived in older homes and only 288 had medium to heavy electric appliance intensi.ty, compared to $58 \%$ of other households. Of the elderly households surveyed, $77 \%$ had incomes of less than $\$ 6,000$ per year, compared to $18 \%$ of other households. It is likely that many of these elderly households are on fixed incomes and would be significantly affected by any increase in energy costs.

\section{Targeting Effectiveness}

It appears that the majority of residential customers, including low-income customers would benefit from lifeline legislation.

Testimony recently presented during legislative hearings from Monangahela Power Company indicated that under a bill mandating a lifeline amount of $300 \mathrm{kwh}$, and inverted rates, the customer would not pay a total bill higher than his present bill until his consumption reached 2,866. kwh per month. Thus, it appears that a lifeline bill would certainly benefit the majority of residential customers. This finding is confirmed by the PSC.

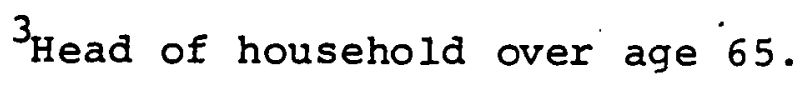


Residential usage and low-income usage from all. of West Virginia's electric companies was obtained from the Public Service Commission's 1975 rate studies, and is presented in Table XVI: Table XVI indicates that most lowand average-income usage is under $500 \mathrm{kwh}$ per month (the lifeline block which would have been required under HB 943):

Provisions do not exist in the bill for "marketing". of the rate.

\section{Calculation of Benefit Levels}

For House Bill 943, there were no studies done to project the actual reductions in the residential customer's bill. However, it is known that the bill directed the first $500 \mathrm{kwh}$ to be priced at the lowest unit cost charged any residential customer. According to the 1979 testimony. from Monangahela Power Company, that charge is now $2.956 \mathrm{c}$ per kwh. Benefit levels are calculated in Table XVII, by applying the 2.956 c charge to two levels of usage.

The same calculations can be made for the Appalachian Power Company. Applying the lowest per unit rate $(1.2 \xi)^{4}$ to the first $500 \mathrm{kwh}$, the bill resulting from lifeline is presented in Table XVIII.

While on a percentage-of-income basis, the benefits that would have been derived from West Virginia's proposed lifeline legislation seem small, they represent almost half of the present residential bills. This would be even more significant to the low-income and elderly consumer than to other residential customers.

\footnotetext{
${ }^{4} 1978$ residential rates.
} 
TABLE XVI

COMPARISON BETWEEN LOW INCOME CUSTOMER ANNUAL USAGE

AND TOTAL COMPANY ANNUAL RESIDENTIAL USAGE

\begin{tabular}{|c|c|c|c|c|c|c|c|}
\hline \multicolumn{4}{|c|}{ TOTAL RESIDENTIAL CUSTOMERS } & \multicolumn{3}{|c|}{ TOTAL LOW INCOME CUSTOMERS } & \\
\hline $\begin{array}{c}\text { Number } \\
\text { Customers } \\
\end{array}$ & $\begin{array}{c}\text { Kwh } \\
\text { Usage }\end{array}$ & $\begin{array}{l}\text { Annual } \\
\text { Average }\end{array}$ & $\begin{array}{l}\text { Monthly } \\
\text { Average }\end{array}$ & $\begin{array}{l}\text { Number } \\
\text { Custiomers } \\
\end{array}$ & $\begin{array}{c}\text { Kwh } \\
\text { Usage }\end{array}$ & $\begin{array}{l}\text { Annual } \\
\text { Average }\end{array}$ & $\begin{array}{l}\text { Monthly } \\
\text { Average }\end{array}$ \\
\hline
\end{tabular}

Black Diamond Power

United Light and Power

War Light and Power

Kimball Light and Power

Elkhorn Public Service Co.

Elk Power Co.

Union Power co.

Graig-Botetourt coop.

Harrison Rural Electric Assoc.

Monongahe la Power Co.

Potomac Edison Co.

Virginia Electric and Power $\infty$.

Wheeling Electric

New Martinsville Utilities

Appalachian Power

Preston County Ligh

Chesapeake light and Power

Standard Utility Service Corp.

Shenandoah Valley Electric Coop.

Philippi Municlpal Electric

1,382
995
475
511
240
906
1,341
218
3,317
222,602
47,965
16,684
29,915
1,390
293,406
2,862
1,133
1,170
1,186
1,258

$\begin{array}{rll}7,776,514 & 5,627 & 468.9 \\ 6,844,605 & 6,879 & 573.2 \\ 3,263,250 & 6,870 & 572.5 \\ 3,871,847 & 7,577 & 631.4 \\ 1,900,800 & 7,920 & 660.0 \\ 3,725,472 & 4,112 & 342.6 \\ 7,913,241 & 5,901 & 491.75 \\ 1,315,597 & 6,035 & 502.9 \\ 17,847,497 & 5,381 & 448.4 \\ 522,968,000 & 6,842 & 570.2 \\ 420,618,320 & 8,769 & 730.7 \\ 104,698,267 & 6,275 & 522.9 \\ 185,454,673 & 6,199 & 516.6 \\ 7,868,672 & 5,661 & 471.7 \\ 320,996,847 & 7,910 & 659.2 \\ 20,050,692 & 7,006 & 583.8 \\ 6,727,899 & 5,938 & 494.8 \\ 962,659 & 5,663 & 471.9 \\ 6,176,828 & 5,208 & 434.0 \\ 8,509,902 & 6,765 & 563.7\end{array}$

18
74
76
21
8
52
22
2
64
4,014
1,103
400
633
48
5,266
164,000
484,090
451.790
95,170
65,170
23,658
233,683
116,950
116,950
13,790
$1,795,655$
$27,172,560$
Note " $A$ "
Note "A"
Note "A"

Noto

9,111

759.2

545.2
5,945

$4.532 \quad 377.6$

8.225685 .4

685.4

$5,316 \quad 374.5$

$\begin{array}{ll}5,316 & 443.0 \\ 6,895 & 574.6\end{array}$

3,317
22,602

47,965

16,684

$22,947,329$

"A"

$5,717 \quad 476.4$

$420,618,320$

522.9

563.2

$\begin{array}{lll}6.489 & 374.1\end{array}$

$633 \quad 2,781,76$

$\begin{array}{ll}4.489 & 374.1 \\ 4.395 & 366.2\end{array}$

5,160 Note " $\theta$ "

$8,509,902 \cdot 6,765$

434.0
563.7

Note "A" - Company was deficlent in filing this information.

Note "B" - We sampled. 57.66 of the low incone group within

Appalachian Power Company 's service area and

Identifled 3,036 as Appalachian's customers. Using

this as a basis for computation, we assume that a

100 sample would result in customer and usage dato as indicated.

Sources West Virginla Public Service Commission 
TABLE XVII

MONANGAHELA POWER CO.

\begin{tabular}{ccccc}
\hline $\begin{array}{c}\text { Monthly } \\
\text { KWH Use }\end{array}$ & $\begin{array}{c}\text { Present } \\
\text { Typical Bill } \\
\text { Summer 1979* }\end{array}$ & Bill Under LI & Saving \\
\hline 250 & $\begin{array}{c}\$ 12.46 \\
\text { (base rate) }\end{array}$ & $\$ 7.39$ & $\$ 5.07$ \\
500 & 19.60 & 14.78 & & 4.82 \\
\hline
\end{tabular}

*Taken from National Association of Regulatory Utility Commissioners' Typical Residential Bills.

TABLE XVIII

APPALAC̣HIAN POWER CO.

\begin{tabular}{lcccr}
\hline $\begin{array}{c}\text { Monthly } \\
\text { KWH }\end{array}$ & Lifeline & Non-Lifeline & Saving \\
\hline 250 & $\$ 5.50$ & $\$ 11.50$ & $\$ 6.00$ \\
300 & 8.50 & & 16.00 & 7.50 \\
\hline
\end{tabular}

\section{Revenue Recovery}

The revenue shortfalls resulting from $\mathrm{HB} 943$ were to be recovered from all classes. A formula for this revenue recovery was not specified in the bill. West Virginia's manufacturers and the two major utilities, however, predicted that the impact of lifeline legislation would be very damaging to the state's economy.'For example:

The West Virginia Manufacturers Association projected a loss of jobs and a cutback in production by the state's energy intensive firms. It estimated the following 
hypothetical increases in energy costs to various firms as a result of a previously proposed bill, H.B. 1017:

-- Foote Mineral Company--an additional $\$ 1$ million in electricity costs;

-- Martin-Marietta Cement--\$344,000 increase;

-- Hurton Steel--\$2 million increase;

-- Alcan Aluminum-- $\$ 35,500$ increase;

-- Union Carbide--the Clarksburg plant produces graphite electrodes for use in electric arc steel production furnaces. Without electricity, graphite electrodes cannot be produced, therefore this industry would be significantly affected.

Monangahela Power Company projected revenue losses based on a $300 \mathrm{kwh}$ lifeline amount. Presumably, they would be less than the losses resulting from a bill containing provisions for a $500 \mathrm{kwh}$ amount as did $\mathrm{HB} 943$. The utility predicted that under the present rates, with the lowest unit rate (2.956 per kwh) charged to the lifeline block, 5 the loss to the company would be $\$ 11.6$ million.

Spreading such loss equally over all of the company's customers would require the addition to residential customers' bills of approximately 17.7 f for each 100 kwh used above 300 per month, and that same increase would be added to the entire kwh consumption of commercial and industrial customers since the lifeline rate would not be available to them.

On the other side of the coin, consumers have traditionally held that since a lifeline rate can be cost-justified on the basis of conservation of scarce fuel and the reduction in need for new capacity by the residential class, the lifeline customers are not being subsidized.

4.76 per kwh.

${ }^{5}$ This is 1.86 less than the average system rate of 
The PSC has held that if the lifeline rates were going to be "worth" it--i.e., a significant benefit to low users--a large lifeline block would have to be established and the differential between lifeline and average rates would have to be large. Therefore, a significant distortion of the present pricing mechanisms would occur.

\section{Efficiency}

The only discussion of marginal cost pricing in west Virginia as it related to lifeline rates was contained in the late 1975 PSC rate design studies. The PSC reported: Second.class ut1lity custoners should not be created just because they happen to come on line in an inflationary age . . the patent discrimination of this system [marginal cost pricing] plus the fact that system growth is based on projections of total integrated load estimated to occur several years in the future, cry out against the assignment of costs for growth of capacity to less than all of the customers of the utility.

In other words, the Commission did not accept the argument that the residential class contributes less to the need for new capacity and therefore should be given lower rates.

In regard to residential peak load pricing, the commission said it would be difficult to implement because of the high cost of installing residential time-of-day meters. In addition, it has not been shown, the report said, that such pricing reduces peak period use.

\section{Conservation}

The power companies and others opposing lifeline generally thought that this rate structure would lead to increased consumption in the initial block. Monangahela Power calculated how much more electricity could be consumed with lifeline than with present rates. For example, under 
pending legislation, a customer presently using $300 \mathrm{kwh}$ per month could increase usage to $406 \mathrm{kwh}$ per month with no increase in his present bill. Similarly, usage could be increased from 500 kwh to $595 \mathrm{kwh}$ with no increase in cost.

Despite these calculations, no hard evidence (attitude surveys, for example) was produced to indicate that these changes in consumption would occur. There was an even greater concern among lifeline opponents that increased conservation would occur in the higher usage blocks, thereby causing a loss in revenue to the utility.

\section{Equity}

It appears that those who were supposed to receive. a lifeline break as a result of $\mathrm{HB} 943$ would have recieved it. However, it was generally felt by all participants in lifeline hearings (with the exception of consumer groups) that a lifeline rate does not significantly address the ability to pay criterion. If it did, they say, the recovery mechanism would lead to sharp, discontinuous increases to other classes which would violate the good faith/reasonable expection criterion of equity. 


\section{THIS PAGE \\ WAS INTENTIONALLY \\ LEFT BLANK}




\section{WISCONSIN ASSEMBLY BILL 1250}

\section{Program Summary}

Wisconsin Assembly Bill 1250 required the Public Service Commission (PSC) to set lifeline amounts for electricity and gas. Rates were to be proposed by the participating utility companies. Revenue recovery was to be from all classes of customers, ${ }^{1}$ but no lost revenue could be recovered from bills for usage in the lifeline amounts.

All residential customers would have participated in the lifeline rate. Even if a customer's consumption exceeded the lifeline amount, only usage in excess of that amount would be billed at regular residential rates.

The participating utility companies were to file lifeline rate schedules that:

-- Reflected rates that did not exceed the lowest per unit charge to any nonresidential customers for the same billing period (including customer charges);

-- Set a lifeline rate that did not exceed rates in effect as of January 1, 1978;

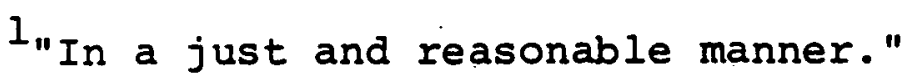


-- Set inverted nonlifeline residential rates, the highest of which could not exceed the average per unit charge assessed nonresidential customers that had the lowest average rate.

Service charges, minimum charges, or other periodic charges could not be added to rates charged for lifeline amounts.

Farm service customers could be exempted from the lifeline rate structure by the PSC.

The bill further required the PSC to issue information to consumers every six months. The information was to include an explanation of rate differentials and a discussion of the advantages of conservation. The Commission could order a utility to include this information as bili inserts, and the legislation required that the information be presented in "lay language."

Rate increases could be granted by the PSC only after the rates of all consumers had exceeded lifeline rates by 258 , and the 258 differential was to be maintained in the new rates. 


\section{Issue Development}

Much of the lifeline legislation in Wisconsin has been drafted with the help of a consumer group, Utility Consumers. United. A.B. 1250 in particular was introduced by Representative Becher and cosponsored by Senator Braun. Braun is primarily responsible for lifeline legislation that has been:introduced in the senate. The legislation was initiated in response to public pressure for utility rate reform to ease the burden of rising energy costs from residential consumers. More detailed assessments of consumer need will be given in later sections of this case study.

\section{Other Assistance Programs}

Wisconsin has been very active in rate reform and conservation. In addition to Commission activity, the legislature has enacted conservation measures as well.

In 1978, the Emergency Fuel and Assistance Program was passed. This provides loans of $\$ 200$ to low-income people who have been threatened with disconnection of service. The state of Wisconsin funds the program which is supplemented with 208 county matching funds. Also, in 1979 , 
the Citizens Utility Board, a state-funded consumer representative in utility rate cases, was established.

The comprehensive Gas Conservation Program was established in September of 1977. The PSC required all class A gas utility companies to develop a variety of conservation programs for consumer education, conservation loan financing and guarantees, household inspection and planning assistance. They were also required to develop a comprehensive conservation plan, including provisions for. utility rates.

\section{Aduitional Considerations}

The Wisconsin Public Service Commission, in order to cumply with its PURPA Section 114 requirements, has conducted an electricity usage survey of residential customers (the survey will also include questions on other subjects). Data will be analyzed through the month of June and Section 114 hearings will be held in the early part of July, $1980^{\circ}$.

\section{Actors}

\section{Consumer Groups}

Wisconsin lifeline legislation has had the support of the following groups:

Coalition of Wisconsin Aging Groups

Utility Consumers United

Dane County Community Action Commission

Juneau County Committee on Aging

Citizen/Labor Energy Coalition

Madison Terants Union

Wisconsin Environmental Decade

Project Involve

Wisconsin AFL-CIO 
These proponents advance the arguments that residential ratepayers who can no longer afford to pay their bills must be protected. According to a legislative analysis, "there are many low-income residents who, during the winter months, use 608 of their income to pay gas and electric bills."

The consumers cited many studies which indicate poor people use less electricity than those with higher incomes. Studies cited were from the ford Foundation, the Georgia Power Project, and the Washington Center for Metropolitan studies. Low-income people have low elasticities of demand and should not be "penalized" with higher charges for the lower-use blocks, they contend.

In addition to providing financial relief to residential customers, lifeline in wisconsin, according to consumer groups, would encourage conservation and discourage wasteful use of energy by large users. They argue that because of conservation impacts, the overall electric rates for all classes of customers will actualiy be lower with lifeline than without. Proponents had the supportive testimony of Walter Cavagnaro, Director of Utilities of the California Public Utilities Commission.

\section{Manufacturers}

The Wisconsin Manufacturers Association led the commercial and industrial customers' opposition to lifeline legislation. It cited PSC Chairman Cicchetti's testimony on the possible effects of lifeline as well as testimony from California PUC member William Symon. Symon said basically, that California's lifeline experiment was a failure because of the increase in costs to non-lifeline classes. Energy costs to the commercial and industrial classes had 
risen so much, according to Symon, that California's businesses were becoming noncompetitive and the costs of goods and services were rising rapidly.

Arguments of the manufacturers included:

-- Costs to serve the industrial class are lower than those for the residential classes;

-- If an increase in business rates occurs, the costs would simply be passed on to the consumer in the form of more expensive goods and services;

-- A lifeline rate constitutes a hidden tax to the commercial and industrial elasses;

-- The industrial and commercial classes had already had bigger increases than the residential class in recent cases. An added increase due to lifeline would be penalizing them unjustly;

-- Hospitals, schools and state agencies would be. "hurt" by lifeline as well as businesses;

-- There is a low correlation between income and usage;

-- Direct energy assistance grants to low-income customers would accomplish the same goal. without the side effects to higher energy users;

-- Legislators should not interfere with the ability of the PSC to desiqn rates.

Testifying against S.B. 122 were:

Charles Cicchetti, Madison, Public Service Commission

Paul E. Hassett, Milwaukee, for Wisconsin Manufacturers and Commerce

Melville G. Farber, Sheboygan, for Wisconsin Manufacturers and Commerce

Thomas J. Rutkowski, Milwaukee, for Wisconsin Manufacturers and Commerce

Gary A. McFarlane, Green Bay, for The Larsen Co.

John w. Kellogg, Racine, for Twin Disc, Inc. 
Gregory Krohn, state Energy office

W. W. Tolley, Port Edwards, for Wisconsin Paper Council, Nekoosa Papers, Inc. and WMC

John A. Glenz, Eau Claire, for Uniroyal, Inc.

John Heilala, Port Edwards, for BASF-Wyandotte

Edmund A. Kwaterski, Fond du Lac, for Wisconsin School Business officials 
The Governmental Process

Chronology--story of Defeat in Legislature

One of the first pieces of major lifeline legislation in Wisconsin was 1977 Senate Bill 718, the companion bill to $A B$ 1250. SB 718 contained the following provisions:

-- The Public Service Commission was to designate a lifeline amount of gas and electricity necessary to meet the basic needs of residential consumers for purposes of heating, lighting, cooking and food refrigeration;

-- Lifeline rates for gas and electricity were not to exceed the lowest rate charged to any customer during the same billing period and were not to exceed the relative rates in effect on January 1, 1978;

-- The Commission was not to approve an increase in the lifeline rate until all other rates exceeded the lifeline rate by $25 \%$ or more;

-- After the $25 \%$ differential was reached, the Commission could approve an increase in the lifeline rate but the lifeline rate had to be at least $25 \%$ less than regular rates;

-- Residents who used gas or electricity for agricultural purposes were to be excluded from the rate structure; 
-- Utilities could not supplement the rates for lifeline amounts with any minimum charge, service charge or other periodic charges to a residential customer;

-- If a revenue loss occurred, costs were to be recovered from all classes (excluding the lifeline class) in a "just and reasonable" manner;

-- At least once every six months, the PSC was to issue information to the public on the advantages of conservation under this rate structure;

-- A fine of not less than $\$ 25$ nor more than $\$ 100$ per day for each day of violation was specified for persons not complying with this law.

Neither AB 1250 nor SB 718 passed the 1977 legislature. According to the Legislative Reference Bureau in Wisconsin, the drafting request for 1979 Senate Bill 122 specified that it was to be drafted according to the contents of 718 , with the exception that there would be no sunset provisions.

Senate Bill 122 differed from 718 in that the rate differential between lifeline rates and average system rates was $50 \%$. It also required rates to be inverted. Provisions for extending lifeline allowances for lifetsupport services were also included.

Under this bill, periodic fixed charges were prohibited: they were to be converted into a per, unit charge and combined with the existing per unit charge. Wholesalers as well as agricultural users were exempted from the rate structure resulting from the bill.

Senate Bill 122 also required that gas and electric companies provide separate metering for each unit in apartment buildings and mobile homes built after January 1, 1980. 
The Public Service Commission was required to report on the implementation of lifeline annually.

On March 1, 19.79, the legislation was referred to the Committee on Insurance and Utilities and on April 19, 1979, a public hearing was held. Eventually, amendments were made to reinstitute the $25 \%$ rate differential and the public information requirement for PSC. Howeyer, no action was taken on SB 122 .

At the same time 122 was pending, an omnibus energy bill was introduced and voted on in the senate. In addition to provisions for numerous conservation measures--including recycling of waste oil, conservation education grants, preferential parking for car-poolers, weatherization loans-Senate Bill 500 contained a clause calling for inverted rates; the prohibition of periodic fixed charges; notices in bills on home energy audits or weatherization programs by the utility; and annual reports on the impact of lifeline rates from the PSC to the legislature.

What resulted from all this activity was this: the lifeline provisions in SB 500 were adopted on an experimental basis for a small number of customers in the service areas of the major utilities. It was essentially reduced to a "study" bill. This occurred in February of 1980. Senate Bill 122 or any other lifeline legislation will probably not be passed until the results of the experiments are known.

Projected Administrative Experience

In Wisconsin, a bill analysis includes projections of the costs of drafting and promulgating administrative rules for the state agency affected by the bill. For both 
$\mathrm{HB} 1250$ and SB 718, costs to the Public Service Commission were estimated to be $\$ 119,700 \mathrm{PRO}^{2}$ in 1978-79. A similar amount of revenue was to be collected from the utilities as PRO revenues. Continued administration was estimated at $\$ 92,600$ PRO and the requirement of two new staff positions during the 19.79-1981 biennium. Again, the PRO revenues would be collected from the utilities.

\section{Public Service Commission Activity}

Besides heavy lobbying by business and industry, one persuasive voice against lifeline was that of Wisconsin Public Service Commission Chairman Charles J. Cicchetti. In addition to many of the traditional antilifeline arguments, Cicchetti presented concerns that load management techniques adopted by the Commission may have been prohibited by a rate structure set by the legislature. These include time-of-day electric service and interruptible gas service. Cicchetti said basically, that the role of the government should be in the area of supplementing income, rather than utility rate design.

The Wisconsin PSC under Cicchetti has implemented several types of rate design changes over the last few years. For example, almost all the major utilities have flattened residential and other rates and have implemented seasonal differentials; Wisconsin Electric Power Company has instituted time-of-use rates for large residential users; Madison Gas Company has inverted residential rates; and Wisconsin Power and Light has a lifeline electric rate in effect. ${ }^{3}$

${ }^{2}$ Program revenue as contrasted to General Funds. "Program revenue" comes from sources other than tax dollars, e.g. admission fees to state parks.

${ }^{3}$ Whereby there is a two-step inverted block, then the schedules change to declining blocks. 
Thus, the issue of the role of the legislature in regard to rate-setting by the Commission was perhaps as much an issue as the lifeline concept.

ically: ${ }^{4}$

Cicchetti's arguments against lifeline were, bas-

1. The cost of supplying electricity varies by time of use and voltage, not volume of use, which does not affect unit cost;

2. Income levels and electricity use are not highly correlated. Therefore, the group which is supposed to benefit from lifeline may actually be subsidizing weal thy customers;

3. Lifeline may not encourage conservation, as has been suggested;

4. The fifty percent of Wisconsin's residents who heat with fuel oil and propane will not receive any aid under lifeline and thus will be discriminated against;

5. A hidden tax is being placed on industrial and commercial classes under lifeline.

4 Taken from April 19, 1979 testimony before the Senate Committee on Insurance and Utilities. 


\section{Impact}

The intended beneficiaries of A.B. 1250 were to be all residential customers.

Wisconsin has a population of $4,417,800 \quad(1975$ Bureau of Census estimates); served by six major electric utilities and many more rural cooperatives and municipally owned utilities.' The state's population appears to have the following demographic characteristics:

- Approximately 11.28 are elderly;

- Approximately 7.78 are low-income.

According to the County Data Book, in 1976, 714,892 of Wisconsin's residents received social security payments and 67,529 received supplemental security Income.

In 1970, the population was $66 \%$ urban and $68.9 \%$ lived in owner-occupied households. Provisions for extending lifeline benefits to master-metered households are not explicitly mentioned in A.B. 1250 .

\section{Need Assessment}

Data on energy consumption patterns of all of Wisconsin's residential custamers was generally not 
available. However, it is known, from legislative testimony, that approximately 508 of the population heat their homes with fuel oil and propane.

Approximately 318 of poverty households spent $25 \%$ or more of their incomes for heating expenditures during the 1977-78 winter season, and $72 \%$ spent $6 \%$ or more of their incomes on heating costs.

Rough calculations of percentage of incomes spent on. electricity costs can also be made.

From the National Association of Regulatory Utility Commissioners' (NARUC) data, typical June residential electric bills are known. These are presented in Table XIX and calculated as a percentage of a $\$ 15,000$ moderate income and a 1979 HEW poverty level income for a family of four. It would appear that electricity costs alone do not constitute a substantial part of disposable income.

\section{Targeting Effectiveness}

Because a specific lifeline kwh amount was not established by A.B. 1250, a projection of how successful lifeline rates would be in reaching their target population is hard to determine. Some hypothetical calculations need to be made.

Using data from NARUC, typical levels of summer usage (including air conditioning) are presented for the three major electric companies in wisconsin.

Assuming a typical lifeline allowance of either 250 or $500 \mathrm{kwh}$ per month, it would appear that the typical residential user would benefit. Even with air conditioning, 


\section{TABLE XIX}

PERCENTAGE OF INCOME SPENT ON ELECTRIC BILLS

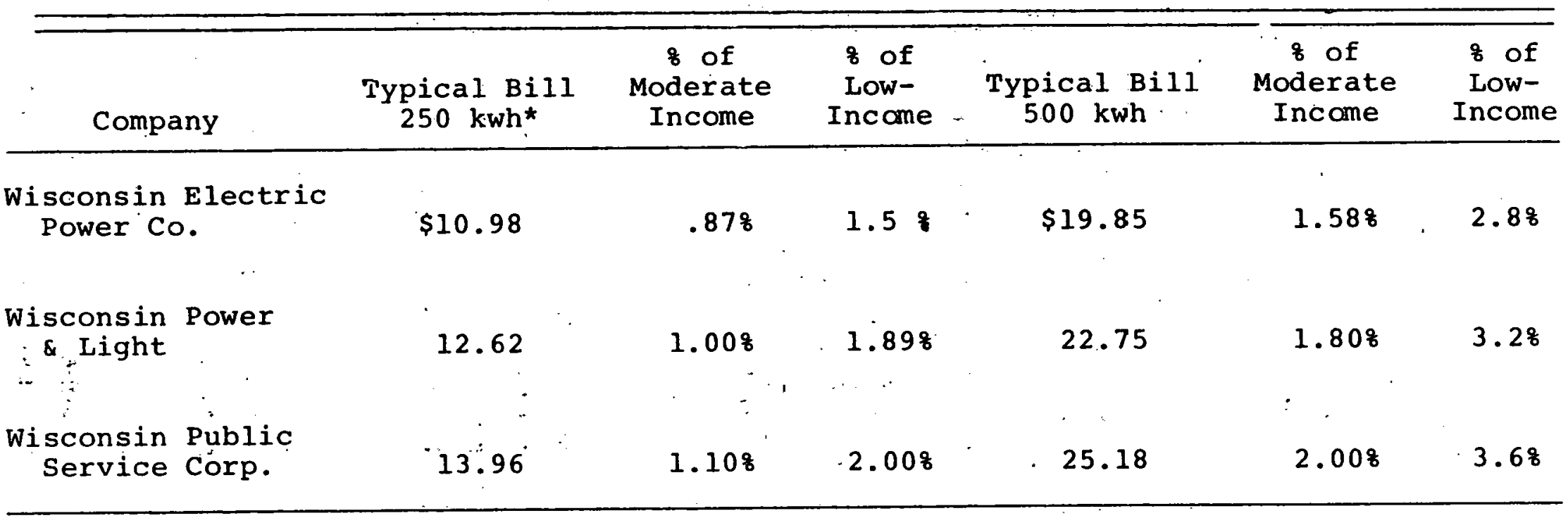

*Bills include fuel adjustment amount. 
typical monthly usage does not exceed $550 \mathrm{kwh}$. Since A.B. 1250 called for inverted rates, benefits would probably have extended beyond the basic allowance to some break-even level, beyond which one would pay more for electricity bilis with lifeline than without. It is quite possible, therefore, that both the average residential customer and the low-income. residential customer would benefit from the lifeline legislation.

TABLE XX

TYPICAL LEVELS OF SUMMER ELECTRIC USAGE

\begin{tabular}{lccc}
\hline \multicolumn{1}{c}{ Company } & June & July & August \\
\hline Wisconsin Power \& Light & $396 \mathrm{kwh}$ & $459 \mathrm{kwh}$ & $500 \mathrm{kwh}$ \\
$\begin{array}{l}\text { Wisconsin Public } \\
\text { Service Corporation }\end{array}$ & $486 \mathrm{kwh}$ & $450 \mathrm{kwh}$ & $462 \mathrm{kwh}$ \\
$\begin{array}{l}\text { Wisconsin Electric } \\
\text { Power Company }\end{array}$ & $536 \mathrm{kwh}$ & $490 \mathrm{kwh}$ & $\ldots$ \\
\hline
\end{tabular}

For a more detailed reference to low-income customers, usage by income level was determined in a study conducted by the wisconsin public service commission in conjunction with Wisconsin Power and Light and the Wisconsin Department of Revenue. Their findings were published in the December, 22, 1977 issue of Pubiic Utilities Fortnightly in an article entitled "Measuring the Impact of Residential Gas and Electric Rates," by Carol T. Everett and J. Robert Malko, and are presented in Table XXI. Table XXI illustrates that for people with incomes of $\$ 10,000$ or less, usage does not exceed $460 \mathrm{kwh}$ per month. It must be remembered that whether or not a lifeline rate would benefit low-income customers depends on the size of the lifeline block and the definition of low-income. 
TABLE XXI:

RELATIVE: FREQUENCY DISTRIBUTIONS OF ELECTRICITY USAGE BY WISCONSIN AND HOUSEHOLD INCOME LEVELS FOR ALL CITIES

SERVED BY WISCONSIN POWER AND LIGHT COMPANY

Part A-Relative frequency distributions of electricity usage by Wisconsin Income $\xi$ Level.

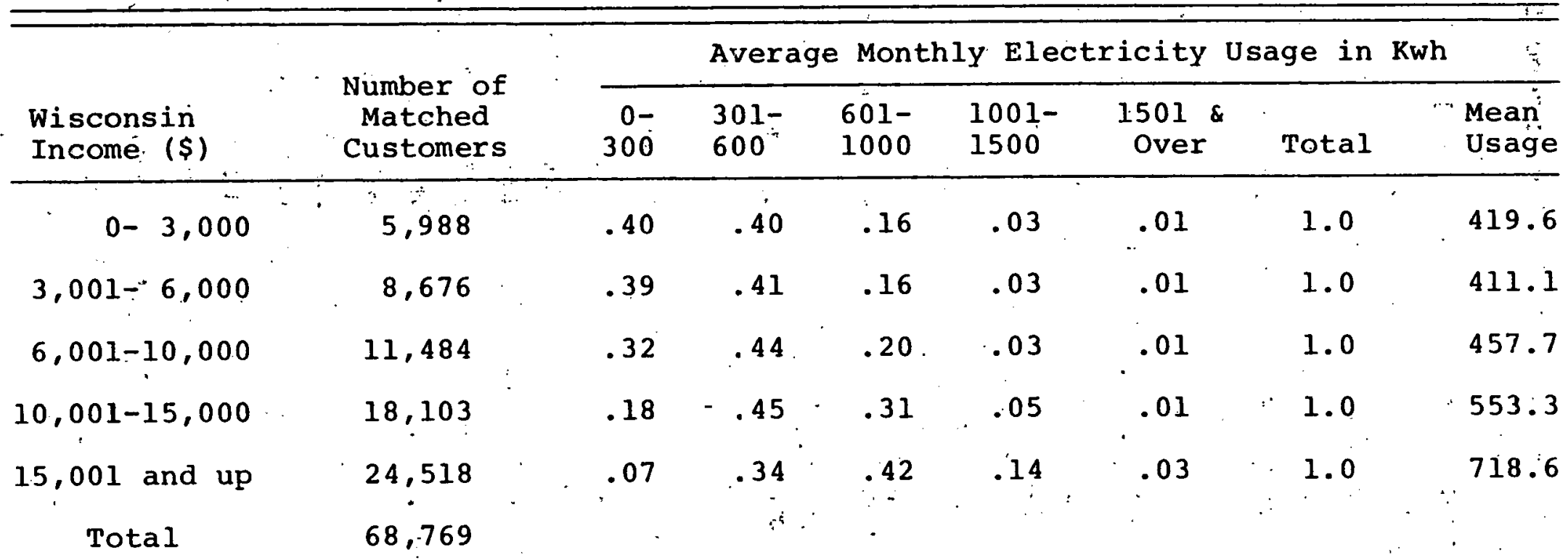


Part B--Relative frequency distributions of electricity usage by Household Income Level.

\begin{tabular}{|c|c|c|c|c|c|c|c|}
\hline \multirow[b]{2}{*}{$\begin{array}{l}\text { Household } \\
\text { Income (\$) }\end{array}$} & \multirow{2}{*}{$\begin{array}{l}\text { Number of } \\
\text { Matched } \\
\text { Customers }\end{array}$} & \multicolumn{3}{|c|}{ Average Monthly } & \multicolumn{3}{|c|}{ Electricity Usage in Kwh } \\
\hline & & 300 & $\begin{array}{l}301- \\
600\end{array}$ & $\begin{array}{l}601- \\
1000\end{array}$ & $\begin{array}{l}1000 \\
\text { Over }\end{array}$ & Total & $\begin{array}{l}\text { Mean } \\
\text { Usage }\end{array}$ \\
\hline $0-3,000$ & 2,640 & .61 & .29 & .08 & .02 & 1.0 & 303.1 \\
\hline $3,001-6,000$ & 7,927 & .51 & .39 & .09 & .01 & 1.0 & 338.3 \\
\hline $6,000-7,500$ & 1,610 & .31 & .49 & .19 & .01 & 1.0 & 433.7 \\
\hline Total & 12,177 & & & $\because$ & & & \\
\hline
\end{tabular}

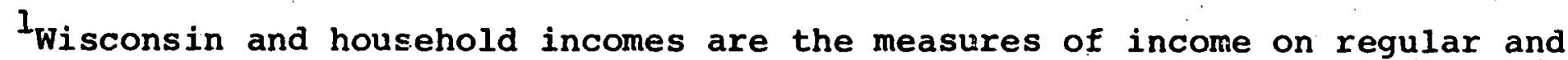
homestead returns, respectively. Only resident home owners and renters over the age of eighteen whose household income is less than $\$ 7,500$ per year and who do not receive either aid to families with dependent children or general relief are eligible for homestead tax credit relief.

${ }^{2}$ Row totals have been rounded to 1.0 .

${ }^{3}$ Greater disaggregation by income and usage levels is available. 
Targeting effectiveness may have been affected by provisions in A.B. 1250 to "market" the lifeline rate. Had lifeline legislation been passed, the PSC would have been directed to inform the public of the advantages of conserving electricity. Had the publicity campaign also included information on home weatherization and conservation loans, those low-income people who were large users of electricity. may have been able to reduce their usage and benefit from lifeline.

\section{Calculation of Benefit Levels}

There are no studies readily available which project the savings that would have accrued to residential customers as a result of A.B. 1250. Theoretically, however, the assumption can be made that savings to residential customers would have approximated revenue shortfall.

The method some of the intervenors apparently used in calculating revenue shortfalls was to take the average increase per year in customer costs and assume that an increase would not be applied to the lifeline class of customers. The lifeline allowance would be projected at 300 or $500 \mathrm{kwh}$ per month, since that seems to be standard for lifeline proposals.

The Wisconsin Manufacturers Association, for example, projected a savings of .375k per kwh to lifeline customers for the first year of enactment. 5 This would equal $\$ 1.12$ for $300 \mathrm{kwh}$ of use and $\$ 1.87$ for $500 \mathrm{kwh}$ of use. In the second year, the savings would be $\$ 1.68$ and $\$ 2.80$,

${ }^{5}$ These estimates are taken from da'ta contained in the "Revenue Recovery" section. 
respectively or $.56 \%$ per $\mathrm{kwh}$. This does not appear to represent a substantial percentage of a household income.

The WMA also predicted that after the first two years lifeline would be in effect, revenues collected from the residential class would decrease by almost $15 \%$.

\section{Revenue Recovery}

The revenue shortfalls resulting from A.B. 1250 were to be recovered from all classes of customers in a "just and reasonable manner.;"

Shortfalls were projected by various opponents of Iifeline. Many of them used figures provided by Wisconsin Power and Light. A few of these estimates of the impact of a lifeline bill on the commercial and industrial classes are presented in the tables on the following pages. It must be noted that these projections were made without knowledge of what the actual lifeline amounts or rates were going to be.

Assumptions for Testimony from the Eau Claire Uniroyal Plant (Table XXIV)

1. Lifeline quantity of $300 \mathrm{kwh}$ per month per residential customer;

2. Not knowing what the rate of inversion will be, the redistribution of lost revenues will be spread evenly over the other classes of customers on a per kwh basis;

3. That the normal increase in customer costs without SB 122 would be $7 \%$ per year in the Northern States Power service area of 'Wisconsin;

4. That the yearly kwh usage of the Uniroyal Eau Claire Plant will remain constant through.1984 $(85,000,000 \mathrm{kwh})$. 
TABLE XXII

ESTIMATED SHORTFALL-UNIROYAL

\begin{tabular}{|c|c|c|c|c|c|c|c|c|c|}
\hline \multirow[b]{2}{*}{ Year } & \multicolumn{3}{|c|}{ Without Lifeline } & \multirow{2}{*}{$\frac{\text { With }}{\text { \&/kwh }}$} & $3.00 \mathrm{kwh}$ & Lifeline & \multicolumn{2}{|c|}{ with $500 . \mathrm{kwh}$} & \multirow{2}{*}{$\frac{\text { lifeline }}{\text { \$/Year }}$} \\
\hline & c/kwh & 8 Incr. & \$/Year & & \&Incr. & \$/Year & c/kwh & sIncr. & \\
\hline 1980 & 2.3 & - & $1,951,000$ & 2.48 & 7.8 & $\$ 2,108,000$ & 2.52 & 9.1 & $\$ 2,142,000$ \\
\hline 1981. & 2.46 & 7.0 & $2,091,000$ & 2.69 & 16.9 & $2,287, .000$ & 2.74 & 19.1 & $2,328,000$ \\
\hline 1982 & 2.63 & 14.4 & $2,236,000$ & 2.90 & 26.3 & $2,465,000$ & 2.99 & 30.0 & $2,542,000$ \\
\hline 1983 & 2.82 & 22.6 & $2,397,000$ & 3.14 & 36.6 & $2,669,000$ & 3.26 & 41.6 & $-2,768,000$ \\
\hline 1984 & 3.02 & 31.3 & $2,567,000$ & 3.39 & 47.2 & $2,882,000$ & 3.54 & 53.8 & $3,007,000$ \\
\hline \multirow{2}{*}{\multicolumn{4}{|c|}{$\begin{array}{l}\text { Normal electricity } \\
\text { costs to plant }-\$ 11,242,000\end{array}$}} & \multicolumn{3}{|r|}{$\$ 12,411,000$} & \multicolumn{3}{|r|}{$\$ 12,787,000$} \\
\hline & & & & \multicolumn{2}{|c|}{$\$ 1,169,000$} & increase & \multicolumn{2}{|c|}{$\$ 1,545,000$} & 0 increase \\
\hline
\end{tabular}

1979. Source: John Glenz, Engineer at Eau Claire at Uniroyal Tire Plant, April 17, Note: \& Increase is a cumulative increase with 1980 as the base. 
TABLE XXIII

WISCONSIN POWER AND LIGHT ESTIMATES OF S.B. 122

(LIFELINE RATE) IMPACT ON INDUSTRIAL CUSTOMERS

\begin{tabular}{|c|c|c|c|c|}
\hline \multirow[b]{3}{*}{ Year } & \multicolumn{4}{|c|}{ Electric--Time-of-Day Customer (over $200 \mathrm{kw}$ ) } \\
\hline & \multicolumn{2}{|c|}{ Without Lifeline } & \multicolumn{2}{|c|}{ With Eifeline } \\
\hline & Avg: $\varphi / k w h$ & $\begin{array}{c}8 \text { Increase } \\
\text { Rate Increases }\end{array}$ & Avg. \&/kwh & $\begin{array}{l}8 \text { Increase } \\
\text { Rate Increase } \\
\text { and Lifeline }\end{array}$ \\
\hline 1980 (base) & 3.4 & & 3.8 & 12 \\
\hline 1981 & 3.7 & 9 & 4.3 & 26 \\
\hline 1982 & 4.1 & 21 & 4.8 & 41 \\
\hline 1983 & 4.5 & 32 & 5.4 & 59 \\
\hline
\end{tabular}

RESULT: After 4 years, assuming rate increases of $10 \%$ per year, the typical time-of-day customer is paying approximately $27 \%$ more due to the lifeline rate.

Testimony from the Wisconsin Manufacturers Association. 
TABLE XXIV

WISCONSIN POWER AND LIGHT ESTIMATES OF S.B. 122

(LIFELINE RATE) IMPACT ON COMMERCIAL CUSTOMERS

\begin{tabular}{|c|c|c|c|c|c|c|c|c|c|c|}
\hline \multirow[b]{3}{*}{ Year } & \multicolumn{10}{|c|}{ Electric--Small Commercial (store) } \\
\hline & \multicolumn{5}{|c|}{ Without Lifeline } & \multicolumn{5}{|c|}{ With Lifeline } \\
\hline & Avg. & $\phi / k w h$ & $\begin{array}{r}8 \\
\text { Rat }\end{array}$ & $\begin{array}{l}\text { Increa } \\
\text { Incre }\end{array}$ & $\begin{array}{l}\text { ase } \\
\text { eases }\end{array}$ & Avg. & c/kwh & $\begin{array}{l}8 \text { I } \\
\text { Rate } \\
\text { and }\end{array}$ & $\begin{array}{l}\text { Encre } \\
\text { Inc } \\
\text { Life }\end{array}$ & $\begin{array}{l}\text { se } \\
\text { ease } \\
\text { ine }\end{array}$ \\
\hline 1980 (base) & & 1 & \multirow{2}{*}{\multicolumn{3}{|c|}{$=$}} & \multicolumn{2}{|c|}{5.5} & \multicolumn{3}{|c|}{8} \\
\hline 1981 & & 6. & & & & \multicolumn{2}{|c|}{6.1} & \multicolumn{3}{|c|}{20} \\
\hline 1982 & & 1 & \multicolumn{3}{|c|}{20} & \multicolumn{2}{|c|}{6.9} & \multicolumn{3}{|c|}{35} \\
\hline 1983 & & 7 & \multicolumn{3}{|c|}{31} & \multicolumn{2}{|c|}{.7 .7} & \multicolumn{3}{|c|}{51} \\
\hline
\end{tabular}

RESULT: After 4 years; assuming rate increases of $10 \%$ per year, the typical time-of-day customer is paying approximately $20 \%$ more due to the lifeline rate.

Taken from testimony from Wisconsin Manufacturers Association. 
Lifeline opponents felt a significant distortion of present pricing mechanisms would occur from such a rate. The intervenors also said that the added increase in energy costs to Wisconsin's commercial and industrial customers would result in a potential loss of jobs, a cutback in plant expansion and a loss of a competitive business climate.

Utility Consumers United refuted these charges by saying that electricity represents a very small percentage of industrial operating costs. It argued that for 9 out of 10 industries with the largest energy consumption in wisconsin, the electricity was 38 of all their material costs in $1976 .^{6}$ Furthermore, UCU said lifeline would rcsult in an increase in electric rates of only .5\% for most wisconsin industries and $1 \%$ for the primary metals industry. The group contended that electricity costs were not a major factor in plant relocation or expansion.

\section{Efficiency}

Marginal cost was not specifically mentioned in the lifeline debate. However, the PSC did present some of its philosophy in regard to utility pricing.

The Public Service Commission said it advocated rates based on cost-of-service. It believes a fixed minimum monthly charge should be included because there are costs that are fixed and independent of usage. ${ }^{7}$

The PSC also predicted that load-balancing rate

${ }^{6}$ Milwaukee Journal, July 22, 1979.

${ }^{7}$ Periodic fixed charges are prohibited under lifeline legislation. 
concepts, such as time-of-day rates, would have to be abandoned if an inverted rate structure-were to be implemented. The reasoning behind this statement is unknown. The lifeline bills mentioned here do not specifically prohibit peak load pricing. Perhaps time-of-day rates would affect the provision of the bills which call for a differential of either $25 \%$ or 508 between the average system rate and lifeline rates. This could cause non-lifeline rates including peak rates, to have excessive increases.

Specific projections of changes in system or peak demand are not available. Manufacturers have expressed a concern, however, that large rate increases could trigger a switch to alternate fuels, which could have implications for future plant capacity and peak demand.

\section{Conservation}

No hard evidence was available which would have indicated whether lifeline would lead to an increase or decrease in consumption of electricity; however, many opinions were offered during legislative debates. These opinions were typical of lifeline proponents and opponents. The proponents felt consumption would be reduced in the higher use blocks and consequently, energy would be conserved. The opponents felt wasteful use of energy in the lower usage blocks would be encouraged.

Equity.

Lifeline in the Wisconsin legislature never really progressed to the point where strong data on the anticipated impact of the program could be generated. If it can be assumed that the lifeline block would be 300 or $500 \mathrm{kwh}$ per month, then, based on average usage figures, the typical residential customer would benefit from the legislation. 
Based on the Commission's low-income usage study; the lowincome household would also benefit from a lifeline or inverted rate structure. How large the benefit would be or how significantly the ability to pay criterion of equity. would be addressed is impossible to determine. It is also a matter of opinion whether the revenue recovery mechanism would violate the good faith/reasonable expectation criterion of equity. The debate in the wisconsin legislature has essentially been over the concept of lifeline and who should impose it, rather than over specifics of the bill itself. 


\section{UNITED STATES}

DEPARTMENT OF ENERGY

WASHINGTON, D.C. 20585

OFFICIAL BUSINESS

PENALTY FOR PRIVATE USE, $\$ 300$

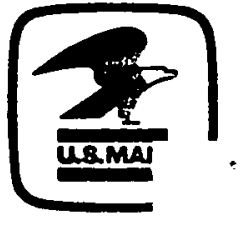

